\title{
COUNTERMAJORITARIAN HERO OR ZERO? RETHINKING THE WARREN COURT'S ROLE IN THE CRIMINAL PROCEDURE REVOLUTION
}

\author{
CORINNA BARRETT LAIN ${ }^{\dagger}$
}

Our courts were entrusted with the responsibility of judicial review, in large part, to protect individuals and minorities in their fundamental rights against abridgement by both government and majorities.'

When we think about judicial review, we tend to envision the Supreme Court as a "countermajoritarian hero,"” protector of minorities from tyrannical majority rule. The Supreme Court itself has long promoted this image, most famously in a 1938 footnote $^{3}$ but elsewhere

${ }^{\dagger}$ Assistant Professor of Law, University of Richmond School of Law; J.D., University of Virginia, 1996. Like the Beatles, I get by with a little help from my friends. Special thanks to Ron Bacigal, Michael Klarman, Earl Dudley, Michael Allan Wolf, Carl Tobias, John Nowak, Warren Billings, Emmy Paulette Reeves, Jim Gibson, John Douglass, and John Lain for their substantive input and editorial comments. Thanks also to Stacy Reed, Dan Petouvis, and Anne Major for their research assistance and to Richmond's talented library staff for helping me locate several period documents. I am likewise grateful for a research grant provided by Hunton \& Williams, P.C. Finally, I credit Jessica Marie Lain for her exceptionally impeccable timing.

${ }^{1}$ Arthur J. Goldberg, The Court Sits-In the Center of the Storm, N.Y. TimES, Nov. 8, $1964, \S 6$ (Magazine), at 30 . Justice Goldberg served on the Warren Court from October 1962 to July 1965. Linda Greenhouse, Arthur J. Goldberg, in 2 ENCYCloPEDIA OF THE AMERICAN CONSTITUTION 848, 848 (Leonard W. Levy et al. eds., 1986).

2 I credit Michael Klarman for coining the term "countermajoritarian hero." See, e.g., Michael J. Klarman, Brown, Originalism, and Constitutionalism Theory: A Response to Professor McConnell, 81 VA. L. REV. 1881, 1933-34 (1995) [hereinafter Klarman, A Response] (referring to the "myth of the Court as 'countermajoritarian hero"); Michael J. Klarman, Majoritarian Judicial Review: The Entrenchment Problem, 85 GEO. L.J. 491, 493 (1997) [hereinafter Klarman, The Entrenchment Problem] (arguing that "judges do not act as 'countermajoritarian heroes' or 'villains'”); Michael J. Klarman, Rethinking the Civil Rights and Civil Liberties Revolutions, 82 VA. L. REv. 1, 6 (1996) [hereinafter Klarman, Rethinking] (noting the "overblown nature of the [Supreme Court's] countermajoritarian hero image"); Michael J. Klarman, What's So Creat About Constitutionalism?, 93 NW. U. L. REv. 145, 192 (1998) [hereinafter Klarman, What's So Great] (arguing that "[o]nly one who thinks about judicial review ahistorically and acontextually could subscribe to the romantic vision of the Court as countermajoritarian hero").

${ }^{3}$ See United States v. Carolene Prods. Co., 304 U.S. 144, 152 n.4 (1938) ("Nor need we enquire ... whether prejudice against discrete and insular minorities may be a special condition, which tends seriously to curtail the operation of those political processes ordinarily to be relied upon to protect minorities, and which may call for a correspondingly more searching judicial inquiry."). 
as well, touting courts as "havens of refuge for those who might otherwise suffer because they are helpless, weak, outnumbered, or because they are nonconforming victims of prejudice and public excitement." It is hardly surprising, then, that as today's top constitutional scholars debate the merits of judicial review, ${ }^{5}$ its defenders have returned to the notion that the Court's involvement is necessary to protect minority rights. ${ }^{6}$ For some, like myself, the Supreme Court's role as countermajoritarian hero is theoretically appealing, but a nagging question remains-how much does the Court actually play it?

If ever a Court played the heroic, countermajoritarian role we romantically ascribe to judicial review, it was the Warren Court. ${ }^{7}$ After all, it was the Warren Court that Alexander Bickel was referring to when he coined the term "countermajoritarian difficulty," ${ }^{8}$ and it was

${ }^{4}$ Chambers v. Florida, 309 U.S. 227, 241 (1940).

5 See, e.g., Mark Tushnet, Taking the Constitution Away from the Courts 632 (1999) (arguing that judicial declarations deserve no preferential consideration); JEREMY WAIDRON, LAW AND DISAGREEMENT 285-91 (1999) (asserting that judicial review violates precepts of liberalism); Larry D. Kramer, Foreword: We the Court, 115 HARV. L. REV. 4, 12 (2001) (arguing that people, not the judiciary, should be the final resort for the resolution of constitutional disputes); Keith E. Whittington, Extrajudicial Constitutional Interpretation: Three Objections and Responses, 80 N.C. L. REV. 773, 779 (2002) (noting that "[a]ctive judicial intervention in constitutional debates and strong deference by political actors to judicial interpretations are not necessary for achieving constitutional order or preserving constitutional principles").

${ }^{6}$ See, e.g., Erwin Chemerinsky, In Defense of Judicial Review: The Perils of Popular Constitutionalism, David C. Baum Memorial Lecture, University of Illinois College of Law (Feb. 17, 2003) (arguing that the Constitution requires judicial review to adequately protect the rights of minorities), available at http://www.law.uiuc.edu/ conferences/baum/sp03.asp; see also Paul Butler, By Any Means Necessary: Using Violence and Subversion to Change Unjust Law, 50 UCLA L. REV. 721, 725 (2003) (arguing that it is the judiciary's duty "to protect racial minorities from tyranny"); Mark D. Rosenbaum \& Daniel P. Tokaji, Healing the Blind Goddess: Race and Criminal Justice, 98 MICH. L. REV 1941,1964 (2000) (arguing that it is the judiciary's role to protect the fundamental rights of racial minorities).

7 The Warren Court began with Earl Warren's recess appointment as Chief Justice in October 1953 and ended with his retirement in June 1969. G. Edward White, Warren Court, in 4 ENCYCLOPEDIA OF THE AMERICAN CONSTITUTION, supra note 1, at 2023, 2023.

${ }^{8}$ Professor Bickel explained:

The root difficulty is that judicial review is a counter-majoritarian force in our system.... [W] hen the Supreme Court declares unconstitutional a legislative act or the action of an elected executive, it thwarts the will of representatives of the actual people of here and now; it exercises control, not in behalf of the prevailing majority, but against it.

AleXander M. Bickel, The Least Dangerous Branch: The Supreme Court at The BAR OF POLITICS 16-17 (1962). 
the Warren Court that gave us Brown v. Board of Education. ${ }^{9}$ Earl Warren himself once declared, "Everything that I ever did in my life that was worthwhile I caught hell for," ${ }^{10}$ and the same was generally true for his Court. Accused of protecting blacks, communists, criminals, atheists, pornographers, and other perceived threats to white, middleclass America, the Warren Court was quite possibly the most vilified Supreme Court in United States history.

Yet even among the Warren Court's more controversial decisions, few rulings are thought to epitomize the heroic, countermajoritarian ideal better than those involving criminal procedure. By conventional wisdom, the Warren Court's criminal procedure rulings were "plainly, even aggressively countermajoritarian" - the one doctrinal area where the Court knew it lacked public support but took a stand anyway. ${ }^{12}$ Indeed, even constitutional historians who generally deny the Supreme Court's capacity for countermajoritarian decision making cite the Warren Court's criminal procedure decisions as exceptions to the rule, ${ }^{13}$ and for good reason. Together, these cases produced what

9347 U.S. 483 (1954); see also Klarman, Rethinking, supra note 2, at 19 (crediting Brown for the Court's image as "heroic defender of minority rights"); Anthony Lewis, Earl Warten, in 4 ENCYCLOPEDIA OF THE AMERICAN CONSTITLTION, supra note 1, at 2019, 2020 (noting that Earl Warren "represented the hope of authority bringing justice to the downtrodden" and crediting Brown for giving him that status).

${ }^{10}$ JaCk Harrison POllack, EARL WARREN: THE JUdGe Who CHANGEd AMERICA, at vii (1979) (quoting Chief Justice Warren).

${ }^{11}$ William J. Stuntz, The Uneasy Relationship Between Criminal Procedure and Criminal Justice, 107 YALE L.J. 1, 54 (1997).

${ }^{12}$ See Thomas Byrne EdSall \& MARy D. Edsall, Chain REAction: THE ImpaCt OF RACE, RIGHTS, AND TAXES ON AMERICAN POLITICS 110 (1991) ("Perhaps the most controversial of all the major rights movements identified with liberalism over the past twenty-five years were the initiatives in behalf of criminal defendants and prisoners."); MORTON J. HORWITZ, THE WARREN COURT AND THE PURSUIT OF JUSTICE 95 (1998) ("Of all the rulings of the Warren Court, none was more unpopular than its criminal justice decisions."); LUCAS A. POWE, JR., THE WARREN COURT AND AMERICAN POlitics 394 (2000) ("The criminal procedure revolution was the one area where the Court knew there was no public support for its actions."); STEPHEN L. WASBY, CONTINUITY AND CHANGE: From THE WARREN COURT TO THE BuRger COURT 75 (1976) (“[T] he reform of criminal procedure ... was the policy area in which the Court's most controversial set of rulings was handed down."); see also Ronald J. Bacigal, The Federalism Pendulum, 98 W. VA. L. REV. 771, 782 (1996) ("The Warren Court would buck popular consensus by swinging the federalism pendulum in favor of extending federal constitutional protections to those suspected of criminal activity.").

${ }^{13}$ See, e.g., Michael J. Klarman, Bush v. Gore: Through the Lens of Constitutional History, 89 CAL. L. REV. 1721, 1750 (2001) (recognizing Miranda y. Arizona as one of few cases where the Supreme Court's ruling was opposed by a clear majority of the nation); Michael J. Klarman, The Racial Origins of Modern Criminal Procedure, 99 MiCH. L. REV. 48, 49 (2000) [hereinafter Klarman, Racial Origins] (contrasting the Supreme Court's early criminal procedure cases with "the sort of countermajoritarian judicial decision 
is widely known as the "criminal procedure revolution," so vast were the protections afforded to unpopular and politically powerless criminal defendants. ${ }^{14}$ Like any revolution, the one to protect criminal defendants did not go unnoticed. Its most aggressive decisions drew criticism from coast-to-coast, faired poorly in major public opinion polls, triggered contrary legislation, and even inspired a backlash "law and order" campaign that helped send Richard Nixon to the White House in $1968 .^{15}$ It is therefore entirely understandable why scholars have viewed the criminal procedure revolution as the quintessential example of the Supreme Court playing a heroic, countermajoritarian role.

For all the credit the revolution has received, however, no one yet has paused to consider whether the Warren Court's criminal procedure decisions were truly the bastion of countermajoritarian decision making they have been made out to be. ${ }^{16}$ In fact, scholarship considering these decisions in their relevant social and political context is, as one author has noted, "virtually nonexistent."17 With last fall marking the fiftieth anniversary of Earl Warren's appointment as Chief Justice, ${ }^{18}$ enough time has passed to place the criminal procedure revolution in proper historical perspective and rethink the Court's role there as countermajoritarian hero. In the discussion that follows, I

making one often associates with landmark criminal procedure decisions such as Mapp or Miranda").

${ }^{14}$ The phrase "criminal procedure revolution" is commonly used to refer to the Warren Court's rulings of the 1960s that extended new constitutional protections to criminal defendants in state court. See, e.g., Craig M. Bradley, The Failure of THE CRIMINAl PROCEDURE REVOlution, at xi (1993) ("The 'criminal procedure revolution' refers to a series of constitutional decisions by the United States Supreme Court during the 1960s that 'revolutionized' the criminal procedures of the states."); Joseph L. Hoffman, Substance and Procedure in Capital Cases: Why Federal Habeas Corpus Courts Should Review the Merits of Every Death Sentence, 78 TEX. L. REV. 1771, 1782 n.57 (2000) (noting that the "so-called "criminal procedure revolution" refers to the Warren Court's "enforce[ment of] often-unpopular new federal constitutional rules" in state court proceedings); see also infra text accompanying note 57 (describing the Supreme Court's change in approach to criminal procedure in the 1960s).

${ }^{15}$ See infra text accompanying notes 65-68 and 205-08 (discussing the public and political reaction to Mapp v. Ohio, 367 U.S. 643 (1991), and Miranda v. Arizona, 384 U.S. 436 (1966)).

${ }^{16}$ Michael Klarman has come the closest. While recognizing the need for more scholarship in this area, he has suggested that "the entire criminal procedure revolution was intertwined with changing popular attitudes" toward poverty and race. Klarman, Rethinking, supra note 2, at 64 .

${ }^{17}$ Id. at 62.

${ }^{18}$ Earl Warren joined the Supreme Court as its fourteenth Chief Justice in October 1953, retiring in June 1969. Lewis, supra note 9, at 2019. 
aim to do that by examining five of the revolution's most celebrated decisions: Mapp v. Ohio, ${ }^{19}$ Gideon v. Wainwright, ${ }^{20}$ Miranda v. Arizona, ${ }^{21}$ Katz $v$. United States, ${ }^{22}$ and Terry $v$. Ohio. ${ }^{23}$ In none of these cases, I argue, did the Supreme Court act in a manner truly deserving of its countermajoritarian image. To be clear, I do not deny that these decisions were historically significant, salient events; nor do I deny that they were doctrinally revolutionary (though two fall short of even that mark). ${ }^{24}$ My point is simply that upon close inspection, the landmark cases of the criminal procedure revolution say more about the $\mathrm{Su}$ preme Court's lack of inclination for countermajoritarian decision making than the contrary-and that, in turn, has profound implications for the heroic, countermajoritarian function we tend to ascribe to judicial review.

Before proceeding, the scope of this Article warrants a few further points of clarification. First, I do not purport to provide a comprehensive analysis of the entire criminal procedure revolution. The Warren Court decided hundreds of criminal procedure cases, several dozen of which could be characterized as doctrinally significant, revolutionary decisions. ${ }^{25}$ I cannot possibly discuss all of these within the confines of a law review article, and thus my more modest aim: a discussion of the five decisions we most often think about when we think about the revolution, the decisions that made the revolution famous and helped create the Court's countermajoritarian image there. Whether these decisions fairly represent the revolution as a whole is a topic I leave for another day.

Second, even if (as I believe) the Warren Court's criminal procedure decisions were less countermajoritarian than we tend to think, I do not deny that, at times, they at least showcased the Court playing

\footnotetext{
19367 U.S. 643 (1961).

372 U.S. 335 (1963).

384 U.S. 436 (1966).

389 U.S. 347 (1967).

392 U.S. 1 (1968).
}

${ }^{24}$ See infra text accompanying notes 175-85 (discussing the doctrinal inevitability of Gideon); infra text accompanying notes 355-71 (discussing the same regarding Katz).

${ }^{25}$ See Francis A. Allen, The Judicial Quest For Penal Justice: The Warren Court and the Criminal Cases, 1975 U. ILL. L.F. 518, 519 ("In the sixteen years of Chief Justice Warren's tenure, the Supreme Court decided upwards of 600 criminal cases."). One need only open a criminal procedure textbook to catalogue the dozens of Warren Court cases that significantly shaped our modern jurisprudence. See generally RONALD JAY

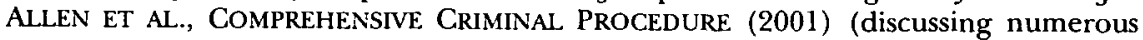
Warren Court decisions). 
countermajoritarian hero at the local level. ${ }^{26}$ Of course, whenever a locality is out of step with an emerging or established national consensus and the Supreme Court validates that consensus, its decision will be countermajoritarian in a way-but that kind of countermajoritarian decision making can occur even without judicial review. The 1964 Civil Rights Act, ${ }^{27}$ which was immensely unpopular in the South, amply demonstrates that Congress can play local countermajoritarian hero as well as the Court, at least when the nation's collective will is behind it. Thus, to the extent we need the Supreme Court's heroism, we need it to protect against an oppressive national majority, not a local one, and it is therefore the national sociopolitical context that is my focus.

Next, my claim that the Supreme Court lacks the inclination to make countermajoritarian decisions is not a claim that it watches election returns (or any other measure of public opinion) and then deliberately renders decisions that will enjoy popular support. Concededly, the Court sometimes bows to public or political pressure, as it did in 1937's "switch in time that saved the Nine,"28 and the Warren Court was not immune to this phenomenon. ${ }^{29}$ But by and large, the Justices

${ }^{26}$ See, e.g., Gideon v. Wainwright, 372 U.S. 335 (1963) (requiring the provision of counsel in all felony prosecutions for indigent defendants); see also infra Part I.C (discussing the Gideon case).

${ }^{27}$ Pub. L. No. 88-352, 78 Stat. 241 (codified as amended in scattered sections of 42 U.S.C.).

${ }_{28}^{28}$ The OXFord DictionaRY OF AMERICAN LEgal QuOTATIONS 393 (Fred R. Shapiro ed., 1993). The "switch" referred to Justice Owen J. Roberts" alleged change of position in West Coast Hotel Co. v. Parrish, 300 U.S. 379 (1937), upholding a key New Deal legislative program that coincided with the failure of President Franklin D. Roosevelt's “court-packing" plan. See Michael Arens, A Thrice-Told Tale, or Felix the Cat, 107 HARV. L. REV. 620, 625-34 (1994) (describing the historical circumstances surrounding the "court-packing plan" and contemporary allegations that Roberts had switched his vote in West Coat Hotel to prevent President Roosevelt and Congress from restructuring the Court). But see Felix Frankfurter, Mr. Justice Roberts, 104 U. PA. L. REv. 311, 313-15 (1955) (asserting that Justice Roberts voted to uphold the New Deal legislation in West Coast Hotel prior to Roosevelt's proposal).

${ }^{29}$ The Warren Court's change of heart on national security issues following its heavily criticized "Red Monday" decisions of 1957 provides a prime example. See HORWITZ, supra note 12, at 62-65 (describing the national security cases following Red Monday as "The Court in Retreat" and attributing that retreat to hostile reaction to the Court's earlier rulings); PAul L. MURPHY, THE CONSTITUTION IN CRISIS Times 334-36 (1972) (arguing that the change in the Warren Court's stance on domestic security issues was an "obvious and direct effect" of congressional pressure); POWE, supra note 12 , at 135 (noting that the Warren Court " $\mathrm{r}[\mathrm{an}]$ away from the domestic-security decisions of its 1956 Term as fast as it could"); Alan F. Westin, Also on the Bench: "Dominant Opinion", in THE SUPREME COURT UNDER EARL WARREN 63, 68-69 (Leonard W. Levy ed., 1972) (noting that in the face of criticism, the Warren Court "reacted by 
of the Warren Court saw their ability to make unpopular decisions when necessary as the judiciary's primary contribution to the political system $;{ }^{30}$ reading the election returns was the last thing they thought they were supposed to do, and the one thing they were rarely accused of doing. ${ }^{31} \quad$ This is not to suggest that the Warren Court tried to be countermajoritarian any more than it tried not to be. For the most part, I believe the Court made decisions based on what it thought the Constitution said, or at least meant to say, or at the very least should have said. In short, my claim that the Supreme Court lacks the inclination to make countermajoritarian decisions has less to do with any conscious considerations in the deliberative process and more to do with its natural tendency toward adopting majoritarian positions.

Finally, my claim that the Supreme Court is naturally inclined toward majoritarian positions has nothing to do with the political process in which the Justices are selected. Admittedly, the fact that the executive and legislative branches determine the Court's membership helps to ensure that the Justices' views somewhat resemble those of the electoral majority. Presidents nominate, and Senates confirm, individuals who generally think like them and their constituencies. ${ }^{32}$ But this "mirroring process" ${ }^{\text {"33 }}$ is short-term; Supreme Court Justices have a political life expectancy much longer than those who put them on the bench and thus their views could still differ from the prevailing ideology of any given moment. Moreover, the mirroring process is itself imperfect, and no appointment better illustrates the point than that of Chief Justice Warren- "'the biggest damn fool mistake"”

distinguishing or diluting virtually all of the bold and assertive rhetoric of the 1957 rulings").

See supra text accompanying note 1 (quoting Justice Goldberg's view of the Court's function); see also Fred Rodell, Crux of the Court Hullabaloo, in THE SuPREME COURT UNDER EARL WARREN, supra note 29, at 191, 195 (describing the judicial philosophy of Justices Black and Douglas as rhetorically asking "[w] hy have a written Bill of Rights-if not to protect against majority rule[?]").

${ }^{31}$ See The 'Warren Court' Era, N.Y. TIMES, June 22, 1968, at 1 ("The Warren Court was rarely accused of reading the election returns."). But see Fred P. Graham, New Tide in High Court, N.Y. TIMES, June 20, 1968, at 32 ("[T] he stop and frisk decision ... generate[s] feelings that the Justices are showing their ages or watching the election returns.").

${ }^{32}$ See Barry Friedman, Dialogue and Judicial Review, $91 \mathrm{MrCH}$. L. REV. 577, 613-14 (1993) ("As vacancies occur, presidents fill them with judges whose views are at least somewhat similar to their own and, more important, to the views of the people who elected them."). For an excellent discussion of the political aspects of the federal appointments process, see MICHAEL J. GERHARDT, THE FEDERAL APPOINTMENTS PROCESS: A CONSTITUTIONAL AND HISTORICAL ANALYSIS (2000).

${ }^{33}$ Friedman, supra note 32, at 614. 
President Eisenhower claimed he ever made. ${ }^{34}$ Thus, although the process by which Justices are selected may contribute to their majoritarian leanings, it need not do so, and in any event, it is not the impediment to countermajoritarian decision making that is my focus.

My focus is on the Supreme Court's tendency to adopt majoritarian positions just because of the sociopolitical context in which it operates. The Court is a part of contemporary society, and so we can (and should) expect its decision making to be naturally influenced by contemporary societal norms. Indeed, it would be naive to think that the Court could remain unaffected by the dominant normative assumptions of its time, even if it wanted. ${ }^{35}$ We should therefore not be surprised to see Supreme Court Justices take positions coinciding with those of the general public; the same historical events that shape our opinions also shape theirs, and the same social and political currents that move the rest of the country will undoubtedly move them as well. Judges are, after all, people too. And when we forget that fact-when we ignore the indelible historical context in which the Supreme Court operates-we get a distorted image of the Court and overestimate what it can realistically accomplish with judicial review.

In the discussion that follows, I argue that even the landmarks of the criminal procedure revolution illustrate the Supreme Court's tendency to decide cases consistent with the prevailing policy positions and ideology of its time. In Part I, I consider two of the revolution's early landmark decisions, Mapp v. Ohio ${ }^{36}$ and Gideon v. Wainuright. ${ }^{37}$ Given the historical context in which each case was decided, I conclude that Mapp reflected an emerging national consensus about the exclusionary rule and federal intervention in state criminal justice

34 MELVIN UROFSKY, THE WARREN COURT: JUSTICES, RULINGS AND LEGACY 90-91 (2001) (quoting President Eisenhower); see also POLLACK, supra note 10, at 12 (noting that President Eisenhower saw Earl Warren as "high level mediocrity," a middle-of-theroad politician too good at pleasing the masses to upset the status quo with novel constitutional interpretations).

${ }^{35}$ See Michael J. Klarman, Rethinking the History of American Freedom, 42 WM. \& MARY L. REV. 265, 278 (2000) (reviewing ERIC FONER, THE STORY OF AMERICAN FreEdom (1998)) ("Judges are part of contemporary culture and thus are exceedingly unlikely to interpret the Constitution in ways that depart dramatically from contemporary public opinion."); Steven L. Winter, An Upside/Down View of the Countermajoritarian Difficulty, 69 TEX. L. REV 1881, 1925 (1991) ("[J]udges cannot even think without implicating the dominant normative assumptions that shape their society and reproduce their political and cultural context."); see also BENJAMIN N. CARDOZO, THE NATURE OF THE JUDiCIAL Process 168 (1921) ("The great tides and currents which engulf the rest of men, do not turn aside in their course, and pass the judges by.").

${ }_{36} 367$ U.S. $643(1961)$.
${ }^{37} 372$ U.S. 335 (1963). 
affairs, while Gideon validated a well-established national consensus as to the necessity of legal assistance for indigent felony defendants. In Part II, I examine the strongest example of the Court's countermajoritarian inclinations in the criminal justice area, Miranda $v$. Arizona. ${ }^{38}$ While conceding that Miranda was controversial, $\mathrm{I}$ argue that it too was a product of its time and well within the parameters of publicly acceptable responses to the problem of coercive interrogation. In Part III, I address two of the revolution's later landmark decisions, Katz v. United States ${ }^{39}$ and Terry v. Ohio. ${ }^{40} \mathrm{Katz}$, I argue, was a welcomed concession to law enforcement interests on the issue of wiretapping at a time when the country as a whole was becoming more conservative on criminal justice issues. Terry, I contend, was a complete capitulation to law enforcement interests at a time when "law and order" dominated the national mood. In Part IV, I conclude the analysis, underscoring the need to recognize the Court's inherent limitations and adjust our expectations of judicial review.

\section{IN THE BEGINNING}

The most sensible starting point for any historical discussion of the criminal procedure revolution is at the beginning, when a change in the Court's stance on criminal procedure first became apparent in 1961. Yet change is a relative concept, and revolutionary change no less so. Thus, to understand what the revolution was and did, it is first instructive to understand what life for criminal defendants was like before it.

\section{A. Before the Revolution}

Before the revolution, as now, only around $1 \%$ of all criminal cases were prosecuted at the federal level. ${ }^{41}$ As a practical matter, then, the only constitutional protections that mattered for the vast majority of criminal defendants were those available in state, as opposed to federal, courts. Prior to the revolution, the distinction was

\footnotetext{
384 U.S. 436 (1966).

389 U.S. 347 (1967).

40 392 U.S. 1 (1968).
}

${ }^{41}$ See Fred P. GRaham, The Self-Inflicted WOUNd 29 (1970) ("[U]pwards of 99.6\% of the criminal cases in the [United States] are handled by the states."); WAYNE LAFAVE eT AL., CRIMINAL PROCEDURE 4 (3d ed. 2000) ("[T] he federal system is responsible each year for less than $2 \%$ of the total number of criminal prosecutions brought in the United States ...."). 
an important one. Criminal defendants in federal courts received the full panoply of protections enumerated in the Fourth, Fifth, Sixth, and Eighth Amendments. Criminal defendants in state courts, by contrast, were protected only by the Fourteenth Amendment's Due Process Clause, which the Supreme Court early on refused to interpret as incorporating the Bill of Rights guarantees. ${ }^{42}$ Thus, for some ninety-nine percent of all criminal defendants, those guarantees-at least as a matter of federal constitutional law-were no guarantee at all.

This is not to say that the Fourteenth Amendment's Due Process Clause failed to provide state criminal defendants with any protection whatsoever. To the contrary, it required states to meet a standard of "fundamental fairness" in their criminal prosecutions, ${ }^{43}$ which, at least in certain instances, necessitated providing defendants with protections akin to those enumerated in the Bill of Rights. Thus, while fundamental fairness did not require application of the full Sixth Amendment right to counsel, ${ }^{44}$ it did require the appointment of an attorney when state defendants were charged with a capital crime ${ }^{45}$ or when other "special circumstances" made one particularly necessary. ${ }^{46}$ Similarly, although fundamental fairness did not require application of the Fifth Amendment's prohibition against compelled selfincrimination, ${ }^{47}$ it did bar the admission of plainly coerced confessions

${ }^{42}$ See, e.g., Twining v. New Jersey, 211 U.S. 78, 113-14 (1908) (holding that the Fifth Amendment privilege against self-incrimination was not an essential component of the Fourteenth Amendment's Due Process Clause); Maxwell v. Dow, 176 U.S. 581, 604 (1900) (rejecting claim that an eight-person criminal jury violated the Sixth Amendment and suggesting that the Fourteenth Amendment's Due Process Clause may not require state jury trials at all); see also Adamson v. California, 332 U.S. 46, 50-51 (1947) (rejecting argument that the Fourteenth Amendment incorporated the Bill of Rights and applied it to the states).

${ }^{43}$ See LAFAVE ET AL., supra note 41 , at 55 (discussing the fundamental fairness doctrine).

${ }^{44}$ See Betts v. Brady, 316 U.S. 455, $471-72$ (1942) (upholding state court decision denying counsel to indigent defendants).

${ }_{45}$ See Powell v. Alabama, 287 U.S. 45, 71 (1932) (requiring the provision of defense counsel for capital crimes).

${ }^{46}$ See Betts, 316 U.S. at $472-73$ (holding that in special circumstances states may be required to provide counsel); see also LAFAVE ET AL., supra note 41, at 555-56 (discussing Betts' "special circumstances" rule).

${ }^{47}$ See Adamson, 332 U.S. at 50-51 (rejecting argument that the Fourteenth Amendment incorporated the Fifth Amendment's protection against compelled self-incrimination). 
at state trials. ${ }^{48}$ And even though fundamental fairness did require application of the Fourth Amendment's prohibition against unreasonable searches and seizures in state courts, it did not require evidence obtained in violation of that prohibition to be excluded at trial, as was the rule in federal courts. ${ }^{49}$ In state courts, evidence was constitutionally inadmissible only when it was obtained in a manner so offensive as to "shock[] the conscience" of the Court (if not also churn its stomach). ${ }^{50}$ In short, the fundamental fairness doctrine provided state criminal defendants with some protections, but it fell far short of those afforded under the Bill of Rights. Because the doctrine prevented only the most unfair state practices, it was more like a litmus test of egregiousness, eradicating abuses based on the same "I know it when I see it" approach Justice Stewart would later use to describe pornography. ${ }^{51}$

With the Supreme Court otherwise unwilling to interfere in the administration of state criminal justice, criminal defendants before the revolution were largely dependent on the states for their treatment before, during, and after trial. As a practical matter, that meant the quality of criminal "justice" rendered before the revolution varied from state to state and, all too often, with the color of a defendant's skin. Particularly in the Deep South, where racial prejudice fueled already hostile sentiment toward those accused of criminal wrongdoing, defendants were routinely treated like pieces of meat to be processed and then forwarded for proper packaging. ${ }^{52}$ Police plucked individuals off the streets for little or no reason, searched them without

${ }^{48}$ See Brown v. Mississippi, 297 U.S. 278, 286 (1936) (excluding evidence obtained by brutality and violence). The facts of Brown are discussed infra in notes 212-13 and accompanying text.

${ }^{49}$ Compare Weeks v. United States, 232 U.S. 383, 393 (1914) (requiring an exclusionary rule in federal courts), with Wolf v. Colorado, 338 U.S. 25, 33 (1949) (refusing to extend the exclusionary rule to the states).

${ }^{50}$ See Rochin v. California, 342 U.S. 165, 172 (1952) (holding that the use of a stomach pump to retrieve evidence in the defendant's vomit "shocks the conscience" and is therefore constitutionally inadmissible).

${ }^{51}$ See Jacobellis v. Ohio, 378 U.S. 184, 197 (1964) (Stewart, J., concurring) ("I shall not today attempt further to define the kinds of material I understand to be embraced within th [e] shorthand description [of hard-core pornography]; and perhaps I could never succeed in intelligibly doing so. But I know it when I see it . ...").

${ }^{52}$ See Yale Kamisar, Equal Justice in the Gatehouses and Mansions of American Criminal Procedure, in CRIMINAL JUSTICE IN OUR TIME 1, 14-19 (A. E. Dick Howard ed., 1965) (comparing treatment of defendants to cattle); Richard Neely, The Warren Court and the Welcome Stranger Rule, in THE WARREN COURT: A RETROSPECTIVE 184, 185 (Bernard Schwartz ed., 1996) (noting that "[i]n the 1960s, the average criminal [suspect] was treated like a piece of meat on its way to dressing and processing"). 
a warrant, questioned them using strong-arm tactics, and then (if sufficiently satisfied with the evidence of guilt) sent them on to the formal adjudication process for trial or, more likely, a guilty plea. ${ }^{53}$ In sum, many state criminal justice systems before the revolution presented “'dismal pictures of official lawlessness," "54 and criminal defendants, who were disproportionately poor, uneducated, and black, ${ }^{55}$ lacked the wherewithal to do anything about it. They needed a hero.

Beginning in 1961, the Warren Court gave them one, at least for a while. Tired of the steady stream of abuses that continued to filter up from the states, the Supreme Court of the 1960s made policing the police, as well as state courts, a distinctly federal concern. In all fairness, the Warren Court showed some concern for criminal defendants in the late 1950s as well, but its early attempts at cleaning up criminal procedure were "sporadic and doctrinally modest" at best ${ }^{56}-$ nothing like the activism that would later mark the Court's decisions in this area. It was not until 1961 that the Supreme Court started making wholesale revisions to state criminal justice practices, demonstrating what would become a sustained interest in protecting criminal defendants on more than an ad hoc basis. By the time it was finished, the Court would incorporate into the Fourteenth Amendment's Due Process Clause nearly all of the relevant Bill of Rights guarantees, adding bold new content to more than a few along the way. ${ }^{57}$ Clearly, the Supreme Court's shift in stance on criminal procedure was itself

${ }^{53}$ See Kamisar, supra note 52, at 19 ("The legal courts ... [were] reduced to the position of merely ratifying the plea of guilt which the police ha[d] obtained." (quoting Ernest J. Hopkins, The Lawless Arm of the Law, ATLANTIC MONTHLY, Sept. 1931, at 279, 280-81)); Neely, supra note 52, at 185-86 (discussing the unfair treatment of suspected criminals by both the police and the courts).

${ }^{54}$ Russell Porter, Justice Brennan Finds Court Flaw, N.Y. TimES, Feb. 16, 1961, at 21 (quoting a speech by Justice William J. Brennan, Jr.).

${ }^{55}$ See White, supra note 7, at 2029 (noting that "a high percentage of criminals in the 1960 s were poor and black"); see also GRAHAM, supra note 41, at 86-101 (reporting sociological data that blacks committed proportionately more crimes than whites because of their disproportionate representation in low-status groups that tended to commit more crime); Richard J. Medalie et al., Custodial Police Interrogation in Our Nation's Capital: The Attempt to Implement Miranda, 66 MICH. L. REv. 1347, 1357 (1968) (describing the typical criminal defendant as "a young, single, Negro, male recidivist of low socioeconomic status characterized by low income, low educational attainment, high unemployment, poor job status, borderline overcrowded living accommodations, and a dearth of voluntary affiliations").

${ }^{56}$ Dan M. Kahan \& Tracey L. Meares, Foreword: The Coming Crisis of Criminal Procedure, 86 GEO. L.J. 1153, 1155 (1998).

${ }_{57}$ See LAFAVE ET AL., supra note 41, at 70-71 (discussing the selective incorporation doctrine of 1960 s criminal procedure cases). 
revolutionary-and that shift began with the Court's 1961 decision in Mapp v. Ohio. ${ }^{58}$

\section{B. Mapp v. Ohio: The Launch of a Revolution}

Widely recognized for launching the criminal procedure revolution, ${ }^{59}$ Mapp $v$. Ohio required state courts to exclude evidence obtained in violation of the Fourth Amendment, just as federal courts had done since $1914 .^{60}$ According to Mapp, the exclusionary rule was more than just an evidentiary concept to be adhered to or discarded at each state's will; it was an integral part of the Fourth Amendment and thus fully binding on the states under the Fourteenth Amendment's Due Process Clause. ${ }^{61}$ As contemporary observers quickly recognized, Mapp was no ordinary case. Commentators reacting to the decision called it "the most significant limitation ever imposed on state criminal procedure by the Supreme Court in a single decision," 62 and they were right. Gone in one fell swoop was the Court's willingness to intervene in only the most egregious state criminal procedure cases; that approach had marked the Court's 1949 decision in Wolf $v$. Colorado, ${ }^{63}$ which Mapp overruled. Equally remarkable was the setting in which the Supreme Court chose to inaugurate its dramatically different approach to state criminal procedure. In Mapp, the Court not only eschewed an ad hoc approach in favor of a bright-line rule, but

58367 U.S. 643 (1961).

59 See, e.g., Ed Cray, ChIEF Justice: A BIOGRAPHY OF EARL WARREN 375 (1997) (marking the beginning of the criminal procedure revolution in 1961, when the Supreme Court decided Mapp); PowE, supra note 12, at 195 (same); Allen, supra note 25, at 519 (same); Gerald G. Ashdown, Drugs, Ideology, and the Deconstitutionalization of Criminal Procedure, 95 W. VA. L. REV. 1, 2 (1992) (same); Yale Kamisar, The Warren Court and Criminal Justice, in THE WARREN COURT: A RETROSPECTIVE, supra note 52, at 116, 116 (same); Lewis R. Katz, Mapp After Forty Years: Its Impact on Race in America, 52 CASE W. RES. L. REV. 471,478 (2001) (same).

${ }^{60}$ Mapp, 367 U.S. at 654-55; see also Weeks v. United States, 232 U.S. 383, 393 (1914) (imposing the exclusionary rule on federal courts).

61 367 U.S. at 657.

${ }^{62}$ High Court Bars Evidence States Seize Illegally, N.Y. TIMES, June 20, 1961, at 1. The Warren Court Justices also recognized Mapp's enormous import. See CRAY, supra note 59, at 375 ("Mapp was 'so terribly important,' Warren told his son, so important, Earl Junior decided that 'it's hard to say it's a case. It's like a huge cloud from which a lot of things are raining."'); BERNARD SCHWARTZ, SUPER CHIEF: EARL WARREN AND HIS SUPREME COURT-A JUDICIAL BIOGRAPHY 391 (1983) (noting Justice Abe Fortas' description of Mapp as "the most radical decision in recent times").

338 U.S. 25 (1949). 
the bright-line rule it chose invalidated a long-established practice in roughly half the states. ${ }^{64}$

Not surprisingly, Mapp was less than well received in certain quarters. Police across the country cried loudly in protest, blaming the decision for a burglary wave in Minneapolis (which they later attributed to lack of snow) ${ }^{65}$ and a decrease in narcotics convictions in New York. ${ }^{66}$ In their view, Mapp posed a serious obstacle to law enforcement, one that the public might not be able to tolerate. ${ }^{67}$ Those more solicitous of states' rights than the Court found Mapp disturbing as well. The President of the American Bar Association, for example, publicly criticized the Court for turning state criminal law into "a mere appendage of [f]ederal constitutional law" while giving "inordinate weight" to defendants' rights. ${ }^{68}$ With comments like that, Mapp's holding appeared to be as controversial as it was consequential. Indeed, scholars have long regarded Mapp as one of the two most unpopular criminal procedure decisions in Supreme Court history, ${ }^{69}$ making it a seemingly perfect example of the Court's countermajoritarian role in the criminal procedure revolution.

In part, understanding the Court's ruling in Mapp requires an understanding of the facts of the case. Dollree Mapp was no saint, ${ }^{70}$ but

${ }^{64}$ See High Court Bars Evidence States Seized Illegally, supra note 62, at 1 (noting that twenty-four states admitted illegally seized evidence before Mapp); see also Elkins v. United States, 364 U.S. 206 app. at 224-25 tbl.1 (1960) (listing each state's position on the exclusionary rule as of 1960).

${ }^{65}$ See Yale Kamisar, On the Tactics of Police-Prosecution Oriented Critics of the Courts, 49 CORNELL L.Q. 436, 439 (1964) (discussing police comments to local papers).

${ }^{66}$ Leonard E. Ryan, Narcotics Case Convictions Drop Since Ban on Illegal Searches, N.Y. Times, Sept. 19, 1962, at 35.

${ }^{67}$ See Kamisar, supra note 65, at 440 (noting comments of local police superintendent doubting "that the public 'can live' with the exclusionary rule"); Limit on Searches Scored by Police, N.Y. TIMES, Sept. 23, 1962, at 74 (reporting police commissioners' views that the exclusionary rule was an obstacle to effective law enforcement).

${ }_{68}$ Anthony Lewis, Bar Chief Assails High Court Views, N.Y. TIMEs, Aug. 6, 1962, at 7.

${ }^{69}$ The other is Miranda v. Arizona, 384 U.S. 436 (1966). See, e.g., Bacigal, supra note 12, at 782 (noting that "Mapp v. Ohio, which extended the Fourth Amendment exclusionary rule to the states, and Miranda $v$. Arizona, which required the now famous warnings, must rank among the most unpopular decisions in Supreme Court history" (footnotes omitted)); Klarman, Racial Origins, supra note 2, at 49 (contrasting the Supreme Court's early criminal procedure cases with "the sort of countermajoritarian judicial decision making one often associates with landmark criminal procedure decisions such as Mapp or Miranda"); Stuntz, supra note 11, at 53 (arguing that decisions like Mapp and Miranda are "nothing if not countermajoritarian").

${ }^{70}$ See CRAY, supra note 59, at 375 (noting that Mapp later moved to Queens, New York, where she was ultimately convicted of operating a heroin factory out of her home and sentenced to a prison term of twenty years to life). 
she presented about as attractive a case for overruling Wolf $v$. Colorado ${ }^{71}$ as one could ever find. Mapp lived in a boarding house in Cleveland and was under investigation for harboring an alleged bombing suspect. $^{72}$ When police arrived at her home and demanded entry, Mapp called her lawyer, who advised her not to admit them without a warrant. ${ }^{73}$ She did exactly that, but the police (who numbered at least seven) broke the glass on a back door and entered the home anyway. ${ }^{74}$ When Mapp at once demanded to see their warrant, one of the officers waived a paper in front of her, which she grabbed and stuffed inside her bra. ${ }^{75}$ The police went after it. Mapp resisted and a struggle ensued over the warrant's "official rescue" from her bosom. ${ }^{76}$ The officers eventually retrieved their paper, at which time they handcuffed Mapp for acting belligerent and searched her house. ${ }^{77}$ In the basement they found a trunk containing the pornographic materials for which Mapp was ultimately prosecuted: four pamphlets, a couple of smutty pictures, and "a little pencil doodle." Although Mapp insisted that the trunk and its contents belonged to a recent boarder, she was convicted for possession of obscene material and sentenced to one to seven years' imprisonment. ${ }^{79}$

As it turned out, the police never had a warrant to search Mapp's home in the first place, ${ }^{80}$ though at the time that was irrelevant.

${ }^{71} 338$ U.S. 25 (1949).

${ }^{72}$ Mapp, 367 U.S. at 644 . Interestingly, that suspect was believed to have bombed the home of future boxing promoter Don King, who at the time was an alleged numbers racketeer. See Fred W. FRIENDLy \& MARTHA J. H. EllLIOTT, THE CONSTITUTION: THAT DEliCATE BALANCE 129 (1984) (noting that "Don King . . . who would later become the prominent promoter of championship boxing bouts," reported the bombing that led to the Mapp case); see also Katz, supra note 59, at 471 ("[P]olice officers, looking for a man suspected of bombing Don King's home, surrounded Dollree Mapp's house ....”). I credit Michael Allen Wolf for locating this bit of trivia.

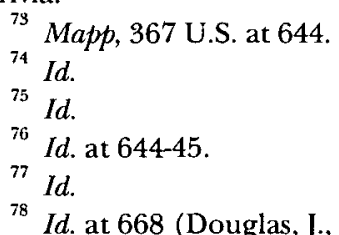
revealed the pornographic materials).

${ }_{80}^{79}$ Id. at 668-69 (Douglas, J., concurring).

${ }^{80}$ See id. at 645 ("At the trial no search warrant was produced by the prosecution, nor was the failure to produce one explained or accounted for. At best, 'There is, in the record, considerable doubt as to whether there ever was any warrant for the search of defendant's home." (quoting State v. Mapp, 166 N.E.2d 387, 389 (Ohio 1960))). A police offer involved in the search later admitted that they had never secured a warrant. FRIENdLY \& ElLIOTT, supra note 72, at 130-31. 
Under the Supreme Court's decision in Wolf $v$. Colorado, the exclusionary rule was optional, so states like Ohio could convict a defendant on illegally obtained evidence if they pleased. ${ }^{81}$ Still, the facts of Mapp made crystal clear what Wolf had become in practice-a green light for police to break the law. The old adage " $[t]$ he criminal is to go free because the constable has blundered" ${ }^{\prime 82}$ had lost its intuitive appeal under the facts of Mapp; police were violating the Fourth Amendment on purpose, not by accident, because they had no reason not to. At the very least, then, Mapp's egregious facts made it easier for the Supreme Court to forge a new doctrinal path. Indeed, Mapp even afforded the Court the relatively rare opportunity to reverse on a Fourth Amendment claim where the defendant's factual guilt was in doubt.

Even so, egregious facts would not have led to Mapp's revolutionary ruling unless the Justices were already poised to make it, as two points amply demonstrate. First, Mapp began inconspicuously enough as a First Amendment case and was briefed and argued as such before the Supreme Court. ${ }^{83}$ In fact, when Mapp's lawyer was asked during oral argument whether he also wanted the Court to reconsider its ruling in Wolf, he declined the invitation. ${ }^{84}$ Only the closing lines of an American Civil Liberties Union amicus brief requested the Supreme Court in Mapp to rethink Wolf, and its request consisted of just three sentences completely devoid of argument. ${ }^{85}$ Adding to the irony, a

${ }^{81}$ See Wolf, 338 U.S. at 33 ("[I]n a prosecution in a State court for a State crime the Fourteenth Amendment does not forbid the admission of evidence obtained by an unreasonable search and seizure.").

${ }^{82}$ People v. Defore, 150 N.E. 585, 587 (N.Y. 1926).

${ }^{83}$ Brief for Appellants, Mapp v. Ohio, 367 U.S. 643 (1961) (No. 236), reprinted in 55 LANDMARK BRIEFS AND ARGUMENTS OF THE SUPREME COURT OF THE UNITED STATES 1081-1112 (Philip B. Kurland \& Gerhard Casper eds., 1975) [hereinafter LANDMARK BRIEFS]; Oral Argument, Mapp (No. 236), reprinted in 55 LANDMARK BRIEFS, supra, at 1157-1200.

${ }^{84}$ Oral Argument at 8-9, Mapp (No. 236), reprinted in 55 LANDMARK BRIEFS, supra note 83, at 1157, 1165-66; see also Mapp, 367 U.S. at 673, 673-74 nn.4-6 (Harlan, J., dissenting) (quoting at length Mapp's statement of the questions raised on appeal and noting counsel's failure to advocate overruling Wolf during oral arguments).

${ }^{85}$ Brief of Amicus Curiae American Civil Liberties Union at 20, Mapp (No. 236), reprinted in 55 LANDMARK BRIEFS, supra note 83, at 1131, 1154; see also Mapp, 367 U.S. at 673 n.5 (Harlan, J., dissenting) (reproducing the ACLU's request for reconsideration of Wolf). Even at oral argument, ACLU's counsel emphasized that its "principal reason" for appearing before the Court was to argue that Ohio's obscenity statute was unconstitutionally vague. See Oral Argument at 13, Mapp (No. 236), reprinted in 55 LANDMARK BRIEFS, supra note 83, at 1170 ("Our principal reason for appearing on behalf of the American Civil Liberties Union and its Ohio affiliate is to urge the unconstitutionality of the Ohio obscenity law ...."). 
majority of the Justices in conference had already agreed to reverse Mapp's conviction on First Amendment grounds, so there was no need to even address the more difficult Fourth Amendment issue. ${ }^{86}$ In short, Justice Harlan was undeniably correct when he argued in dissent that the Mapp majority had "reached out" to overrule Wolf. ${ }^{87}$ For those members of the Court already inclined to impose the exclusionary rule on the states, Mapp provided the perfect opportunity to do it, First Amendment case notwithstanding.

Second, and equally revealing, the Supreme Court had confronted the same sort of egregious police conduct seven years earlier in the 1954 case of Irvine v. Califormia ${ }^{88}$ but had little difficulty affirming Wolf under those facts. ${ }^{89}$ In Irvine, police sent a locksmith to the defendant's home while he was absent to make a key to his door. ${ }^{90}$ They then entered the defendant's home on three separate occasions to install and move a microphone hidden in his bedroom. ${ }^{91}$ For over a month, the police listened in on the private marital communications (and presumably, intimacies) of Irvine and his wife, not once attempting to secure a warrant for intrusions that would have landed anyone else in jail. ${ }^{92}$ The Justices were outraged. Noting that the police conduct in Irvine "would be almost incredible if it were not admitted," they went on to say that "[f] ew police measures have come to our attention that more flagrantly, deliberately, and persistently violated . . . the Fourth Amendment.. ${ }^{93}$ Still, the Court affirmed Irvine's conviction for illegal gambling, reasoning that it would rarely be proper to force the exclusion of evidence in a state prosecution when the burden of administering criminal justice rested almost entirely with the states. ${ }^{94}$ Although Irvine was a difficult five-four decision for the Court and produced only a plurality opinion, the central dispute in that case was whether the police conduct was shocking enough to

${ }^{86}$ The Supreme Court in Conference (1940-1985): The Private Discussions BEHIND NEARLY 300 SUPREME COURT DECISIONS 486 (Del Dickson ed., Oxford 2001) [hereinafter THE SUPREME COURT IN CONFERENCE] (reproducing the Conference notes on Mapp).

${ }^{87}$ Mapp, 367 U.S. at 674 (Harlan, J., dissenting).

887 U.S. 128 (1954).

${ }^{89}$ See id. at 134 (Jackson, J., plurality opinion) ("We think that the Wolf decision should not be overruled for the reasons so persuasively stated therein.").

${ }^{90}$ Id. at 130-31 (Jackson, J., plurality opinion).

${ }_{91}$ Id. at 131 (Jackson, J., plurality opinion).

${ }^{92} I d$. at 132 (Jackson, J., plurality opinion).

93 Id. (Jackson, J., plurality opinion).

${ }^{94}$ See id. at 134 (Jackson, J., plurality opinion) (declining to overrule Wolf because " $[t]$ he chief burden of administering criminal justice rests upon state courts"). 
require exclusion under the fundamental fairness doctrine, not whether the fundamental fairness doctrine required overruling Wolf. ${ }^{95}$ Wolf's continuing validity, at least as of 1954 , was never in serious doubt.

Thus, although appealing facts certainly made the case for overruling Wolf more compelling, they alone cannot explain the Court's willingness in 1961 to impose upon the states a federal notion of justice. So what had changed since 1954? One answer is the composition of the Court, as four new Justices joined the bench between the years Irvine and Mapp were decided. ${ }^{96}$ With the exception of Justice Brennan, however, these were all relatively conservative appointments; the Warren Court did not become decidedly liberal in composition until 1962-after Mapp was decided. ${ }^{97}$ Moreover, although Justice Brennan helped form the five-justice majority in Mapp, that majority would not have materialized had not two other Justices also changed their minds about the exclusionary rule. One of the two, Justice Black, had been a member of the original majority in Wolf, ${ }^{98}$ while the other, Chief Justice Warren, had joined the plurality in Irvine that explicitly endorsed Wolf's hands-off rule and rationale. ${ }^{99}$ Given these considerations and the fact that conservative Justice Clark authored

${ }^{95}$ Compare id. at 133-34 (Jackson, J., plurality opinion) (concluding that because police conduct did not entail physical violence to the defendant's person, admission of the evidence did not violate fundamental fairness), with id. at 144-49 (Frankfurter, J., dissenting) (arguing that police conduct was sufficiently outrageous to "shock the conscience" despite lack of physical violence and therefore admission of that evidence violated fundamental fairness).

${ }_{96}$ In October 1954, Justice Jackson died; Justice Harlan replaced him in March 1955. In September 1956, Justice Minton retired; Justice Brennan replaced him in March 1957. In January 1957, Justice Reed retired; Justice Whittaker replaced him that March. In October 1958, Justice Burton retired; Justice Stewart replaced him in May 1959. See ARNOLd S. RICE, THE WARREN COURT, 1953-1969, at 6-17 (1987) (discussing the evolution of the Warren Court and the tenure of the individual Justices).

${ }^{97}$ See id. at 20 (noting that the Warren Court's conservative voting block lost control in 1962, when liberal Justice Arthur Goldberg replaced conservative Justice Felix Frankfurter); Kermit K. Hall, The Warren Court: Yesterday, Today, and Tomorrow, 28 IND. L. REV. 309, 315 (1995) (noting conventional wisdom that the increase in liberal decisions in the early 1960 s resulted from Justice Goldberg's appointment at the beginning of the 1962 term); see also Rice, supra note 96, at xi-xii (discussing the liberal and/or conservative bent of individual Warren Court Justices).

${ }^{88}$ See Wolf, 338 U.S. at 39-40 (Black, J., concurring) ("But I agree with what appears to be a plain implication of the Court's opinion that the federal exclusionary rule is not a command of the Fourth Amendment but is a judicially created rule of evidence which Congress might negate.").

${ }_{99}$ See Irvine, 347 U.S. at 134 (Jackson, J., plurality opinion) ("We think that the Wolf decision should not be overruled, for the reasons so persuasively stated therein."). 
the Mapp opinion, something else had to be driving the result in Mapp besides the Court's increasingly liberal composition-but what? Concededly, the question can never be answered in any definitive sense, though evolving legal and extralegal contexts afford the most plausible explanation.

\section{Mapp's Legal Context}

As the Supreme Court in Mapp openly acknowledged, its decision to overrule Wolf was based in part on the exclusionary rule's growing support at the state level. ${ }^{100}$ According to the Court, almost two-thirds of the states had rejected the exclusionary rule in 1949, when Wolf was decided, while more than half of the states had adopted it by $1960 .^{101}$ Truth be told, the Court was only talking about an eight-state gain, for a grand total of twenty-six states in favor of the exclusionary rule when Mapp was decided-and those eight states included newcomers Alaska and Hawaii, which arguably had little choice in the matter. ${ }^{102}$ Still, the remaining six states to endorse the exclusionary rule after Wolf provide valuable insight as to just how accepted the rule had become by 1961. Four of the six states-Alabama, Maryland, North Carolina, and Rhode Island-adopted the exclusionary rule by statute, rather than judicial decision making, and in Rhode Island, the statute was passed after a judge rejected the exclusionary rule the year before. ${ }^{103}$ The

${ }^{100}$ See Mapp, 367 U.S. at 651 ("While in 1949, prior to the Wolf case, almost twothirds of the [s] tates were opposed to the use of the exclusionary rule, now ... more than half of those since passing upon it, by their own legislative or judicial opinion, have wholly or partly adopted or adhered to [it].").

${ }^{101}$ See id. (citing Elkins v. United States, 364 U.S. 206 app. at 22425 tbl.1 (1960))

${ }^{102}$ In 1949, when Wolf was decided, twenty-nine of the forty-nine states admitted illegally seized evidence, while in 1961, when Mapp was decided, twenty-four of fifty states still did. In addition to the five states that changed their position on the issue, Rhode Island, Hawaii, and Alaska adopted the exclusionary rule without having rejected it before Wolf, bringing the total number of states adopting the exclusionary rule between 1949 and 1961 to eight. See Elkins, 364 U.S. at app. 224-25 tbl.1 (listing each state's position on the exclusionary rule before and after the Wolf opinion). While federal territories, Hawaii and Alaska had been required to follow the exclusionary rule, so each would have had to overrule existing judicial precedent to reject the exclusionary rule upon achieving statehood. See Weeks v. United States, 232 U.S. 383,393 (1914) (requiring the exclusionary rule in federal courts).

${ }^{103}$ See ALA. CODE $\$ 210$ (1951) (enacting a limited exclusionary rule); MD. CoDE ANN., art. 35, $\$ 5$ (1951) (same); N.C. GEN. STAT. \$ 15-27 (1951) (adopting the exclusionary rule); R.I. GEN. LAWS $§ 9-19-25$ (1956) (same); State v. Hillman, 125 A.2d 94, 95-96 (R.I. 1956) (reexamining precedent rejecting the exclusionary rule based on a newly enacted statute to the contrary). For an excellent discussion of each state's position on the exclusionary rule after 1949, see E.H. Schopler, Annotation, Modern Status 
other two states, California and Delaware, adopted the exclusionary rule by overruling prior precedent, ${ }^{104}$ a move the Court considered to be "most illuminating." 105 Importantly, no state to consider the exclusionary rule rejected it during this time, whether deciding the question as a matter of first impression or after having experimented with the rule in practice. ${ }^{106}$

For the majority in Mapp, California's conversion to the exclusionary rule in 1955 was particularly persuasive. ${ }^{107}$ One might surmise that this was partly due to the fact that California was a recognized leader in progressive law enforcement practices, as well as Earl Warren's home state. ${ }^{108}$ The fact that California Supreme Court Chief Justice Roger Traynor, one of the nation's most respected and influential state jurists, authored the California opinion adopting the exclusionary rule probably played a role too-especially since he had written the 1942 opinion it overruled. ${ }^{109}$ None of this, however, was

of Rule Governing Admissibility of Evidence Obtained by Unlawful Search and Seizure, 50 A.L.R.2D 531, 556-68 (1957).

${ }^{104}$ See People v. Cahan, 82 P.2d 905 (Cal. 1955) (overruling People v. Gonzales, 124 P.2d 44 (Cal. 1942)); Rickards v. State, 77 A.2d 199 (Del. 1950) (overruling State v. Chuchola, 120 A. 212 (Del. 1922)).

${ }^{105}$ See Elkins, 364 U.S. at 220 ("The experience in California has been most illuminating. In 1955 the Supreme Court of that State resolutely turned its back on many years of precedent and adopted the exclusionary rule." (citation omitted)).

${ }^{106}$ Michigan is the only state that even comes close. In 1952, Michigan expanded its already established exception to the exclusionary rule to include in the class of nonexcludable items evidence related to drug offenses. See People v. Gonzales, 97 N.W.2d 16, 23-24 (Mich. 1959) (recognizing the validity of a 1952 state constitutional amendment expanding the class of nonexcludable evidence). In 1957, South Dakota recognized a limited return to the common law rule of admissibility, but it did so based on a statute that was passed long before Wolf was decided. See State v. Lane, 82 N.W.2d 286, 289-90 (S.D. 1957) (recognizing a limited return to common law rule of admissibility based on S.D. CODE $\$ 34.1102$ (1939)).

${ }^{107}$ See Mapp, 367 U.S. at 651 ("Significantly, among those now following the rule is California ....").

108 See SAMUel Walker, Popular Justice: A History of American Criminal JUSTICE 175 (1st ed. 1980) ("California made the greatest advances in both law enforcement and corrections through the 1940s and 1950s.... In other states reformers and progressive administrators looked to California for a model they might follow."). Given Earl Warren's law enforcement background, California's position on the exclusionary rule may well have struck him as particularly influential. See POLLACK, supra note 10, at 43-66 (discussing Warren's experience as a district attorney and state attorney general).

${ }^{00}$ See Cahan, 282 P.2d at 911 (overruling People v. Gonzales, 24 P.2d 44 (Cal. 1942)); see also POWE, supra note 12, at 199 (noting the well-respected and influential reputation of California Chief Justice Roger Traynor); Roger J. Traynor, Mapp v. Ohio at Large in the Fifty States, 1962 DUKE L.J. 319, 321 (referring to " $[\mathrm{t}]$ he education that leads a judge to overrule himself"). 
mentioned in Mapp. What did merit discussion was the reason California had changed its mind about the exclusionary rule: other methods of enforcing the Fourth Amendment had proven to be an abject failure in curbing the brazen, illegal practices of local police. ${ }^{110}$ To the majority in Mapp, the point was an important one. Indeed, cases like Irvine had led the Court to the same conclusion a full year before Mapp was decided."

Given the exclusionary rule's growing popularity among the states by 1961, it is worth noting even at this juncture of the analysis that $M a p p$ was not the aggressively countermajoritarian decision scholars thus far have thought it to be. By the time the Court decided Mapp, a solid half of the states had already adopted the exclusionary rule, with the trend among them unmistakably in favor of the Court's decision. ${ }^{112}$ Indeed, no state to consider the exclusionary rule after 1949 rejected it (despite Wolf's tacit encouragement to do so), while most of those adopting it used majoritarian politics to effectuate the change. ${ }^{119}$ With California's prestige behind the exclusionary rule as of 1955, the rule's momentum was, as the Court itself noted in 1960, "seemingly inexorable." It It would appear, then, that the Supreme Court's decision in Mapp coincided with an emerging national consensus on the exclusionary rule, albeit at its early stages. Even under the most begrudging analysis, however, the exclusionary rule imposed by Mapp had the support of half the states-hardly an example of the Court acting against a clear majority preference to the contrary. Had

110 See Mapp, 367 U.S. at 651 ("Significantly, among those now following the rule is California, which, according to its highest court, was 'compelled to reach that conclusion because other remedies have completely failed to secure compliance with the constitutional provisions ....'” (quoting People v. Cahan, 44 Cal. 2d 434, 445 (1955))).

111 See Elkins, 364 U.S. 206, 217 ("[O]ther remedies have completely failed to secure compliance with the constitutional provisions on the part of police officers with the attendant result that the courts under the old rule have been constantly required to participate in, and in effect condone, the lawless activities of law enforcement officers."). In Irvine, Justice Jackson and Chief Justice Warren noted the availability of a federal prosecution against the officers in that case, directing that the record and a copy of the opinion be forwarded to the Attorney General for possible action. Irvine, 347 U.S. at 137-38. Apparently, nothing was ever done, which profoundly affected at least Warren's perspective on the necessity of judicial involvement. See Bernard Schwartz, Earl Warren, in THE WARREN COURT: A RETROSPECTIVE, supra note 52, at 256, 268 (discussing Irvine and its effect on Chief Justice Warren's views regarding judicial activism).

112 See supra notes 101-06 and accompanying text (describing the trend among the states toward adoption of the exclusionary rule).

${ }^{113}$ Id.

114 Elkins, 364 U.S. at 219. 
the Supreme Court mandated the exclusionary rule in 1949, when it decided Wolf, one could have concluded differently. But the Court in Wolf refused to make that move, in part because state practices at the time did not support it. ${ }^{115}$

Still, it is one thing to recognize that the states were choosing the exclusionary rule on their own and quite another for the Supreme Court to force that choice upon them. Even the apparent futility of other means of enforcing the Fourth Amendment cannot fully explain the Court's impetus to overrule Wolf; after all, if the states were concluding for themselves that the exclusionary rule was necessary (an argument that had been made since 1914), ${ }^{116}$ why bother to intervene? If anything, the exclusionary rule's momentum among the states urged patience from the Court, not intervention-and in years past, the Justices would have agreed. ${ }^{117}$ By 1961, however, the Supreme Court was more interested in curbing police abuses than in waiting for the states to do it themselves. To understand why, one need only examine the extralegal context in which Mapp was decided.

\section{Mapp's Extralegal Context}

By 1961, the American public was clearly more concerned with illegal law enforcement practices than it had been in years past. Even by the late $1950 \mathrm{~s}$, courts and commentators alike had begun to note the nation's growing unease with unchecked police power. ${ }^{118}$ For the

${ }^{115}$ See Wolf, 338 U.S. at 29 ("The contrariety of views of the States is particularly impressive in view of the careful reconsideration which they have given the problem in the light of the Weeks decision.").

${ }_{176}$ See Weeks v. United States, 232 U.S. 383, 393 (1914) (reasoning that if evidence illegally seized can still be used as evidence, "the protection of the Fourth Amendment, declaring [the] right to be secure against such searches and seizures, is of no value, and, so far as those thus placed are concerned, might as well be stricken from the Constitution").

${ }^{117}$ As Justice Harlan stated in Mapp:

The preservation of a proper balance between state and federal responsibility in the administration of criminal justice demands patience on the part of those who might like to see things move faster among the States in this respect.... For us the question remains, as it has always been, one of state power, not one of passing judgment on the wisdom of one state course or another.

367 U.S. at 680-81 (Harlan, J., dissenting); see also Porter, supra note 54, at 21 (summarizing a speech in which Justice Brennan stated that considerations of federalism had previously prevented the Supreme Court from applying various Bill of Rights safeguards to the states in criminal prosecutions).

${ }^{118}$ See, e.g., Spano v. New York, 360 U.S. 315, 320-21 (1959) (noting "the deeprooted feeling that police must obey the law while enforcing the law; that in the end 
purposes of the present analysis, however, the most interesting commentary on the subject came in 1962, following the Supreme Court's decision in Mapp. Reporting for the New York Times, Anthony Lewis wrote that the Court's efforts to eradicate unfair criminal justice practices "reflect[ed] a national moral sentiment." he went on to write:

Americans [a]re plainly less willing to tolerate police misbehavior in any state, regardless of the political niceties of Federal-state relations, than they were in earlier years. Many Americans have a national conscience that is injured by any state's misbehavior. And more and more the national ideal is prevailing over state orientation. ${ }^{120}$

If Lewis was right, then the Supreme Court's newfound willingness to intervene in matters of state criminal procedure coincided with a readiness among the American public for it to do so. ${ }^{121}$ As such, Mapp may well have reflected an emerging national consensus regarding not only the exclusionary rule, but also the legitimacy of federal intervention in state criminal justice affairs. The intriguing question, again, is why that would have been so. Here the analysis necessarily becomes more speculative, though two developments provide at least part of the explanation.

First, the nation in 1961 was almost certainly still trying to distance itself from the more unpleasant aspects of totalitarian police practices it had witnessed during World War II. Having seen for itself where unrestrained police power could lead, the American public in the late

life and liberty can be as much endangered from illegal methods used to convict those thought to be criminals as from the actual criminals themselves"); People v. Cahan, 82 P.2d 905, 912 (Cal. 1955) (recognizing that "[t]oday one of the foremost public concerns is the police state"); Francis A. Allen, The Supreme Court, Federalism, and State Systems of Criminal Justice, 8 DEPAUL L. REV. 213, 254 (1959) (noting the "quickening public interest in the administration of criminal justice"). An early draft of the Mapp opinion reportedly noted the phenomenon as well. See Schwartz, supra note 111, at 267 (relaying contents of Justice Clark's first Mapp draft, including his reference to "aroused public opinion" on the issue of police discipline).

${ }^{119}$ Anthony Lewis, Historic Change in the Supreme Court, N.Y. TIMEs, June 17, 1962, $\S 6$ (Magazine), at 7 .

${ }^{120} \mathrm{Id}$.

${ }^{121}$ The fact that editorials praised the Court's decision in Mapp, despite the misgivings of police and states' rights advocates, provides at least anecdotal support for Lewis's claim. See, e.g., Editorial, The Individual's Rights, N.Y. TIMES, June 22, 1961, at 30 (arguing that "police illegality can only breed public disrespect for law, and there is no effective way to curb it save by making the evidence inadmissible"); Nathaniel Phillips, Letter to the Editor, Ban on Unlawful Search Hailed, N.Y. TIMES, June 26, 1961, at 30 (describing the ban on evidence obtained by illegal search and seizure as contributing to the nation's image as a champion of individual rights). 
1940s quite naturally developed an "ideological revulsion" against Gestapo-type law enforcement techniques that translated into an ongoing desire to rein in police authority at home. ${ }^{122}$ The ensuing Cold War of the 1950s would have only reinforced this desire as Americans sought to prove to themselves and the rest of the world that democratic freedoms were superior to KGB-enforced communist controls. ${ }^{123}$ And with the national crime rate in 1961 at just $1 \%$ over $1960,{ }^{124}$ there was little to distract the public from the need to more meaningfully safeguard its Fourth Amendment protections.

Second, the nation had become a much more cohesive unit by 1961, and so Americans were more comfortable with the idea of federal intervention in areas traditionally considered to be state affairs. Advances in communication and transportation had given the public an increasingly national perspective and that, in turn, had made increasingly obsolete the notion that criminal defendants could be treated poorly just because it was a state's prerogative. ${ }^{125}$ With charismatic John F. Kennedy's election to the presidency in 1960, the public became even more focused on the national scene, causing the "federalism pendulum" to swing even further away from the states. ${ }^{126}$ By 1961 , then, the legitimacy of using federal power to solve nationwide problems (even those traditionally considered to be local ones) was not in serious dispute.

${ }^{122}$ See Klarman, Rethinking, supra note 2, at 65 (discussing the likely impact of "ideological revulsion against Nazi practices" on criminal procedure norms).

${ }_{123}^{12}$ See id. at 34 (discussing the so-called "Cold War imperative" pushing post-World War II America to demonstrate to the world that democratic capitalism was superior to communism).

${ }^{124}$ FED. BUREAU OF INVESTIGATION, U.S. DEP'T OF JUSTICE, UNIFORM CRIME REPORTS FOR THE UNITED STATES-1961, at 3 (1962). As it turned out, 1961's 1\% increase in crime over 1960 was the lowest of the decade. See infra notes 292, 336, 424 (reporting higher crime rates throughout the mid- to late-1960s).

See GRAHAM, supra note 41 , at 4 ("[D]ifferences from state to state in the treatment of persons who ran afoul of the law had become intolerable in a nation where state lines had come to mean so little."); A. Kenneth Pye, The Warren Court and Criminal Procedure, $67 \mathrm{MICH}$. L. REv. 249, 258 (1968) ("The mere status of being in America should confer protection broad enough to protect any man from the vagaries of a state which by inertia or design fails to keep pace with a national consensus concerning the fundamental rights of the individual in our society."); see also WILLIAM O. DOUGLAS, WE THE JUDGES 42 (1956) ("In America, the trend has been toward the development of a strong and powerful national government.").

${ }^{126}$ See GraHAM, supra note 41, at 16-17 (crediting the election of President John F. Kennedy for "a brief era of immense national faith in the capacity of enlightened and powerful men-especially in Washington-to accomplish reform"). See generally Bacigal, supra note 12 (coining the phrase "federalism pendulum"). 
That said, neither of the above developments provides a fully satisfactory explanation for the nation and Supreme Court's attitudinal shift between the time Wolf and Mapp (and even Irvine and Mapp) were decided. For starters, it was the New Deal of the 1930s that gave the public its confidence in a strong national government, ${ }^{127}$ so to some extent that factor was present when the Court decided Wolf and Irvine as well. Even the incorporation aspect of Mapp was nothing new; by the early 1930s, the Supreme Court had already extended the First Amendment's freedoms of speech, religion and assembly to the states, ${ }^{128}$ incorporating civil rights long before it ever turned to those in the criminal context. Similarly, the nation's recoil against totalitarian-style law enforcement tactics must have also existed when Wolf and Irvine were decided. In fact, given the temporal proximity of both decisions to World War II and the widely publicized Nuremberg trial that followed in 1945-46, ${ }^{129}$ one would think public sentiment would have been just as strong (if not stronger) in the late 1940 s to mid1950 s as it was in the early 1960 s.

Perhaps the most that can be said is that the nation may well have been ready for Mapp's ruling before the Supreme Court was ready to render it. There is reason to believe, however, that another, more recent development was making federal regulation of police conduct particularly attractive to the Supreme Court and many Americansthe burgeoning civil rights movement. Granted, black Americans had made significant strides in racial relations even by the time Wolf and Irvine were decided; as Michael Klarman has persuasively argued, World War II provided the egalitarian social, economic and political conditions that made possible the Court's 1954 decision in Brown $v$. Board of Education. ${ }^{130}$ Still, it was not until after 1954 that the modern civil rights movement truly began. Historically salient events like the 1955-56 Montgomery bus boycotts, the 1957 showdown at Little Rock,

${ }^{127}$ Kermit L. Hall, The Warren Court in Historical Perspective, in THE WARREN COURT: A Retrospective, supra note 52, at 293, 300 (describing the rise of big government as "one of the enduring legacies of the New Deal").

${ }^{128}$ See, e.g., Lovell v. City of Griffin, 303 U.S. 444, 450 (1938) (incorporating the First Amendment's freedom of speech and freedom of the press into the Fourteenth Amendment); De Jonge v. Oregon, 299 U.S. 353, 364 (1937) (incorporating the First Amendment's freedom of assembly into the Fourteenth Amendment).

${ }^{129}$ See Carol S. Steiker, Second Thoughts About First Principles, 107 HARV. L. REV 820, 842 (1994) (discussing the salience of the 1945-46 Nuremberg trial and its impact on Justice Jackson).

${ }_{130}^{130} 347$ U.S. 483 (1954); see Michael J. Klarman, Brown, Racial Change, and the Civil Rights Movement, 80 VA. L. REV. 7 (1994) ("Many of the factors conductive to racial change ... were byproducts of World War II ...."). 
the 1960 sit-ins, and the early 1961 Freedom Rides all occurred between the time Irvine and Mapp were decided; ${ }^{131}$ indeed, in the intervening years between those decisions, Congress passed the first two pieces of civil rights legislation since Reconstruction. ${ }^{132}$ None of this is to say that by 1961, the civil rights movement had taken the country by storm-it would have to wait two more years for that. ${ }^{133}$ But between 1954 and 1961, the nation had begun to undergo fundamental change as the civil rights movement gained momentum.

In two ways, the burgeoning civil rights movement almost certainly influenced the Supreme Court's criminal procedure jurisprudence. First, it gave the Court a good reason not to respect the power of the states to manage their own criminal justice affairs as in years past. States were using their power to discriminate, and the Supreme Court knew it as well as anyone. In the years immediately following Brown, state courts had joined local politicians in doing everything within their power to resist school desegregation; ${ }^{194}$ in one case, a Southern court's obviously obstructive efforts necessitated four trips to the Supreme Court before 1960 for enforcement of an early integration decree. $^{135}$ By the late 1950 s, the Justices were clearly fed up with Southern states' massive resistance to Brown ${ }^{136}$ and that, in turn, made them

131 See JUAN Williams, Eyes ON THE Prize: America's Civil Rights Years, 19541965 , at 59-147 (1988) (providing an in-depth discussion of early events in the civil rights movement).

132 See Civil Rights Act of 1957, Pub. L. No. 85-315, § 101, 71 Stat. 634, 634 (1957) (codified as amended at 42 U.S.C. $\$ 1975(2000)$ ) (creating the U.S. Commission on Civil Rights); Civil Rights Act of 1960, Pub. L. No. 86-449, $\S \S 101-301,74$ Stat. 86, 86-88 (1960) (codified as amended in scattered sections of 18 U.S.C., 20 U.S.C., and 42 U.S.C.)) (establishing penalties for obstruction of court orders, flight to avoid prosecution, and failure to maintain federal election records).

${ }^{133}$ See allen J. Matusow, The UnRaveling of America: a History of LibERALISM IN THE 1960S, at 86-87 (1986) (crediting events in Birmingham in 1963 for creating a mass constituency sympathetic to the civil rights movement); POWE, supra note 12, at 225-26 (recognizing Birmingham as a catalyst for the civil rights movement); Klarman, supra note 130, at 130 (discussing the marked change in Northern, white opinion on the issue of civil rights after Birmingham). Birmingham is discussed infra in note 278 and accompanying text.

${ }^{134}$ See Michal R. BElKNaP, RaCial Violence AND Constitutional CONFlict in THE POST-BROWN SOUTH 121 (1987) (noting that "many [state court] southern judges seemed to view themselves 'less as impartial umpires and dispensers of justice than as defenders of white supremacy'").

${ }^{135}$ See Robert J. Glennon, The Jurisdictional Legacy of the Cixil Rights Movement, 61 TENN. L. REV. 869, 880-84 (1994) (describing Virgil D. Hawkins's attempt to desegregate the University of Florida College of Law).

${ }^{136}$ See generally Numan V. BARTLEY, THE RISE OF MASSIVE RESISTANCE: RACE AND POLITICS IN THE SOUTH DURING THE 1950's (1969) (discussing Southern states' massive resistance to school desegregation). 
highly unreceptive to cries of states' rights. After all, deferring to the states had little appeal when the states were using their power to massively resist a Supreme Court ruling on racial equality. ${ }^{137}$ As Robert Glennon has noted, the Supreme Court's lack of faith in state courts to decide cases in a fair (i.e., nondiscriminatory) manner led to a restricted "adequate and independent state ground" doctrine in the late 1950s. ${ }^{138}$ Given that development and the sentiment driving it, it is not surprising that the Court contemporaneously refused to abide by traditional federalism constraints in other doctrinal areas as well. By 1961, federalism was just enabling local power structures to discriminate against blacks, and that had become unacceptable.

Indeed, in matters regarding the regulation of police conduct, the Supreme Court had even less reason to defer to the states. Police played an integral part in perpetuating racist culture, and as such, Southern states had every reason not to enforce checks on their behavior. It is no coincidence, I believe, that just months before Mapp was decided the Court provided a $\$ 1983$ remedy to victims of police misconduct under facts clearly demonstrating the propensity of police to enforce racist social mores. ${ }^{199}$ By 1961, the U.S. Commission on Civil Rights had been investigating the connection between race and police brutality for two years, ${ }^{140}$ so the notion that law enforcement was being

${ }^{137}$ I credit Michael Klarman for this insight.

138 See Glennon, supra note 135, at 910-11 (discussing the connection between the civil rights movement and the Warren Court's interpretation of the "adequate and independent state ground" doctrine).

${ }^{139}$ See Monroe v. Pape, 365 U.S. 167, 192 (1961) (recognizing a cause of action against police officers in their individual capacity). Dissenting Justice Frankfurter described the facts of the case as follows:

The complaint alleges that on October 29, 1958, at 5:45 a.m., thirteen Chicago police officers, led by Deputy Chief of Detectives Pape, broke through two doors of the Monroe apartment, woke the Monroe couple with flashlights, and forced them at gunpoint to leave their bed and stand naked in the center of the living room; that the officers roused the six Monroe children and herded them into the living room; that Detective Pape struck Mr. Monroe several times with his flashlight, calling him "nigger" and "black boy"; that another officer pushed Mrs. Monroe; that other officers hit and kicked several of the children and pushed them to the floor....

Id. at 203 (Frankfurter, J., dissenting). In response to claims that the Court's ruling would disturb the delicate balance of federal-state relations, the majority stated, "It is no answer that the State has a law which if enforced would give relief. The federal remedy is supplementary to the state remedy, and the [state remedy] need not be first sought and refused before the federal one is invoked." Id. at 183.

${ }^{140} \mathrm{See}$ U.S. COMM'N ON CIVIL RIGHTS, JUSTICE: 1961 COMMISSION ON CIVIL RIGHTS REPORT, at xi (1961) [hereinafter 1961 CIVIL RIGHTS REPORT] (noting that in 1959, the Commission's term was extended so that it could investigate, among other things, 
used to maintain black subordination was hardly anything new. For good reason, then, the Supreme Court may well have concluded that some states would not come around to the exclusionary rule after all. Even the two Southern states that had adopted the exclusionary rule after Wolf did so in 1951, ${ }^{141}$ well before Brown propelled their racial politics to the right. In light of the South's stiffening racist resolve after Brown, ${ }^{142}$ it was almost unfathomable that any Southern state in the mid- to late-1950s would have taken action to curb police excesses on its own.

In sum, one thing the burgeoning civil rights movement did was give the Supreme Court a reason to distrust the states, especially on matters of criminal procedure. Yet the nation's growing interest in protecting black Americans did something else too: it gave the Court a reason to take an interest in criminal defendants. Whether or not the Supreme Court was consciously thinking about racial discrimination under the facts of Mapp, it knew from prior cases that the most egregious abuses of police power were perpetrated against blacks, ${ }^{143}$ and that to the extent its ruling corrected an injustice, it would have the most impact there. ${ }^{144}$ With the civil rights movement gaining momentum, it was only natural for the Supreme Court to launch a criminal procedure revolution when it did-criminal defendants were treated horribly in certain jurisdictions, and a disproportionate number of them were black. ${ }^{145}$ Perhaps, then, the best explanation for

racial discrimination in the administration of justice). The Commission's report, which was issued several months after Mapp was decided, concluded that "police brutality in the United States today is a serious and continuing problem in many parts of the country .... The statistics suggest that Negroes feel the brunt of official brutality proportionately more than any other group in American society." Id. at 26-27.

${ }^{141}$ See supra note 103 and accompanying text (discussing Alabama and North Carolina's change of stance on the exclusionary rule between the time Wolf and Mapp were decided).

${ }^{142}$ See Klarman, supra note 130, at 85-149 (discussing the Brown backlash thesis).

${ }^{143}$ For an excellent discussion of the connection between race and the Court's earliest criminal procedure cases, see Klarman, Racial Origins, supra note 13, at 50-77.

${ }^{144}$ As Lewis Katz has noted:

The impact of Mapp was naturally greatest in the African-American community where Fourth Amendment violations were the most common. Whatever limited effect Mapp would have, it would be felt most where police conduct was the least restrained. It was this community which the Warren Court intended to benefit by the due process revolution, because wherever injustice existed in America, its worst impact was felt in the black community.

Lewis R. Katz, Mapp After Forty Years: Its Impact on Race in America, 52 CASE W. RES. L. REV. 471, 482 (2001).

${ }^{145}$ See supra note 55 (describing the typical criminal defendant). 
Mapp and the revolution it inaugurated comes from the words of Archibald Cox: "Once loosed, the idea of [e]quality is not easily cabined." ${ }^{146}$ After Brown gave blacks equality in education, it was only a matter of time before the Supreme Court would turn to racial equality in other contexts, such as criminal procedure. ${ }^{147}$ Indeed, as the civil rights movement gained momentum, the notion that blacks should be protected in their civil rights, but not when their liberty and lives were at stake, must have seemed patently absurd.

Thus, for several reasons, 1961 presented a much more favorable climate to launch a criminal procedure revolution, starting with restraints on police power, than had earlier years. By that year, a solid half of the states (and counting) had already adopted the exclusionary rule on their own. ${ }^{148}$ Moreover, by 1961 , the nation as a whole was less tolerant of local law enforcement abuses and more receptive to the notion of federal intervention in traditional state affairs. The Supreme Court's decision in Mapp reflects these developments. In $M a p p$, the Court took power from the states at a time when the states could not be trusted and protected blacks at a time when the nation was awakening to the need to protect them. As such, the common conception of Mapp as an aggressively countermajoritarian decision is simply inaccurate. That said, Mapp was still not the enormously popular decision that would come next among the landmark cases of the revolution, Gideon v. Wainuright. ${ }^{149}$

\section{Gideon v. Wainwright: A Piece of Storybook Americana}

Decided in March 1963, Gideon v. Wainwright incorporated the Sixth Amendment right to counsel to the states, entitling all indigent felony defendants to a court-appointed attorney. ${ }^{150}$ In so doing, the Court in Gideon overruled its 1942 decision in Betts $v$. Brady ${ }^{151}$ and erased any doubts that a revolution in criminal procedure had begun. Unquestionably, Gideon was one of the most monumental criminal procedure cases ever decided-it guaranteed to state felony defendants "the most pervasive right," the one right defendants must have

146 Archibald CoX, The Warren Court 6 (1968).

147 See Pye, supra note 125 , at 256 ("Concern with civil rights almost inevitably required attention to the rights of defendants in criminal cases.").

${ }^{148}$ See supra notes 101-06 and accompanying text (discussing the trend among the states toward adoption of the exclusionary rule).

149372 U.S. 335 (1963).

${ }^{150} I d$. at 345 .

151316 U.S. 455 (1942). 
in order to meaningfully exercise any others. ${ }^{152}$ Moreover, because the vast majority of criminal defendants are indigent, ${ }^{153}$ Gideon's potential impact on the administration of criminal justice was truly astounding. Presumably for these reasons, Earl Warren considered Gideon to be the most important criminal procedure case his Court had decided and the third most important case of his tenure overall. ${ }^{154}$

As important as it was, however, Gideon merits a place in the present analysis for another reason: it has been canonized by popular culture as a classic example of the Supreme Court's heroic, countermajoritarian role in the criminal procedure revolution. ${ }^{155}$ In part, Gideon's acclaim stems from the holding of the case-that even the poor are entitled to an attorney's help when faced with serious criminal charges. In part, however, Gideon's fame stems from the facts of the case itself. Clarence Earl Gideon was by all accounts "the least among men," a 51-year-old drifter with nothing more than an eighthgrade education and four felony convictions to his name. ${ }^{156}$ Gideon was not the dangerous sort, just a small-time gambler and thief; those who would later write about him would say he was "a perfectly harmless human being, rather likeable, but one tossed aside by life."157

${ }^{152}$ Yale Kamisar, The Right to Counsel and the Fourteenth Amendment: A Dialogue on "The Most Pervasive Right" of an Accused, 30 U. CHI. L. REV. 1, 9 (1962).

${ }^{159}$ See Criminal Justice: Concern About Confessions, TIME, Apr. 29, 1966, at 52, 53 (noting that $60 \%$ of criminal defendants could not afford lawyers); supra note 55 and accompanying text (describing characteristics of a typical criminal defendant).

${ }_{154}$ Only the school desegregation and reapportionment cases ranked higher. See Leonard W. Levy, Introduction to THE SUPREME COURT UNDER EARL WARREN, supra note 29, at 3, 20 (discussing Earl Warren's ranking of cases in order of importance).

${ }^{155}$ See infra notes 161-62 and accompanying text (mentioning popular conceptions of Gideon); see also Gideon's Trumpet: The Poor Man and the Law (CBS News television broadcast, Oct. 7, 1964); infra note 157 (recounting depiction of Gideon in Gideon's Trumpet).

${ }^{156}$ CRAY, supra note 59, at 405 .

157 ANTHONY LEWIS, GIDEON'S TRUMPET 6 (1964). Lewis' full introduction on Gideon was as follows:

Gideon was a fifty-one-year-old white man who had been in and out of prisons much of his life. He had served time for four previous felonies, and he bore the physical marks of a destitute life: a wrinkled, prematurely aged face, a voice and hands that trembled, a frail body, white hair. He had never been a professional criminal or a man of violence; he just could not seem to settle down to work, and so he had made his way by gambling and occasional thefts. Those who had known him, even the men who had arrested him and those who were now his jailers, considered Gideon a perfectly harmless human being, rather likeable, but one tossed aside by life. Anyone meeting him for the first time would be likely to regard him as the most wretched of men.

Id. at 5-6. 
When he was charged with breaking and entering a Panama City, Florida, poolroom, Gideon requested a court-appointed attorney to represent him at trial. The trial court denied his request. In the colloquy that has since become famous, Gideon challenged the trial court, claiming (mistakenly at the time), "the United States Supreme Court says I am entitled to be represented by [c]ounsel." ${ }^{158}$ Again, the trial court denied his request. Gideon went to trial without an attorney and was promptly convicted of the felony charge, receiving a five-year sentence. Having time on his hands and some experience in jailhouse legal matters, Gideon fastidiously pursued an appeal of his case, ultimately penciling a certiorari petition to the Supreme Court on lined sheets of paper from the Florida prison where he resided. All things considered, the Court could not have found a more perfect case to defend indigent felony defendants had it been looking for one-and the little-known truth is, it had been. ${ }^{159}$

The rest, as they say, is history. The Supreme Court granted certiorari in Gideon's case and appointed one of Washington's most prominent lawyers, Abe Fortas, to argue on his behalf. ${ }^{160}$ It then vindicated Gideon's faith in the Court, refusing to allow the vagaries of personal finances determine a felony defendant's chances of prevailing at trial. As Earl Warren's biographer, Ed Cray, would later write, Gideon was "a piece of storybook Americana .... No tale so affirmed the American democracy. No story broadcast around the world so clearly proclaimed that not just the rich received justice in American courts." ${ }^{161}$ Even last year, as Gideon celebrated its fortieth anniversary, scholars reminisced about the pride they felt when the highest court of the land reached down to rescue the quintessential little man,

${ }^{158}$ The Supreme Court's opinion in Gideon quoted the passage, and CBS reenacted the colloquy in its special broadcast of the case, using the actual trial judge and Gideon himself as actors. Gideon v. Wainwright, 372 U.S. 335, 337 (1963); Gideon's Trumpet: The Poor Man and the Law, supra note 155.

${ }^{159}$ Chief Justice Warren reportedly directed his clerks to search for a good case to overrule Betts, passing by the opportunity in Carnley $v$. Cochran, 369 U.S. 506 (1962), because the defendant in that case was charged with incestuous sexual intercourse with his 13-year-old daughter. See PowE, supra note 12, at 381-82 (discussing Carnley and relaying Justice Frankfurter's comment that he could not "imagine a worse case, a more unsavory case to overrule a long standing decision'" (quoting SCHWARTZ, supra note 62, at 408)); UROFSKY, supra note 34, at 172 (describing the Court's decision not to use Camley to overrule Betts as an indication that the Court "controls its docket as well as its image").

${ }_{160}$ Gideon v. Cochran, 370 U.S. 932 (1962) (order appointing Abe Fortas as counsel to Gideon).

${ }^{161}$ CRAY, supra note 59 , at 405-06. 
Clarence Gideon. ${ }^{162}$ If ever the Supreme Court played the role of countermajoritarian hero, surely it played it here--or so we think.

Although Gideon was undoubtedly a heroic decision, our common perception of the Supreme Court's role there is only partly right; the Court may have rescued Gideon from the State of Florida, but it was hardly acting in the countermajoritarian fashion we tend to associate with the case. By the time the Court decided Gideon, all but five states-Florida, Alabama, Mississippi, North Carolina, and South Carolina-already provided counsel to indigent felony defendants, and those five were a less than prestigious lot in $1963 .{ }^{163}$ Even Florida provided counsel to indigent felony defendants in certain localities; it just so happened that Panama City was not one of them. ${ }^{164}$ Equally, if not more, telling of the nature of the Supreme Court's decision in Gideon was the fact that twenty-two state attorneys general joined together to file an amicus curiae brief on Gideon's behalf; Florida, by contrast, could muster only two to support its position. ${ }^{165}$ As contemporary observers recognized, it was nothing short of extraordinary for the top law enforcement officials of so many states to ask the Court to impose upon them a constitutional protection for criminal defendants. $^{166}$

Given the states' position on the issue, it should come as no surprise that Gideon was one of the most popular cases of the Warren Court era. Newspaper and television coverage praised the decision, ${ }^{167}$ as did the law review literature, which had long advocated that Betts $v$.

${ }^{162}$ See, e.g., Yale Kamisar, Gideon's Unkept Promise, NAT'L L.J., Mar. 17, 2003, at A12 ("Most of us experienced a surge of pride when the highest court of the land reached down to hear this little man's case ....").

${ }^{163}$ PowE, supra note 12, at 380; see also Kamisar, supra note 152, at 17-19 (detailing the breakdown of state practices on the issue).

${ }^{164}$ CRAY, supra note 59, at 403-04.

165 The Attorney General of Oregon filed a separate amicus brief on Gideon's behalf, for a total of twenty-three states supporting the Court's ruling. Only Alabama and North Carolina filed an amicus brief supporting the State of Florida. Gideon v. Wainwright, 372 U.S. 335, 335-36 (1963).

${ }_{166}$ See, e.g., Anthony Lewis, The Criminal Law Cases: Supreme Court Rulings on Counsel and Other Points Pose Problems, N.Y. TIMES, Mar. 21, 1963, at 6 [hereinafter Lewis, The Criminal Law Cases] (describing position of the twenty-two attorneys general in Gideon as "an extraordinary event in the Court's history"); Anthony Lewis, Supreme Court Changes Again, N.Y. Times, Mar. 25, 1963, at 12 [hereinafter Lewis, Supreme Court Changes Again] (describing same as "most unusual").

${ }^{167}$ See, e.g., Lewis, The Criminal Law Cases, supra note 166, at 6; Gideon's Trumpet: The Poor Man and the Law, supra note 155; see also PowE, supra note 12, at 381 (quoting an editorial from the Washington Post praising the Gideon decision). 
Brady be overruled. ${ }^{168}$ Even the American Bar Association strongly supported Gideon, a remarkable endorsement given its previously critical stance on Supreme Court decisions that took power from the states. ${ }^{169}$ Gideon was so appealing, in fact, that it quickly became a part of pop culture, inspiring the best-selling novel Gideon's Trumpet ${ }^{170}$ in 1964 and, much later, a prime-time television movie with a handsome Henry Fonda playing the downtrodden Gideon role. ${ }^{171}$

Among the Supreme Court Justices, too, Gideon was a popular decision. Indeed, of the five landmark cases discussed in this paper, it is the only one to have received the Justices' unanimous support, providing yet another indication of just how mainstream the Court's ruling was by 1963. Conservative Justices Clark and Harlan both had little difficulty voting to overrule Betts; in conference, Justice Harlan reportedly went so far as to say, "[Betts] is a freak, and we should get done with it." known for launching a "counter-revolution" in criminal procedure ${ }^{173}$ - would embrace Gideon, unanimously extending its holding to misdemeanor cases where the defendant received jail time. ${ }^{174}$ In short, Gideon's holding was agreeable to just about everyone, both in 1963 and in later, more conservative years.

Granted, much of Gideon's appeal for the Warren Court Justices and others had to do with the doctrinal landscape at the time it was decided. Although Betts required the states to provide counsel to

168 See CRAY, supra note 59, at 404 (noting that "the legal profession had long held [Betts] in faint regard, the law journals in even lower repute"); Kamisar, supra note 162, at A12 (noting that Gideon "was widely applauded by both the legal profession and the general public"); Lewis, Supreme Court Changes Again, supra note 166, at 6 (noting that Betts had been "subjected to unrelenting attack in the law reviews").

${ }^{169}$ See Counsel for Poor Acclaimed by Bar, N.Y. TIMES, Mar. 22, 1963, at 5 (noting "strong support" for Gideon from the American Bar Association); supra text accompanying note 68 (quoting the American Bar Association President's criticism of Mapp on federalism grounds).

${ }^{170}$ LEWIS, supra note 157.

${ }^{171}$ See John J. O'Connor, TV: 'Gideon's Trumpet,'Landmark Rights Case, N.Y. TIMES, Apr. 30, 1980, at C30 (describing the movie as "absorbing" and Henry Fonda's performance as "utterly convincing").

${ }^{172}$ The Supreme Court IN CONFERENCE, supra note 86, at 503. Publicly, Justice Harlan took a slightly different stance, stating that he believed Betts was "entitled to a more respectful burial" than the majority's opinion in Gideon had given it. Gideon, 372 U.S. at 349 (Harlan, J., concurring).

${ }^{173}$ See generally THE BURger COURT: THE COUNTER-REvOlution THAT WASN'T (Vincent Blasi ed., 1983).

${ }^{174}$ See Argersinger v. Hamlin, 407 U.S. 25, 32-33 (1972) (recognizing a criminal defendant's right to counsel if punished with incarceration). 
indigent felony defendants only in "special circumstances,"175 the Court had found special circumstances present in every case it had reviewed after $1950 .{ }^{176}$ By the time the Supreme Court decided Gideon, it had even recognized as a special circumstance the complexity of legal issues involved, though lawyers would have found those issues to be "of only routine difficulty." Cli77 ize that a felony charge was, like a capital charge, its own special circumstance-a situation sufficiently perilous to justify the right to counsel. That being the case, it was easy to see why so many states urged the Court to overrule Betts and formalize the bright-line rule it had already implicitly adopted: more federal intrusion would actually mean less. ${ }^{178}$

Equally significant were developments in the Supreme Court's appellate criminal procedure jurisprudence. In 1956, the Court had held that indigent defendants were entitled to a free transcript on appeal, ${ }^{179}$ leaving little doubt among commentators that indigent defendants were entitled to an attorney on appeal as well. ${ }^{180}$ Indeed, as Scott Powe's research has revealed, a majority of the Justices had already agreed on the right to appellate counsel in another case,

${ }^{175}$ See LAFAVE ET AL., supra note 46, at 555-56 (discussing Betts's "special circumstances" test ).

${ }^{176}$ See Gideon, 372 U.S. at 350-51 (Harlan, J., concurring) (noting that in no decision after Quicksall v. Michigan, 339 U.S. 660 (1950), had the Court found special circumstances lacking).

${ }^{177}$ See id. at 351 (Harlan, J., concurring) ("At the same time, there have been not a few cases in which special circumstances were found in little or nothing more than the 'complexity' of the legal questions presented, although those questions were often of only routine difficulty." (footnote omitted)).

${ }^{178}$ See Jerold H. ISRael et al., Criminal Procedure and the Constitution: LEADING SUPREME COURT CASES AND INTRODUCTORY TEXT 274 (2000) (noting that Betts' special circumstances rule was less, rather than more, consistent with federalism principles given the proliferation of habeas corpus cases it produced and the resulting friction between state and federal courts). Future Justice Abe Fortas made the same point in an interview with CBS News. See Gideon's Trumpet: The Poor Man and the Law, supra note 155 .

${ }^{179}$ See Griffin v. Illinois, 351 U.S. 12, 19 (1956) (requiring the provision of trial transcripts for indigent defendants appealing their conviction).

${ }^{180}$ See Francis A. Allen, Griffin v. Illinois: Antecedents and Aftermath, 25 U. CHI. L. REV. 151, 170-71 (1957) (noting that Griffin's rationale "is very suggestive of a forthcoming requirement that indigents be furnished with counsel for an appeal"); R.D. Hursh, Annotation, Right of Indigent Defendant in Criminal Case to Aid of State as Regards New Trial or Appeal, 55 A.L.R.2D 1072, 1085 (1957) (noting that the right to counsel for indigent defendants on appeal addresses the same problem as Griffin and therefore "would appear to be no more than a logical extension of the Griffin doctrine"). 
Douglas v. Califormia, ${ }^{181}$ well before Gideon was briefed and argued. ${ }^{182}$ Naturally, if indigent defendants had a right to counsel on appeal, they also had a right to counsel at trial, which perhaps explains why the Court carried Douglas over to the following term and decided it the same day as Gideon. ${ }^{183}$ In retrospect, then, Abe Fortas had the notso-difficult job of convincing the Supreme Court to do what it was going to do anyway. No wonder Justice Douglas would remember Fortas' presentation as "the best single legal argument" he had heard in his thirty-six years on the bench; ${ }^{184}$ Gideon himself could have argued the case and still won without a fight. ${ }^{185}$

No doubt, Gideon's doctrinal inevitability explains much of its appeal among conservatives and law enforcement officials, yet there must have been more to it than that. Justice Harlan privately surmised that he would have been among the Betts dissenters in 1942, ${ }^{186}$ and the state attorneys general shared that sentiment, describing Betts as "'an anachronism when handed down." "187 The Court's opinion in Gideon also took the position that Betts was wrong when it was decided, ${ }^{188}$ so Gideon's holding must have been more than just a product of doctrinal attrition. Changing ideology played a role too; in fact, that was most likely the reason the Court's jurisprudence had strayed from Betts in the first place. By 1963, however, it was only natural for the Justices to support the provision of counsel for indigent felony defendants as a matter of principle, and not just precedent. At the time, it was considered almost immoral not to. ${ }^{189}$ To understand why, one

181372 U.S. 353,355 (1963).

${ }^{182}$ The Justices had agreed upon the result and rationale of Douglas in June 1962, the same month the Court granted certiorari in Gideon. For an excellent discussion of the timing of events in the two cases, see POWE, supra note 12, at 381-85.

${ }^{183}$ Both cases were decided on March 18, 1963. Id. at 384 .

${ }^{184}$ THE SUPREME COURT IN CONFERENCE, supra note 86, at 502.

185 See POWE, supra note 12, at 385 ("[W]ith Douglas in existence (although not publicly), Gideon could have argued Gideon and won 9-0.”).

${ }^{186}$ See The Supreme COURT IN CONFERENCE, supra note 86, at 503 (reproducing the Conference notes on Gideon).

${ }^{187}$ See Gideon, 372 U.S. at 345 (quoting the state attorney generals' amicus brief with approval).

188 See id. at 342 "We think the Court in Betts was wrong, however, in concluding that the Sixth Amendment's guarantee of counsel is not one of these fundamental rights."); id. at 344 ("[I]n our adversary system of criminal justice, any person haled into court, who is too poor to hire a lawyer, cannot be assured a fair trial unless counsel is provided for him. This seems to us to be an obvious truth.").

${ }^{189}$ See LIVA BAKER, MIRANDA: CRIME, LAW AND POLITICS 82 (1983) ("[T]alking against the obligation of a democratic society to provide a fair trial for a poor, uneducated fellow seemed immoral."); Lewis, The Criminal Law Cases, supra note 166, at 6 
must again turn to the extralegal context in which the Court was operating.

Much of what has already been discussed regarding the impact of the civil rights movement on the Supreme Court's decision in Mapp applies with equal, if not more, force to its decision in Gideon just two years later. Though the events in Birmingham were still a month away when Gideon was decided, ${ }^{190}$ the civil rights movement had gained substantial support by the beginning of 1963 and the plight of black defendants in Southern courts had already begun to receive publicity. ${ }^{191}$ No doubt, the Supreme Court was thinking about the right to counsel in light of these developments; Gideon happened to be white, but the fact that only Southern states had refused to provide an attorney to indigent felony defendants made the connection impossible to ignore. For a Court presumably interested in protecting blacks from Jim Crow justice, extending the right to counsel to the states was attractive for two reasons. First and most obvious, it gave black defendants a sorely needed legal advocate to argue on their behalf. Second, and perhaps less obvious, it increased the opportunities for judicial oversight of suspect Southern courts. Appellate review of a defendant's conviction did little good if someone was not making motions and objections at the trial level, and most defendants needed an attorney to make that happen. In that regard, the Court's decision in Gideon served the same purpose as its habeas corpus ruling in Fay $v$. Noia, ${ }^{192}$ which coincidentally (or not) was decided the same day: both

("The idea that a man should be forced to undergo a criminal prosecution without a lawyer's help simply because he is poor seems to offend nearly everyone's sense of justice.").

${ }^{190}$ See supra note 133 (discussing the importance of Birmingham to the civil rights movement).

${ }^{191}$ See, e.g., Claude Sitton, When a Southern Negro Goes to Court, N.Y. TIMES, Jan. 7, $1962, \S 6$ (Magazine), at 10 (discussing the treatment of blacks in and out of Southern courtrooms); see also MATUSOW, supra note 133, at 85-86 (noting that eighty-nine members of the House of Representatives submitted civil rights bills at the beginning of the new congressional session in 1963). Events contributing to the movement's growing success included the Freedom Rides of 1961 and the admission of James Meredith into Ole Miss in 1962, along with the racist resistance those events provoked. For an in-depth discussion of those events, see WILLIAMS, supra note 131, at 144-61, 213-18.

372 U.S. 391, 438 (1963) (holding that federal habeas corpus is available even to those who procedurally defaulted their claims so long as state courts were not deliberately bypassed). 
cases allowed federal courts to more easily scrutinize the treatment of black defendants by Southern criminal justice systems. ${ }^{193}$

Even so, the civil rights movement was not the only factor contributing to the Court's ideological shift in favor of the right to counsel. By the late 1950 s, the problem of poverty had begun to infiltrate the American consciousness, and with Michael Harrington's publication of The Other America in 1962, it moved to America's conscience as well. ${ }^{194}$ By all accounts, Harrington's book had an enormous impact on the national mood, ${ }^{195}$ though by 1962, Americans were in the mood to be sympathetic to the plight of poverty anyway. The late 1950 s to early 1960 s marked one of the strongest peacetime economies in recorded business cycle history, with record-breaking profits and wages as high as anyone could remember. ${ }^{196}$ At the same time, Americans were only a generation away from the Great Depression of the 1930s, so many knew how it felt to be poor through no fault of their own. In short, the early 1960s were a perfect time for the nation to turn its attention to the problem of poverty: the American public had wealth and was relatively open to the idea of sharing it.

As one might expect, the plight of poverty had captured the attention of majoritarian politics by the early 1960 s as well. Though Lyndon B. Johnson would not formally declare war on poverty until January $1964,{ }^{197}$ the executive branch began to focus on the problem as early as 1960 , when John F. Kennedy campaigned on the country's

${ }^{193}$ The Supreme Court itself later recognized this point. See Stone v. Powell, 428 U.S. 465, 493 n.35 (1976) (noting "the unsympathetic attitude to federal constitutional claims of some state judges in years past").

${ }^{194}$ See ARThur M. SCHLesinger JR., A Thousand Days: JOHN F. KEnNEdy IN THE WHITE HOUSE 1010 (1965) (crediting John Kenneth Galbraith's The Affluent Society in 1958 for bringing poverty to the national consciousness and Michael Harrington's The Other America in 1962 for placing it on the national conscience).

${ }^{195}$ See David Zarefsky, President Johnson's WAR ON POVERTY: RHetoric AND HISTORY 24-25 (1986) (characterizing The Other America as "the most significant event in making the general public aware of poverty"); see also Dwight MacDonald, Our Invisible Poor, NEW YORKER, Jan. 19, 1963, at 84 (reviewing The Other America and noting that " $[\mathrm{i}] \mathrm{n}$ the last year we seem to have suddenly awakened, rubbing our eyes like Rip van Winkle, to the fact that mass poverty persists, and that it is one of our ... gravest social problems").

${ }^{196}$ See MATUSOW, supra note 133, at 126-27 (noting that " $[\mathrm{t}]$ he era's affluence spawned both social optimism and the revenues to pay for modest new welfare measures"); SCHLESINGER, supra note 194, at 1012 (discussing economic strength of country in Kennedy years).

${ }^{197}$ President Lyndon B. Johnson, Annual Message to Congress on the State of the Union (Jan. 8. 1964), in PUB. PAPERS 112, 114 ("This administration today, here and now, declares unconditional war on poverty in America."). 
callous disregard for its poor. ${ }^{198}$ In 1961, the Kennedy Administration turned specifically to problems faced by poor criminal defendants, establishing the Attorney General's Committee on Poverty and the Administration of Federal Criminal Justice-better known as the Allen Committee for its prestigious chairman, Francis A. Allen. ${ }^{199}$ In 1963, just weeks before Gideon was decided, the Allen Committee reported its findings. Presuming at the outset that poverty should be irrelevant in any "civilized administration of justice," the Committee recommended, among other things, federal legislation to adequately fund representation for indigent criminal defendants in federal courts. ${ }^{200}$ With the executive branch contemplating ways to ensure that the poor received assistance of counsel in federal courts, the Supreme Court had even more reason (as if it needed one) to do the same at the state level, where it mattered most.

Thus, for several reasons, Gideon was anything but an example of the Supreme Court swooping down to protect the underdog in the face of great opposition. Indeed, in light of the sociopolitical context of 1963, it is difficult to imagine the Court in Gideon not ruling as it did. In Gideon, the Supreme Court validated a well-established national consensus, suppressing Southern states that were out-of-step with the rest of the country's enlightened sense of fairness and equality by the early $1960 \mathrm{~s}$. As others have noted, this was the Warren Court's signature role. ${ }^{201}$ Still, it is more than a little ironic that the same legal assistance at issue in the Warren Court's most popular paign:

${ }^{198}$ Arthur Schlesinger vividly described this theme in Kennedy's presidential cam-

[T] he message of Kennedy's 1960 campaign had been that the American way of life was in terrible shape, that our economy was slowing down, that we were neglectful of our young and our old, callous toward our poor and our minorities, that our cities and schools and landscapes were a mess, that our motives were materialistic and ignoble and that we were fast becoming a country without purpose and without ideals.

SCHLESINGER, supra note 194, at 726.

199 See REPORT OF THE ATTORNEY GENERAL'S COMMITTEE ON POVERTY AND THE ADMINiSTRATION OF FEDERAL CRIMINAL JUSTICE, at $i, 1$ (1963) [hereinafter ALlEN REPORT] (relaying the Committee's mission); see also BAKER, supra note 189, at 15-16 (discussing the Kennedy Administration's "appointment of a Committee on Poverty and the Administration of Criminal Justice-known as the Allen Committee for its chairman, Francis A. Allen of the University of Michigan Law School-to evaluate the quality of justice being offered [to] the poor in the courts"); Kamisar, supra note 52, at $76 \mathrm{n} .233$ (referring to the Allen Report).

200 See ALLEN REPORT, supra note 199, at iv-ix, 5-6.

${ }^{201}$ See, e.g., PowE, supra note 12, at 490 ("In fact, the dominant motif of the Warren Court is an assault on the South as a unique legal and cultural region.”). 
criminal procedure decision would also become the subject of its least popular criminal procedure decision three years later, Miranda $v$. Arizona. ${ }^{202}$

\section{Miranda V. ARIzona: The EXCEPtion That Proves the Rule}

Of the five decisions considered in this analysis, Miranda $v$. Arizona comes closest to realizing the heroic, countermajoritarian ideal we tend to associate with the criminal procedure revolution. Scholars have long regarded Miranda as a symbol of countermajoritarian decision making and controversy, the epitome of all that was wrong (and right) with the Warren Court's activism in the criminal justice arena. ${ }^{203}$ Indeed, Miranda may even be the most countermajoritarian criminal procedure decision in Supreme Court history. In June 1966, when Miranda was decided, only three states required police to warn suspects of their rights prior to custodial interrogation. ${ }^{204}$ Moreover, twenty-six state attorneys general filed an amicus brief in Miranda asking the Supreme Court not to impose any new constitutional restrictions on the admissibility of confessions-a complete 180-degree turn from the support the Court enjoyed when it decided Gideon just a few years earlier. ${ }^{205}$ Police across the country complained bitterly about the Court's holding in Miranda, ${ }^{206}$ and they were not alone in their displeasure. Prominent public opinion polls reported Americans'

${ }^{202} 384$ U.S. 436 (1966).

${ }^{209}$ See POWE, supra note 12, at 394 ("If Miranda is not the most controversial decision by the Warren Court, it is close enough, and it is the most controversial criminal procedure decision hands down ...."); Martin H. Belsky, Whither Miranda, 62 TEx. L. REV. 1341, 1341 (1984) (reviewing BAKER, supra note 189) ("In the second half of the 1960 s, the case of Miranda $v$. Arizona became a symbol of much that was wrong with our criminal justice system and perhaps with society in general."); Alfredo Garcia, Is Miranda Dead, Was It Overruled, or Is It Irrelevant?, 10 ST. THOMAS L. REV. 461, 477 (1998) (describing Miranda as "the archetypal symbol of the Warren Court's excesses in expanding the constitutional rights of criminals"); Richard A. Leo, The Impact of Miranda Revisited, 86 J. CRIM. L. \& CRIMINOLOGY 621, 666 (1996) ("Miranda has been the most celebrated and most reviled Supreme Court case in the history of American criminal justice."); see also OFFICE OF LEGAL POLICY, U.S. DEP'T OF JUSTICE, REPORT TO THE ATtOrney GENERAL: THE LAW OF PRE-TRIAL INTERROGation 119 (1986) (referring to Miranda's "symbolic status as the epitome of Warren Court activism in the criminal law area").

${ }^{204}$ Infra note 254 and accompanying text.

${ }^{205}$ Supra note 165 and accompanying text; infra note 305 and accompanying text.

${ }^{206}$ See infra notes 307-10 and accompanying text (discussing the reaction of police to Miranda). 
disapproval of the decision by a two-to-one margin. ${ }^{207}$ By 1968, Miranda was so unpopular that Congress legislatively overruled it (or at least tried), and Richard Nixon made it a prominent part of his "law and order" presidential campaign. ${ }^{208}$ With all that in mind, how could Miranda not prove the Court's inclination for countermajoritarian decision making?

In all fairness, perhaps it does-at least if the relevant benchmark is what the states were doing when Miranda was decided. Yet the closer one looks, the clearer it becomes that Miranda, too, was a product of its time and well within the parameters of publicly acceptable responses to the problem of coercive police interrogation. As discussed below, Miranda may have been controversial, but it was not the wildly countermajoritarian decision scholars have heretofore thought it to be. Like the other cases discussed in this Article, Miranda makes sense once placed in proper historical context, and that begins with an understanding of the Court's prior attempts to curb coercive police interrogation.

\section{A. Pre-Miranda Attempts to Curb Coercive Police Interrogation}

In its 1936 decision of Brown v. Mississippi, ${ }^{209}$ the Supreme Court first addressed the problem of coercive police interrogation, also known as the "third degree." Brown were perfectly suited for the task. ${ }^{211}$ In Brown, the police whipped three black sharecroppers, repeatedly hanging one of them from a tree, until they confessed to murdering their white landlord. ${ }^{212}$

${ }^{207}$ See infra notes 311-19 and accompanying text (describing public opinion poll data regarding Miranda).

${ }^{208}$ See infra notes 322-31 and accompanying text (discussing Miranda's role in the 1968 presidential election campaign and legislation purporting to overrule it).

${ }^{209} 297$ U.S. 278 (1936).

${ }^{210}$ The phrase "the third degree" generally refers to the infliction of pain to extract statements from a person against that person's will. See WALKER, supra note 108, at 174 (discussing various physical measures and sexual indignities used by police employing "third degree" methods); Peter Carlson, You Have the Right to Remain Silent . ., WASH. PoST, Sept. 13, 1998 (Magazine), at 6 (same). At least one commentator has claimed that the term "third degree" came from Russian police procedures, which reportedly had three degrees-first, cross-examination; second, confrontation; and third, physical duress. See BradLeY, supra note 14, at 13 n.* (1993) (noting the possible origins of the phrase the "third degree").

211 See, e.g., Klarman, Racial Origins, supra note 13, at 68 (noting that Brown "involved an especially appealing set of facts in which to create a new constitutional right"). 
At trial, a deputy sheriff admitted to the whippings but claimed they were "not too much for a Negro." 213 The Mississippi Supreme Court affirmed the convictions, but the United States Supreme Court reversed, interpreting the Fourteenth Amendment's Due Process Clause to preclude the use of convictions that relied on confessions extracted by brutality and violence. ${ }^{214}$ In so doing, the Court established a "voluntariness" standard for determining the admissibility of policeprocured confessions. $^{215}$

In 1936, Brown was a major doctrinal move for the Supreme Court, though even then its interference with state criminal procedure was anything but countermajoritarian. Every state to consider the issue, including Mississippi, had already agreed on the general principle that coerced confessions were inadmissible, so the Court was only holding the states to a standard they themselves purported to employ. ${ }^{216}$ Even so, Brown's voluntariness standard did not accomplish much either. The most immediate effect of the decision was to discourage law enforcement officials from candidly reporting the circumstances of interrogation, ${ }^{217}$ leaving trial courts to decide the issue based on credibility determinations. With predominantly black defendants pitted against predominantly white officers, the results were generally as one might predict.

Years passed, but the problem of coerced confessions did not. By the early 1960s, the Supreme Court had nearly three decades of experience with the voluntariness standard and had developed a long list of factors (thirty-some in all) relevant to the determination of whether a defendant's confession was freely given. ${ }^{218}$ Some of those factors looked at the defendant's personal characteristics, such as age, intelligence, and education, while others looked at the circumstances of the interrogation, such as its length and whether the defendant had been

${ }^{213}$ Id. at 284.

${ }^{214}$ See id. at 286 ("And the trial equally is a mere pretense where the state authorities have contrived a conviction resting solely upon confessions obtained by violence.... [T] he use of the confessions thus obtained as the basis for conviction and sentence was a clear denial of due process.").

${ }^{215}$ See LAFAVE ET AL., supra note 41, at 311-12 (discussing Brown's voluntariness requirement).

${ }^{216}$ See Klarman, Racial Origins, supra note 13, at 67-68 (“[T] he new federal constitutional right identified by the Court... already was recognized by the law of every state.").

${ }^{217} I d$. at 83.

${ }^{218}$ See Criminal Justice: Concern About Confessions, supra note 153, at 57 ("To weigh 'totality,' the court developed no fewer than 38 criteria ....."). 
denied food, sleep, or access to an attorney upon request. ${ }^{219}$ None proved to be particularly helpful. In 1961, a highly publicized Civil Rights Commission Report found that police brutality in obtaining confessions remained a "serious problem" throughout the country, especially among black defendants. ${ }^{220}$ Meanwhile, state courts continued to affirm convictions based on confessions obtained under dubious circumstances and the Supreme Court continued to reverse, knowing that for every case it reviewed, there were many more it could not. ${ }^{221}$ In the end, the voluntariness standard had proven to be too fact-driven to restrain police behavior or provide guidance to lower courts, particularly those inclined to protect defendants no more than they absolutely had to. If the Court was going to make a dent in the number of coerced confessions, it needed a more definitive rule.

The Supreme Court's first attempt at imposing a bright-line rule to curb coercive police interrogation came in the 1964 case of Escobedo v. Illinois. ${ }^{222}$ Again, the facts were ideally suited for doctrinal change. Danny Escobedo was twenty-two years old when Chicago police arrested him for murdering his brother-in-law and brought him in for questioning. ${ }^{223}$ During the interrogation, Escobedo repeatedly told the police he wanted to talk to his lawyer, who, as it turned out, was

${ }^{219}$ See LAFAVE ET AL., supra note 41, at 313-17 (discussing factors relevant to the voluntariness test).

${ }^{220}$ See 1961 CIVIL RIGHTS REPORT, supra note 140, at 28 ("Police brutality-the unnecessary use of violence to enforce the mores of segregation, to punish, and to coerce confessions-is a serious problem in the United States."); id. at 27 ("The statistics suggest that Negroes feel the brunt of official brutality proportionately more than any other group in American society."); see also Sitton, supra note 191, at 10 (noting law enforcement's use of fear and brutality in making arrests and obtaining evidence).

${ }^{221}$ Of the thirty-six coerced confession cases the Supreme Court heard from 1940 to 1964 , the Court reversed in twenty-six. BAKER, supra note 189 , at 74 . During oral arguments in Miranda, Justice Black candidly conceded that the Court was institutionally incapable of maintaining the case-by-case review that the voluntariness standard required:

If you are going to determine [the voluntariness of a confession] each time on the circumstances after a man has been arrested, this means that someone has just-that this Court will take them one-by-one, and no court in the land can ever know what violates that right not to be compelled to incriminate oneself, until it comes to us and we decide it. ... It is more than we are capable of doing.

Oral Argument, Miranda v. Arizona, 384 U.S. 436 (1966) (No. 759), reprinted in 63 LANDMARK BRIEFS, supra note 83, at 843, 894; see also Fred P. Graham, Court Ponders Where to Draw Line on Confessions, N.Y. TIMES, Mar. 6, 1966, at E6 ("Everybody knew that for every coerced confession the Supreme Court struck down, thousands passed unnoticed.").

${ }_{223}^{223} 378$ U.S. $478(1964)$.
Id. at 479. 
also at the police station trying to talk to him. ${ }^{224}$ Despite the existence of a state statute specifically providing persons in custody access to an attorney upon request, ${ }^{225}$ the police refused to allow the two to meet until after Escobedo had confessed. ${ }^{226}$ By that time, he had been handcuffed in a standing position for three hours and promised that he would only be used as a witness if he gave a statement implicating an alleged accomplice as the triggerman. ${ }^{227}$ Naturally, Escobedo was indicted for murder shortly thereafter and subsequently convicted of the charge. ${ }^{228}$

Though the Supreme Court could have easily reversed Escobedo's conviction under the voluntariness standard, ${ }^{229}$ it relied on the Sixth Amendment right to counsel to do so instead. The Court's holding in Escobedo was extremely limited, so much so that just stating it took an entire paragraph. ${ }^{230}$ The bottom line, however, was that the Sixth Amendment prohibited police who had "focused" on a suspect from denying that suspect's request to consult an attorney during custodial interrogation. ${ }^{231}$ In 1964, the proposition that arrestees who had lawyers should be able to see them upon request was not particularly startling; as one officer told the press, "[a]nybody would have known that

224 Id. at 480.

${ }^{225}$ See id. at $481 \mathrm{n} .2$ ("The statute then in effect provided ... that: "All public officers... having the custody of any person ... restrained of his liberty for any alleged cause whatever, shall, except in cases of imminent danger of escape, admit any practicing attorney... whom such person ... may desire to see or consult ...."' (quoting ILL. REV. STAT. ch. 38, $\$ 477$ (1959) (repealed 1963))).

Id. at $481-82$.

${ }^{227}$ Id. at 482 .

228 Id. at 483 .

${ }^{229}$ At conference, five Justices initially voted to do just that. THE SUPREME COURT IN CONFERENCE, supra note 86, at 513-14.

${ }^{230}$ The Court stated its holding as follows:

We hold, therefore, that where, as here, the investigation is no longer a general inquiry into an unsolved crime but has begun to focus on a particular suspect, the suspect has been taken into police custody, the police carry out a process of interrogations that lends itself to eliciting incriminating statements, the suspect has requested and been denied an opportunity to consult with his lawyer, and the police have not effectively warned him of his absolute constitutional right to remain silent, the accused has been denied "the Assistance of Counsel" in violation of the Sixth Amendment to the Constitution as "made obligatory upon the States by the Fourteenth Amendment," and that no statement elicited by the police during the interrogation may be used against him at a criminal trial.

Escobedo, 378 U.S. at 490-91 (citation omitted).

${ }^{231}$ Id. The Court later limited Escobedo's holding to its own facts. See Kirby v. Illinois, 406 U.S. 682, 689 (1972) (recognizing this limitation). 
guy had a right to see his attorney." ${ }^{232}$ Yet Escobedo's bark was worse than its bite. Nestled into the Court's opinion were sweeping condemnations of police interrogation and convictions based on a defendant's confession ${ }^{233}$-and the fact that the Court had moved the Sixth Amendment right to counsel from the courtroom to the "squealroom" had an ominous cast. At the time, it certainly looked as though the Supreme Court was about to give suspects subject to custodial interrogation Gideon's right to an attorney, and that would have effectively ended police-procured confessions altogether.

Not surprisingly, those in law enforcement sharply criticized the Court's decision in Escobedo, as did the conservatives who tended to back them. ${ }^{234}$ Among the general public, however, Escobedo was not salient enough to cause a reaction one way or the other. ${ }^{235}$ In 1966,

${ }^{232}$ Criminal Justice: Concern About Confessions, supra note 153, at 65; see also Joseph W. Bishop, Jr., The Warren Court Is Not Likely to Be Overruled, in THE SUPREME COURT UNDER EARL WARREN, supra note 29, at 93, 97 (describing Escobedo as laying down "the not-very-startling rule that a man who is being questioned by the police is entitled to a lawyer when he asks for one"); supra note 225 and accompanying text (noting an Illinois statute providing the same right recognized in Escobedo).

${ }^{233}$ See Escobedo, 378 U.S. at 488-89 ("We have learned the lesson of history ... that a system of criminal law enforcement which comes to depend on the 'confession' will, in the long run, be less reliable and more subject to abuses than a system which depends on extrinsic evidence independently secured through skillful investigation." (footnotes omitted)); id. at 490 ("This Court also has recognized that "history amply shows that confessions have often been extorted to save law enforcement officials the trouble and effort of obtaining valid and independent evidence ...."' (quoting Haynes $v$. Washington, 373 U.S. 503, 519 (1963))); id. ("If the exercise of constitutional rights will thwart the effectiveness of a system of law enforcement, then there is something very wrong with that system." (footnote omitted)).

${ }^{234}$ See Powe, supra note 12, at 391-92 (discussing the hostile reaction to Escobedo among police and conservatives and mentioning sharp criticism of the decision by former President Eisenhower and 1964 presidential candidate Barry Goldwater). It is somewhat puzzling why the law enforcement community was so upset with Escobedo when the Court's holding was relatively uncontroversial. The answer, I believe, lies in the press coverage of Escobedo, which relayed the decision's disturbing implications. See, e.g., Use of Confession in Trial is Curbed, N.Y. TIMES, June 23, 1964, at 1 (quoting Justice White's dissenting view that Court's ruling in Escobedo would cripple law enforcement).

${ }^{235}$ See Walter F. Murphy \& Joseph Tanenhaus, Public Opinion and Supreme Court: The Goldwater Campaign, 31 Pub. OPINION Q. 31, 35-36 (1968) ("The Supreme Court's decisions on reapportionment and on the rights of defendants in criminal cases, the two subjects that Goldwater assailed most frequently and stridently, were barely visible to the public at large."); id. at 46 ("Goldwater's complaints about the Court's decisions on reapportionment and the rights of criminal defendants could not possibly have had a great impact on public opinion. There was simply little popular reaction to these rulings."). Given law enforcement's low public esteem in 1964, there is no reason to assume that the views of police on Escobedo were representative of the public at large. 
when Escobedo's picture graced the cover of Time, that was no longer the case. ${ }^{236}$ At that time, however, the press was eagerly awaiting the Court's decision in Miranda, and its coverage of Escobedo was completely favorable. Indeed, Time's 1966 cover story portrayed Escobedo much like Gideon had been depicted three years earlier, describing him as "a nobody for everybody" and using his case to illustrate why further police restraints-like those being considered in Mirandawere both appropriate and necessary. ${ }^{237}$

Even so, the Supreme Court's approach in Escobedo was, like its voluntariness standard, inherently problematic. Lower courts generally construed Escobedo's holding in the same limited fashion in which it had been presented, recognizing a Sixth Amendment right to counsel during custodial interrogation only when defendants had hired lawyers and asked to see them. ${ }^{238}$ Because most defendants were too poor to hire their own attorney and too ignorant to know they could access one upon request, Escobedo had little practical effect. ${ }^{239}$ Meanwhile, the problem of coerced confessions began to receive substantial

See infra note 284 and accompanying text (discussing the negative public image of law enforcement officials in 1964).

${ }^{236}$ See Criminal Justice: Concern About Confessions, supra note 153 (reproducing Escobedo's booking photo on front cover).

${ }^{237}$ Id. at 53-58. Interestingly, Time described Escobedo as a man who, at 5'5" and 106 pounds, "hardly seem[ed] a threat to any healthy policewoman." Id. at 54,60. The article even went so far as to suggest that Escobedo may have been justified in killing his brother-in-law and that Chicago police had planted evidence on him after his murder charges were dropped so they could bring another charge. Id. at 54,58 . As time passed, however, it became clear that Escobedo was not the victim Time made him out to be. He was subsequently convicted of drug dealing, attempted murder, indecent liberties, and possession of illegal weapons; as of 2000, he was still serving time on the weapons charge. See POWE, supra note 12, at 411 (discussing Escobedo's subsequent charges and claim by a sentencing judge that Escobedo was a "career criminal").

${ }^{238}$ See P.A. Agabin, Annotation, Accused's Right to Assistance of Counsel at or Prior to Arraignment, 5 A.L.R.3D 1269, 1284 (1966) (noting a division of opinion among courts as to whether the defendant must request counsel, with most holding that a request is necessary). For a discussion of the various positions taken by the states after Escobedo but before Miranda, see generally Criminal Justice: Concern About Confessions, supra note 153 , at 57-58.

${ }^{239}$ As one New York Times article noted:

So few lawyers ever appear at the precinct house while a suspect is being questioned-and so few suspects are worldly enough to ask for a lawyer or well-off enough to afford one-that the effect on police procedures would be negligible if that was all the court meant when it reversed Escobedo's murder conviction.

Sidney E. Zion, In the Station House, N.Y. TIMES, Dec. 23, 1965, at 33; see also supra note 55 (describing the socioeconomic status of typical criminal defendants). 
publicity, ${ }^{240}$ prompting some law enforcement officials to admit publicly that the third degree was still in use. In New York, for example, a former deputy police commissioner confided:

"It is hardly news that suspects of serious crimes often get 'worked over' in the back rooms of station houses. The truth is that most crimes are not solved by fingerprints and wristwatch radios and the skillful assembling of clues. The suspect confesses, voluntarily or involuntarily." ${ }^{241}$

Clearly, the Supreme Court needed a better solution to the problem of coercive custodial interrogation, one that would protect the poor, unsophisticated defendants who were most susceptible to abusive police practices in the first place. With well over 100 certiorari petitions asking the Court to clarify Escobedo's reach by late $1965,{ }^{242}$ the time had come to try again.

${ }^{240}$ That publicity began around May 1965, in the wake of the George Whitmore case. In 1964, Whitmore confessed to murdering three women; his case was cited by a Manhattan prosecutor as "the perfect example of the importance of confessions in law enforcement" and an illustration of "how unrealistic and naive the Court [wa]s" in its Escobedo decision. Sidney E. Zion, The Suspect Confesses-But Who Believes Him?, N.Y. TIMES, May 16, 1965, $\$ 6$ (Magazine), at 30 . By early 1965 , the same prosecutor had to drop all charges against Whitmore (who claimed he only confessed because the police beat him) because the physical evidence in the case failed to match his confession, creating a "stink bomb" of adverse publicity. Id. at 30-31, 89-90. Whitmore's case was reportedly mentioned as much as Escobedo at a National District Attorney's Association meeting, id. at 90, and was salient enough to be mentioned in the Supreme Court's Miranda opinion as well. See Miranda v. Arizona, 384 U.S. 436, $455 \mathrm{n} .24$ (citing the Whitmore case as the "most recent conspicuous example" of coercive interrogation resulting in a false confession). March 1965's "Bloody Sunday" in Selma, Alabama, probably also contributed to the rise in adverse publicity for police in general and confessions in particular. See infra notes 281-82 (discussing Selma and its effect on public opinion of police). In any event, given the non-salient nature of the Court's 1964 decision in Escobedo, it is doubtful that the decision was in any way responsible for the public attention given to confessions in 1965. See supra note 235 and accompanying text (noting Escobedo's lack of public impact).

${ }^{241}$ The Revolution in Criminal Justice, TIME, July 16, 1965, at 22, 22 (quoting former New York City Deputy Police Commissioner Richard Dougherty); see also Eric Pace, Confession Role Asked for Judges, N.Y. TIMES, Dec. 23, 1965, at 33 (quoting the chairman of the penal law committee of the New York State Bar Association as saying, "I'm not a cop fighter. If you'll pardon the expression, some of my best friends are cops, [but] I know what goes on in a police station").

${ }^{242}$ See CRAY, supra note 59, at 457 ("By November, 1965, Earl Warren's clerks had identified 170 appeals from state prisoners who raised the unanswered issues of the previous year's Escobedo decision ...."). 


\section{B. Miranda's Holding and Historical Context}

When the Supreme Court granted certiorari in Miranda v. Arizona ${ }^{243}$ and a few other "Escobedo cases" in November $1965,{ }^{244}$ it was obvious that the Court was going to lay down another bright-line rule for regulating custodial interrogation; the only question was what that rule would be. Because the Court had been on the verge of extending the full Sixth Amendment right to counsel to custodial interrogation in Escobedo, many feared it would actually take that step in Miranda, effectively eliminating law enforcement's ability to obtain even so-called "voluntary" confessions. ${ }^{245}$ Others doubted that the Court would go that far, predicting instead that it would simply require warnings prior to custodial interrogation. ${ }^{246}$ Importantly, a warnings requirement was the least the Supreme Court could do to place unsophisticated defendants on equal footing with their more knowledgeable counterparts, rectifying at least part of the problem with Escobedo's limited holding. ${ }^{24}$

As we all know, the Supreme Court in Miranda chose the latter option, interpreting the Fifth Amendment to require four warnings that are now so famous, anyone who watches television can recite them. ${ }^{248}$ That was a significant step back from where the Court appeared to be

${ }^{243} 384$ U.S. 436 (1966).

${ }^{244}$ Miranda was a consolidated case involving four appeals: Miranda v. Arizona, 384 U.S. 436, 491-93 (1966), Vignera v. New York, 384 U.S. 436, 493-95 (1966), Westover v. United States, 384 U.S. 436, 494-97 (1966), and California v. Stewart, 384 U.S. 436, 497-99 (1966).

${ }^{245}$ See Kamisar, supra note 59 , at 120 (discussing the fear of prominent judges, law enforcement officials, and other members of the bar that the Supreme Court in Miranda would condition interrogation on the presence of counsel).

${ }^{246}$ See, e.g., Criminal Justice: Concern About Confessions, supra note 153, at 58 ("So far, the best guess of Washington lawyers is that the court may simply require police to warn prime suspects of their rights....").

${ }^{247}$ The other problem was that even among defendants who knew they could have access to an attorney upon request, many were too poor to afford one. See supra note 239 and accompanying text (noting the poverty of most criminal defendants). Miranda addressed this problem as well by requiring the state to provide courtappointed counsel to indigent felony defendants upon request. See infra note 248 (quoting the required warnings).

248 Miranda held:

[A defendant] must be warned prior to any questioning that he has the right to remain silent, that anything he says can be used against him in a court of law, that he has the right to the presence of an attorney, and that if he cannot afford an attorney one will be appointed for him prior to any questioning if he so desires.

384 U.S. at 479. 
heading in 1964, though only upon closer inspection can one appreciate just how much of a step back Miranda's ruling truly was. According to the Court in Miranda, the central problem with police interrogation was the inherently coercive atmosphere in which it took place. ${ }^{249}$ Indeed, the Court went to great lengths to document the tactics police used to discourage suspects from enlisting an attorney's aid or exercising their right to silence. ${ }^{250}$ In light of that fact, it is somewhat surprising that Miranda sanctioned police-provided warnings in lieu of requiring that they be given by a neutral and detached magistrate, as several prominent jurists suggested while the case was pending. ${ }^{251}$ Equally surprising is the fact that Miranda failed to require that the warnings be recorded, as others were then advocating, so that courts could at least monitor what, if anything, the police were doing to convince defendants to waive their rights. ${ }^{252}$ Given these considerations, it is little wonder that Justice Fortas described Miranda as a "conservative decision" just after it was issued; ${ }^{253}$ the Court's ruling did nothing whatsoever to prevent the coercion police used to make suspects talk from translating to the waiver context.

249

See id. at 445-57 (detailing the coercive conditions of custodial interrogation); see also id. at 467 (concluding that "the process of in-custody interrogation of persons suspected or accused of crime contains inherently compelling pressures which work to undermine the individual's will to resist and to compel him to speak where he would not otherwise do so freely").

${ }^{250}$ See id. at 454 (quoting interrogation instructions from FRED E. INBAU \& JOHN E. REID, CRIMINAL INTERROGATION AND CONFESSIONS 111-112 (1962)).

${ }^{251}$ See, e.g., David L. Bazelon, Letter to the Editor, Rights of Suspects, N.Y. TIMES, Dec. 20,1965, at 34 ("My view is that we cannot expect the police to advise a suspect effectively and disinterestedly of his right to remain silent at the same time as they are trying to elicit a confession from him."); Pace, supra note 241, at 33 (reporting a New York State Supreme Court justice's opinion that police were unsuited to inform suspects of their rights and advocating that a neutral magistrate do so instead); see also Sidney E. Zion, Justice Scorns Confession as Key to Enforcement, N.Y. TimES, Nov. 20, 1965, at 1 ("Libertarians have long argued that a police station is coercive in itself and that a lawyer, rather than a detective, should advise a suspect of his rights.").

${ }^{252}$ See infra note 260 and accompanying text (discussing provisions of American Law Institute's proposed prearraignment procedures that would require police to make audio-recordings of both warnings and any subsequent waiver of rights); see also Sidney E. Zion, Ryan Asks Wide Revisions in Police Interrogation, N.Y. TIMES, Sept. 2, 1965, at 37 (reporting a New York City representative's call for "closed-circuit televising of the questioning of suspects").

${ }^{253}$ At that time, Justice Fortas also predicted that many suspects would waive their rights. See GRAHAM, supra note 41 , at 182 (quoting a conversation with Justice Fortas a few months after Miranda was issued). Given the experience of police departments that provided pre-interrogation warnings to suspects prior to Miranda, Justice Fortas's prediction was well-founded. See infra note 298 and accompanying text (discussing the ability of police to obtain confessions despite having warned suspects of their rights). 
Of course, even if Miranda was a comparatively weak decision in light of Escobedo and the Court's concerns about custodial interrogation, it still could have been wildly countermajoritarian. It is difficult to conclude that this was the case, however, given the sociopolitical context in which Miranda was decided. Admittedly, only three states-California, Oregon, and Rhode Island-mandated Mirandalike warnings in 1966, and all three did so only because they interpreted Escobedo to implicitly require them. ${ }^{254}$ Yet the Court's holding in Miranda did not spring out of thin air. By the time Miranda was decided, a number of legal reform bodies had been studying the problem of coercive police interrogation for years, with the prestigious American Law Institute (ALI) leading the pack. ${ }^{255}$ By late 1965, both the American Bar Association and the National Crime Commission had agreed to endorse the ALI's Model Code of Pre-Arraignment Procedures, ${ }^{256}$ which was thought to represent the views of the nation's most influential law enforcement and conservative legal figures. ${ }^{257}$ Given the Model Code's endorsements, it is hardly a stretch to

${ }^{254}$ See, e.g., People v. Dorado, 398 P.2d 361, 371 (Cal. 1965) (holding that defendant's confession was inadmissible because the police had focused on the defendant as a "particular suspect" and subjected him to custodial interrogation without adequately informing him of his right to counsel and right to remain silent); State v. Neely, 398 P.2d 482, 486-87 (Or. 1965) (holding that "before law enforcement officials can interrogate a person who is the focal suspect of a crime, such person must effectively be informed of his right to assistance of counsel as well as his right to remain silent"); State v. Dufour, 206 A.2d 82, 85 (R.I. 1965) (citing Escobedo in holding that a court must "consider the validity of the confession in the light of its having been obtained without the police previously advising defendant of his right to have assistance of counsel").

${ }^{255}$ The three main reform bodies involved in that endeavor were the American Law Institute (ALI), the American Bar Association's Special Committee on Minimum Standards for the Administration of Criminal Justice, and the President's Commission on Law Enforcement and Administration of Justice (commonly known as the National Crime Commission). See GRAHAM, supra note 41, at 174-75 (describing the collaboration of these groups on the creation of the Model Code as "a more-than-coincidental concert of views on police interrogation ... between the most powerful nonjudicial legal institutions in the United States"). The ALI was the first of these groups to study the problem of coercive interrogation, having received a Ford Foundation grant to do so in April 1963. See BAKER, supra note 189, at 16 (discussing the purpose and scope of the Ford Foundation grant). The American Bar Association undertook a similar project in February 1964, months before Escobedo was decided. See Austin C. Wehrwein, Bar Will Survey Criminal Justice, N.Y. TIMES, Feb. 14, 1964, at 9 (announcing the ABA's criminal justice project). Thus, the Court's decision in Escobedo cannot even be credited for galvanizing other reform groups into action.

${ }^{256}$ MOdel Code of Pre-ARRAignment Procedure (Tentative Draft No. 1, 1966).

${ }^{257}$ See BAKER, supra note 189, at 159 (discussing membership of the Model Code's Advisory Committee); GRAHAM, supra note 41, at 174-75 (noting that the ABA and National Crime Commission both supported the ALI's proposed Model Code). 
conclude, as others have, that the ALI's project "carr[ied] the political and scholarly weight of virtually the entire American legal establishment." ${ }^{258}$

For the purpose of this analysis, the substance of the ALI's draft Model Code-published just days after the Supreme Court heard oral arguments in Miranda $a^{259}$-is most revealing. On the subject of custodial interrogation, the draft Model Code proposed that police be required to warn suspects of their right to silence and right to consult an attorney, audio-recording both the warnings and any subsequent waiver. ${ }^{260}$ The draft Model Code also provided for a maximum fourhour interrogation period without an attorney's presence or consent, so that even arrestees who had waived their right to counsel would find their waiver invalid after a certain period of time. ${ }^{261}$ Concededly, the ALI's draft proposal differed from Miranda's holding in that it did not require the police to advise suspects of their right to courtappointed counsel; in the draft Model Code, this right did not exist. Yet, even within the ALI, many thought indigent defendants should have a right to court-appointed counsel during custodial interrogation, creating a rift that was at least partly responsible for the draft Model Code's failure to make it to final form. ${ }^{262}$ In any event, with one notable exception (and the significance of that exception is

${ }^{258}$ BAKER, supra note 189 , at 159; see also GRAHAM, supra note 41, at 175 (noting that "[I]f the ALI were to approve its plan before the Supreme Court made its confessions decision, the slim Warren majority could find itself declaring a new constitutional right that the nation's legal establishment had only recently rejected").

${ }^{259}$ Miranda was argued from February 28 to March 2, 1966, and the ALI's draft Model Code was published on March 1. BAKER, supra note 189, at 159. Chief Justice Warren attended the ALI's annual conference in May 1966, where the proposed code was debated. Id. at 160 .

${ }^{260}$ MOdel Code of PRE-ARraignment Procedure $\$ \S 4.01,4.09$ (Tentative Draft No. 1, 1966).

${ }^{261}$ Id. $\$ \S 4.04,5.08$.

262 See BAKER, supra note 189, at 160-61 (noting that the Model Code was not brought to a vote in part because of disagreement as to its provisions); see also Editorial, Limits on Confessions, N.Y. TIMES, Mar. 7, 1966, at 26 (criticizing the ALI's draft Model Code for making the safeguards a defendant enjoys "a matter of purse"); Sidney E. Zion, Model Crime Code Scored by A.C.L.U., N.Y. TIMES, May 17, 1966, at 1 (reporting that the ALI's proposed Model Code had already been "hotly condemned by a number of leading legal experts" including Chief Judge David L. Bazelon of the D.C. Court of Appeals, who criticized its failure to provide an attorney for indigent defendants as discriminating against the poor). Admittedly, the main reason no vote was taken at the ALI conference in May was the fact that Miranda was pending, and some ALI members considered it a matter of professional courtesy to await the Court's ruling before taking further action. BAKER, supra note 189 , at 160-61. 
debatable), ${ }^{263}$ the ALI's proposed prearraignment procedures afforded the same, and in some aspects more, protection to suspects during custodial interrogation than Miranda-not bad for a project thought to represent the views of conservatives and the police.

Elsewhere, too, were significant indications that the Supreme Court's holding in Miranda was well within the parameters of publicly acceptable responses to the problem of coercive interrogation. By the time Miranda was decided, the FBI had been issuing the exact same warnings for years; indeed, its practice in that regard was described by one justice as "'a tremendously important factor, perhaps the critical factor in the Miranda vote." "264 Yet the FBI was not the only law enforcement body to issue warnings before Miranda. Across the country, police departments in a number of metropolitan areas-including Denver, Detroit, Minneapolis, and Philadelphia-had also begun warning suspects of their rights well before the Supreme Court forced them to do $\mathrm{so}^{265}$ in part because state courts had themselves become increasingly interested in warnings when determining the voluntariness of a confession. ${ }^{266}$ News articles written while Miranda

263 See infra notes 317-19 and accompanying text (arguing that the Supreme Court in Miranda never envisioned the police actually providing indigent defendants with counsel).

${ }^{264}$ See CRAY, supra note 59, at 458 (quoting an unnamed Justice). The Court's Miranda opinion relied heavily on this fact. See Miranda v. Arizona, 384 U.S. 436, 483-86 (1966) (using the FBI's "present pattern of warnings and respect for the rights of the individual" as support for requiring "state and local agencies" to adopt similar procedures).

${ }^{265}$ See Criminal Justice: Concern About Confessions, supra note 153, at 65 (describing the use of warnings by police in Denver, Miami Beach, Detroit, Philadelphia, and Seattle); Fred P. Graham, General Reaction is Mild-Crime Unit Aide Sees No Major Changes, N.Y. TImES, June 15, 1966, at 1 (noting that police in Oklahoma City, Minneapolis, Albuquerque, Denver, and Sacramento said their practices already followed the new guidelines); see also Zion, supra note 251, at 70 (reporting that at least two Eastern prosecutors had voluntarily ordered police to warn suspects of their rights prior to interrogation).

${ }_{266}$ As Professor LaFave noted in 1962:

If any trend at all is to be discerned in the state confession cases, it would be increased concern over lack of warning and denial of counsel. ... [M]ore and more courts have indicated by dicta a possible willingness to strike down any statement received when a suspect was not warned or when he was not allowed to contact counsel.

Wayne R. LaFave, Detention for Investigation by the Police: An Analysis of Current Practices, 1962 WASH. U. L.Q. 331, 388 (footnotes omitted). The Supreme Court's confession cases under the voluntariness standard had likewise come to consider warnings as an important factor in determining whether a defendant's confession was admissible. See, e.g., Haynes v. Washington, 373 U.S. 503, 517 (1963) (recognizing warnings as an appropriate circumstance to be considered in voluntariness inquiry). Likewise, Escobedo's 
was pending likewise supported the Court's forthcoming ruling, portraying warnings as an almost muted response to the enormous problem that abusive police interrogation had become. ${ }^{267}$ Indeed, by early 1966 , the idea of warning suspects of their rights before custodial interrogation had become so publicly acceptable that in New York, a bill requiring preinterrogation warnings passed in the legislative assembly by a vote of 100 to $31^{268}$ — with the strong endorsement of the Brooklyn and Manhattan district attorneys. ${ }^{269}$ Given these historical facts, it is difficult to conclude that Miranda was anything other than a reflection of what criminal justice reformers were championing at the time.

Just the same, the Supreme Court's decision in Miranda makes all the more sense when considered in light of the prevailing social and political movements of its time. By 1966, when Miranda was decided, the nation had committed itself to a war on poverty. ${ }^{270}$ Even the government's brief in Miranda candidly conceded that it was virtually impossible to pick up a paper or listen to a public address without being reminded of the country's concern for its downtrodden and poor. ${ }^{271}$

narrowly tailored holding relied, in part, on the fact that the police had not warned the defendant of his right to silence. See Escobedo v. Illinois, 378 U.S. 478, 491-92 (1964) (noting lack of warnings among facts relevant to narrow holding).

${ }^{267}$ See, e.g., Criminal Justice: Concern About Confessions, supra note 153, at 58 (noting that the presence of lawyers would bolster public faith in police interrogation but predicting that the Supreme Court "may simply require police to warn prime suspects of their rights" instead); Graham, supra note 221, at E6 (concluding that the only way to solve the problem of coerced confessions is to prohibit interrogation outside of an attorney's presence, but predicting that the Supreme Court instead will take "another measured step" toward that rule by requiring warnings first and then waiting a while before proceeding).

${ }^{268}$ Sydney H. Schanberg, Assembly Backs Suspects' Rights, N.Y. TIMES, May 24, 1966 , at 35 (reporting passage of bill and its contents).

${ }^{269}$ See Sidney E. Zion, Access to Lawyer Is Urged By Koota, N.Y. Times, Nov. 22, 1965, at 39 (reporting position of Brooklyn district attorney that confessions should not be admissible absent evidence that suspects understood they could have a lawyer, including a court-appointed one); Zion, supra note 252, at 37 (noting that both the Manhattan District Attorney and the Democratic candidate for Mayor of New York recommended that police warn suspects of their rights to silence and counsel before interrogation).

${ }^{270}$ See supra note 197 and accompanying text (discussing President Johnson's declaration of the war on poverty in 1964).

${ }^{271}$ The brief stated:

$[P]$ oor, motherless, unloved, downtrodden, culturally deprived, misguided, unguided, harassed, ad infinitum. It is practically impossible to pick up a national magazine, professional journal, or listen to an address without some dramatic usage of these descriptive adjectives to characterize some greater or lesser portion of the American population. 
That being the case, we should hardly be surprised to see the Court in Miranda take steps to protect indigent suspects subject to custodial interrogation; those steps mirrored perfectly the economic egalitarianism of the mid-1960s that marked the national mood. After all, the rich had Escobedo. It was the poor who needed Miranda, just as they had needed Gideon three years before. ${ }^{272}$ And no matter what people thought about greater protections for accused criminals generally, no one in 1966 was willing to argue that rich criminal defendants deserved more protection than their poor counterparts. ${ }^{273}$

Naturally, the civil rights movement also played a role in Miranda's outcome, though perhaps not in the way casual observers might suppose. By 1966, the nation had already been convinced of the need for racial equality; that much was clear from the 1964 Civil Rights Act ${ }^{274}$ and 1965 Voting Rights Act. ${ }^{275}$ One would think this national consensus on racial equality would have made the Supreme Court even more solicitous of minority rights in the criminal procedure context than it had been in years past, and, in part, that was true. According to an early draft of the Miranda opinion, the majority initially saw the case as an opportunity to protect black defendants, rather than poor ones. ${ }^{276}$ Yet the civil rights movement did something else that affected the Supreme Court's attitude toward police interrogation as well-

Brief for Respondent at 10, Miranda v. Arizona, 384 U.S. 436 (1966) (No. 759), reprinted in 63 LANDMARK BRIEFS, supra note 83, at 674, 683.

${ }^{272}$ See, e.g., The Revolution in Criminal Justice, supra note 241, at 22 (contending that interrogation is not a problem "for the big-time crook with an attorney," just the suspect without a lawyer-and that $60 \%$ of criminal suspects cannot afford one).

${ }^{273}$ See, e.g., Sidney E. Zion, Koota Says New Court Rulings Have 'Shackled' Police Officials: A Detective's View, N.Y. TIMES, Aug. 13, 1966, at 1 (quoting New York City commander of detectives as saying, "[I]n some ways I favor the decision [in Miranda], because at least it gives the poor, unfortunate suspect, the guy you have to protect, the same rights as the hardened criminal, who has the money for a lawyer and would never talk anyway").

${ }^{274}$ Civil Rights Act of 1964, Pub. L. No. 88-352, 78 Stat. 241 (codified as amended in scattered sections of 42 U.S.C.) (establishing uniform standards for the right to vote).

${ }^{275}$ Voting Rights Act of 1965, Pub. L. No. 89-110, 79 Stat. 437 (codified as amended at 42 U.S.C. $\$ \S 1971,1973$ to $1973 \mathrm{bb}-1$ (2000)) (removing the right of states to impose voting qualification restrictions).

${ }^{2 / 6}$ See CRAY, supra note 59, at 459 (discussing and quoting an early Miranda draft that couched the problem of coercive interrogation in terms of brutality against black defendants). It was Justice Brennan who suggested that the Court's Miranda opinion shift its focus. See id. (noting Justice Brennan's position that poverty, rather than race, better characterized the victims of police brutality). 
it created a "crisis of confidence" in the country's law enforcement establishment. ${ }^{277}$

Most likely, the seeds of that crisis were planted in May of 1963, when the entire nation watched Birmingham's Commissioner of Public Safety, Bull Connor, unleash his police department on over one thousand schoolchildren who were peacefully protesting the city's segregationist practices. Now-legendary pictures of white policemen using dogs, clubs, and firehoses to brutally suppress black children shocked the nation's conscience and, for the first time, forced it to confront the fact that police power was being used for illegitimate purposes. ${ }^{278}$ In 1964, national attention again focused on lawless police practices when an FBI investigation dubbed "Mississippi Burning" resulted in federal conspiracy charges against a local Mississippi sheriff and his deputies for the murder of three civil rights workers. ${ }^{279}$ And if that was not enough, March 1965 witnessed "Bloody Sunday" in Selma, Alabama. Selma was the starting point of a fifty-four-mile protest march for voting rights that would have ended in the state capital

${ }^{277}$ Zion, supra note 252, at 37 (quoting Representative William F. Ryan, Democratic candidate for Mayor of New York City).

${ }^{278}$ See MATUSOW, supra note 133, at 87 ("Connor... set upon the marchers with dogs, clubs, and firehoses, making martyrs of his victims and assuring their triumph."); POWE, supra note 12, at 224-25 (discussing Birmingham's importance to the civil rights movement); WILliAMS, supra note 131, at 190-92 (same). By all accounts, Birmingham created an immediate mass constituency for the civil rights movement and meaningful civil rights legislation. See Klarman, supra note 130, at 130-49 (linking Birmingham and other violent civil rights confrontations of the early- to mid-1960s with the civil rights legislation that followed); see also Alexander M. Bickel, Politics ANd THE WARREN COURT 94 (1965) (noting that Birmingham was not the first time police had used power to suppress blacks, but it was "one of those events which seem[ed] to turn the course of history").

${ }^{279}$ See, e.g., James Atwater, If We Can Crack Mississippi, SATURday EvENING POST, July 25, 1964, at 15, 15-16 (describing the search for three murdered civil rights workers); M.S. Handler, Author Describes Slaying of 3 Rights Workers in Mississippi, N.Y. TIMES, Oct. 26, 1964, at 20 (describing Louis Lomax's account of the murders of the civil rights workers); John Herbers, 5 Mississippians Arrested by F.B.I. on Rights Charge, N.Y. TiMES, Oct. 4, 1964, at 1 (reporting the arrest of Mississippi law enforcement officers on federal civil rights charges for the death of the civil rights workers); David Nevin, $A$ Strange, Tight Little Town, Loath to Admit Complicity, LiFE, Dec. 18, 1964, at 38, 38 (discussing the return to work of accused murderers Sheriff Lawrence Rainey and Deputy Cecil Price after dismissal of their federal indictments); Richard Woodley, A Recollection of Michael Schwerner, REPORTER, July 16, 1964, at 23, 23-24 (documenting the events preceding the disappearance and death of the three civil rights workers). A number of books on the event soon followed, see, e.g., WILLIAM BRADFORD HUIE, THREE LIVES FOR MISSISSIPPI (1965); WILlIAM MCCORD, MISSISSIPPI: THE LONG HOT SUMMER (1965); JACK MENDELSOHN, THE MARTYRS (1966), and eventually the incident became the subject of a major motion picture, MISSISSIPPI BURNING (Orion Pictures 1988). 
of Montgomery. ${ }^{280}$ Just outside of town, however, state troopers descended upon the marchers with tear gas and billy clubs, while a mounted posse of officers led by local Sheriff Jim Clark assaulted them with bullwhips and rubber hoses covered with barbed wire. ${ }^{281}$ All three major television networks broadcasted the carnage, appalling the nation and creating a massive constituency for voting rights legislation almost overnight. ${ }^{282}$ Understandably, then, when Americans of the mid-1960s pictured racism and minority oppression, the face they saw was that of a white policeman. ${ }^{283}$

Fair or not, the brutality and lawlessness exhibited by Southern police in response to the civil rights movement had a devastating effect on the public's perception of law enforcement as a whole. As early as 1964, Northern police complained about their "distorted and smeared" public image, portraying themselves as victims of misdirected frustration with a few Southern racist regimes. ${ }^{284}$ By early 1966 , a police spokesman was quoted in the New York Times as saying:

"Never before in the 150-year history of law enforcement has the police 'stock' been at a lower point. Never before have the police been under such constant-and largely undeserved-criticism. Never before have public expressions of confidence in police been so meager." 285

${ }^{280}$ See MATUSOW, supra note 133, at 182 (describing the planned protest march from Selma to Montgomery); POWE, supra note 12, at 258 (same).

${ }^{281}$ See MATUSOW, supra note 133, at 183 (detailing the events of "Bloody Sunday" in Selma, Alabama); POWE, supra note 12, at 258 (same); WILLIAMS, supra note 131, at 269,273 (same).

${ }^{282}$ See MATUSOW, supra note 133, at 183 ("Bloody Sunday, filmed for the evening news, appalled the North and created an instant constituency for a new voting law."); POWE, supra note 12, at 258-59 (noting that President's Johnson's biographer, Robert Dallek, stated that "'the national reaction to what the press called 'Bloody Sunday' was everything advocates of a voting rights law could have wished. Television provided graphic descriptions of the police actions, and newspapers all over the country featured the story on their front pages." (quoting ROBERT DALLEK, FLAWED GIANT 198-99 (1998))); WILLLAMS, supra note 131, at 273 (quoting Selma Mayor Joe Smitherman as stating that "it looked like war.... [a]nd the people, the wrath of the nation came down on us'"). For an excellent exposition of Selma and its political ramifications, see David J. GarRow, Protest at Selma (1978).

${ }^{283}$ See WALKER, supra note 108, at 222 (discussing Birmingham and noting that "[t]he police became the symbol of an unjust society").

${ }^{284}$ Emanuel Permutter, Murphy Assails Critics of Police, N.Y. TIMEs, Aug. 23, 1964, at 48; see also Margaret Mead, Letter to the Editor, Urban Violence Discussed, N.Y. TIMES, June 23, 1964, at 32 (noting the perception of police "as the natural enemies of lawabiding citizens and lawbreakers alike").

Support for Police Seen at Low Point, N.Y. TIMES, Feb. 4, 1966, at 38; see also Herbert Packer, The Courts, the Police, and the Rest of Us, 57 J. CRIM. L. \& CRIMINOLOGY 238, 
The problem, the spokesman went on to explain, was that police were "'automatically equated with the "red-necked sheriff,","286 and he was right. What most people knew about police came from the likes of Bull Connor and Jim Clark-and that was a public relations nightmare. ${ }^{287}$

By 1966, when the Supreme Court decided Miranda, the public's distrust of law enforcement was manifest. Much to the law enforcement community's chagrin, major metropolitan areas throughout the country had established civilian review boards to hear complaints of police brutality, ${ }^{28}$ and the U.S. Commission on Civil Rights had recommended to Congress and the President that local governments be made liable to victims of police misconduct. ${ }^{289}$ The Supreme Court was not oblivious to these developments. Indeed, its own docket made ignoring police brutality virtually impossible. In November 1965, just two weeks before it granted certiorari in Miranda, the Court heard oral arguments in the Mississippi Burning case. In March 1966, the same month Miranda was argued, the Court unanimously reversed the lower court's dismissal of charges against law enforcement coconspirators in that case. ${ }^{290}$ With police brutality and lawlessness on everyone's mind-including the Justices'-it is hardly surprising that the Court acted to curb coercive police interrogation when it did. Distrust of law enforcement had prompted the press to attack police

241 (1966) ("It is widely recognized that community relations is a major problem facing the police today.").

${ }^{286}$ Support for Police Seen at Low Point, supra note 285, at 38.

${ }^{287}$ See Trigger of Hate, TIME, Aug. 20, 1965, at 13, 13 (reporting a judge's comment that "[w]hat [people] know about sheriffs and police is Bull Connor and Jim Clark .... The people distrust the police and the police distrust the people").

${ }^{288}$ See Thomas R. Brooks, Necessary Force-or Police Brutality?, N.Y. TIMES, Dec. 5 , $1965, \S 6$ (Magazine), at 60,68 (noting the use of civilian review boards in thirty-seven police departments across the nation to hear charges of police misbehavior); Police Chiefs' Head Urging Resistance to Review Boards, N.Y. Times, Oct. 29, 1964, at 27 (reporting speech by the President of the International Association of Chiefs of Police urging precincts to resist demands for civilian review boards and noting the existence of such boards in New York City, Philadelphia, and Rochester); see also Police-Review Units Deplored by Hoover, N.Y. TIMES, Dec. 31, 1964, at 42 (reporting FBI Director J. Edgar Hoover's criticism of civilian review boards then being championed in some localities).

${ }^{289}$ See John Herbers, Rights Board Asks Quick U.S. Arrests in Race Offenses, N.Y. Times, Nov. 14, 1965, at 1 (discussing the U.S. Civil Rights Commission's recommendations).

See United States v. Price, 383 U.S. 787, 794 (1966) (construing 18 U.S.C. $\$ 242$ to include murderous conduct by civilians acting in conformity with the sheriff, deputy sheriff, and patrolmen involved in that case). Price was argued on November 9, 1965. Id. Certiorari was granted in Miranda on November 22, 1965. Miranda v. Arizona, 382 U.S. 925 (1965). 
interrogation for a good year before Miranda was decided. ${ }^{291}$ It is hard to imagine that the Court would not eventually make the connection too.

Granted, there was another aspect of Miranda's historical context that seemingly cut against the Court's holding, and that was the nation's growing concern over crime. In 1966, the crime rate rose $10 \%$ over the previous year, a figure ten times higher than the country's $1 \%$ rate of population growth. ${ }^{292}$ That year, President Johnson even issued a special message to Congress on the subject, accompanied by legislative proposals and appropriations requests. ${ }^{293}$ To be sure, crime was becoming a major domestic issue when Miranda was decided, but it was not as salient as one might think. Gallup Poll results revealed that no one was listing crime among the country's most important problems in 1966; that year, the public was fixated on Vietnam, civil rights, and inflation instead. ${ }^{294}$ Perhaps the best explanation for the public's failure to focus on crime is the fact that in 1966 , a $10 \%$ rise in

291 See, e.g., Brooks, supra note 288, at 60 (relaying the account of a young man who died as the result of excessive force by a police officer and the lack of action subsequently taken against the officer); Graham, supra note 221, at E6 (noting the arguments for and against an automatic bar to confessions from police interrogation); Zion, supra note 269, at 39 (reporting the Brooklyn District Attorney's position that all people should have access to a lawyer "'at the moment [they come] into contact with the law" to guard against improperly solicited confessions); Zion, supra note 239, at 33 (discussing the merits of extending Fifth and Sixth Amendment protections to custodial interrogation); Zion, supra note 251, at 1 (reporting the view of a state trial court judge that confessions are not the "backbone" of criminal justice, as some in law enforcement claim); Zion, supra note 252, at 37 (reporting on suggestions made to change police interrogation methods); Zion, supra note 240 , at 30 (discussing the case of a false confession to a rape and two homicides); Limits on Confessions, supra note 262, at 26 (discussing the need for procedural safeguards on obtaining confessions); The Revolution in Criminal Justice, supra note 241, at 22 (describing the impact of heavyhanded police interrogation practices and their disproportionate effect on indigent defendants).

${ }^{292}$ See Fed. Bureau of InVESTIGation, U.S. DeP'T OF JUSTICE, UNiform CRIME REPORTS FOR THE UNITED STATES-1966, at 4 (1967) (reporting that population rose $1.1 \%$, while the crime rate from 1965 to 1966 rose $10 \%)$.

${ }^{299}$ See PowE, supra note 12, at 399 (describing crime as an important domestic issue in 1966 and noting President Johnson's special message to Congress on the subject).

${ }^{294}$ On May 27, 1966, Gallup asked the public what it considered to be "the most important problem facing the country today." 3 GEORGE H. GALLUP, THE GalluP POLL: PUBLIC OPINION 1935-1971, at 2009 (1972). The top three answers to that question were Vietnam (45\%), the high cost of living (16\%), and civil rights $(9 \%)$. Of the seven remaining answers, crime was not separately listed. Id. On September 11, 1966, and October 19, 1966, Gallup asked the same question, with similar results. See id. at 2026, 2034 (reporting that the Vietnam conflict, civil rights, and inflation were the three most important problems mentioned by survey respondents). 
the crime rate was nothing new. For the previous five years, the crime rate had risen from $5 \%$ to $11 \%$ per year, and 1966 was no different in that regard. ${ }^{295}$ This is not to deny that the crime problem was starting to grab the nation's attention when Miranda was decided. It was, but it was not the concern that civil rights and police brutality were, nor was it the concern it would become in 1967 and 1968, when crime rates did soar and the nation took note of it. ${ }^{296}$

Even so, the Supreme Court's decision in Miranda was almost uncanny in the way it dovetailed with the nation's emerging crimecontrol concerns. As already noted, Miranda's holding was a step back from the direction Escobedo had pointed in $1964,{ }^{297}$ a move that makes sense with crime starting to garner public attention. What has not yet been noted is that the Court knew warnings would not hinder police investigative activities one whit. While Miranda was pending, precincts across the country reported that warnings had no effect whatsoever on the ability of police to obtain confessions, a discovery given ample press coverage and buttressed by the FBI's experience. ${ }^{208}$ Equally significant is the fact that the Supreme Court refused to apply Miranda retroactively, an "unprecedented limitation" in its criminal procedure jurisprudence that prevented defendants in the exact same position as

295 See Fed. Bureau of INVESTIGATION, U.S. DEP'T OF JUSTICE, UNIFORM CRIME REPORTS FOR THE UNITED STATES-1962, at 3 (1963) (reporting 1962's 5\% rise in the crime rate); FED. BUREAU OF INVESTIGATION, U.S. DEP'T OF JUSTICE, UNIFORM CRIME REPORTS FOR THE UNITED STATES-1963, at 3 (1964) (reporting 1963's 9\% rise in the crime rate); FED. BUREAU OF INVESTIGATION, U.S. DEP'T OF JUSTICE, UNIFORM CRIME REPORTS FOR THE UNITED STATES-1964, at 3 (1965) (reporting 1964's 11\% rise in the crime rate); FED. BUREAU OF INVESTIGATION, U.S. DEP'T OF JUSTICE, UNIFORM CRIME REPORTS FOR THE UNITED STATES-1965, at 3 (1966) (reporting 1965's 5\% rise in the crime rate).

${ }^{296}$ See infra note 336 and accompanying text (discussing 1967's rise in crime rate compared to 1966); infra note 424 and accompanying text (discussing 1968's rise in crime rate compared to 1967 ).

297 See supra text accompanying notes 245-53 (discussing Miranda's holding against the backdrop of the Escobedo decision).

${ }^{298}$ See Criminal Justice: Concerm About Confessions, supra note 153, at 65 ("For police, at least, perhaps the most interesting news is that warnings by no means stop confessions."); Zion, supra note 239, at 3 ("Thus, although the police have contended that a suspect will refuse to talk if they must tell him he has the right to remain silent and to have a lawyer, there is important evidence that this is not necessarily so."); Zion, supra note 251 , at 70 (quoting a prosecutor who ordered police in his jurisdiction to warn suspects as saying, "I hate to admit it, but on the basis of our early reports, we haven't lost a single confession except to racket men and hardened criminals who never talk anyway."'); see also Miranda v. Arizona, 384 U.S. 436, 483 (1966) (noting the FBI's use of warnings without a loss in law enforcement effectiveness). 
Ernesto Miranda from benefiting from the Court's ruling. ${ }^{299}$ Even the facts of Miranda and its companion cases reveal the Court's keen awareness of the debate over confessions then raging in the legal community. Although the police conduct in Miranda was, as others have noted, as benign as it had been egregious in prior confession cases, ${ }^{300}$ it is worth noting that in 1965 , there was a substantial question as to whether confessions were necessary at all ${ }^{301}$-and Miranda's facts played into that perfectly. Indeed, the Supreme Court went out of its way to note in the Miranda opinion that "the cases before us present graphic examples of the overstatement of the 'need' for confessions." ${ }^{302}$ In a number of ways, then, the Supreme Court's decision in Miranda showed a remarkable sensitivity to crime control concerns-

${ }^{299}$ John P. MacKenzie, The Warren Court and the Press, in THE WARREN CourT: A CRITICAL ANALYSIS 112, 120-21 (Richard H. Sayler et al. eds. 1969) (discussing Johnson v. New Jersey, 384 U.S. 719, 721 (1966)). Commentators have viewed the Supreme Court's retroactivity ruling in Johnson as clearly political, evidencing the Court's willingness to retreat when the implications of a ruling were more than the nation could bear. See, e.g., PowE, supra note 12, at 428 (characterizing the Court's decisions as recognizing that if Miranda meant emptying jails, "then Miranda, not the prisoners, would have ... to go"); WASBY, supra note 12, at 189 (interpreting the Court's refusal to apply Miranda retroactively as signifying that it was "willing to retreat or modify the thrust of its opinions when its liberalism was more than the public (and particularly important publics like the law enforcement community) could take"); Anthony Lewis, Earl Warren, in THE WARREN COURT: A CRITICAL ANALYSIS, supra, at 1, 25 (describing the Court's nonretroactivity ruling as reflecting its "desire to lay down a broad new rule without worrying the public about emptying the jails").

${ }^{300}$ See Gerald M. Caplan, Questioning Miranda, 38 VAND. L. REV. 1417, 1427 n.50 (1985) (noting that the facts of the Court's earlier confession cases were "as appalling ... as [those in] Miranda were benign"). Indeed, Miranda's attorney conceded at oral argument that the police conduct at issue met the Court's voluntariness standard. See Oral Argument, Miranda v. Arizona, 384 U.S. 436 (1966) (No. 759), reprinted in 63 LANDMARK BRIEFS, supra note 83, at 853 ("We have raised no question that he was compelled to give this statement, in the sense that anyone forced him to do it by coercion, by threats, by promises, or compulsion of that kind.").

${ }^{301}$ See, e.g., Steven V. Roberts, Confessions Held Crucial By Hogan, N.Y. TimEs, Dec. 2, 1965, at 1 (reporting the Manhattan district attorney's claim that confessions were crucial in $27 \%$ of his homicide cases, while noting that this figure was "considerably below" the $50 \%$ figure usually cited by law enforcement officials); Zion, supra note 251, at 1 (reporting a study by New York State Supreme Court Justice Nathan Sobel concluding that fewer than $10 \%$ of indictments involved confessions, rendering law enforcement claims as to the necessity of confessions "carelessly nurtured nonsense"); Sidney E. Zion, So They Don't Talk, N.Y. Times, Aug. 21, 1966, at B13 (noting that Detroit's chief of detectives had "produced statistics showing that the need for confessions had been vastly overestimated"); Zion, supra note 240, at 90 (noting that "district attorneys have no statistics to back up their claim that most murderers and rapists would walk out of the police stations, thumb to nose, if confessions were banned").

${ }^{302}$ Miranda, 384 U.S. at 481. 
so much so that Justice Clark almost made the Court's ruling six to three, rather than five to four. ${ }^{303}$

\section{A Closer Look at Evidence of Miranda's Countermajoritarian Nature}

In light of the above discussion, the evidence commonly cited as proof of Miranda's countermajoritarian nature is perplexing to say the least. After all, if the Court's ruling was truly in keeping with contemporary notions of acceptable law enforcement reform, how could it have been so unpopular? In part, the answer is that Miranda was not as unpopular as we have tended to think. The amicus brief signed by twenty-six state attorneys general, for example, voiced no opposition whatsoever to a general warning requirement prior to custodial interrogation. ${ }^{304}$ Instead, the brief opposed extending the Sixth Amendment right to counsel to the custodial interrogation stage (a wellfounded fear given Escobedo two years earlier) and urged the Court to leave reform in the area of police interrogation to non-constitutional decision-making bodies like the ALI. ${ }^{305}$ Given the ALI's position on custodial interrogation at that time, ${ }^{306}$ there is no reason to believe the attorneys general would have opposed even constitutional adjudication of the issues in Miranda, had they known where the Court was actually heading.

Even more intriguing was the law enforcement community's immediate reaction to Miranda. Given the hostile tenor of the Court's opinion and the additional protections for criminal defendants that the decision imposed, it was entirely predictable that police would

${ }^{303}$ Justice Clark initially voted with the majority in conference, agreeing on the necessity of the same four warnings ultimately imposed in the case. THE SUPREME COURT IN CONFERENCE, supra note 86, at 516-17. Ultimately, he wrote a separate dissent in the case because he decided that the Court's decision in Miranda went "too far, too fast," while the dissenters' position was also unsatisfying. Id. at 518; see also Miranda, 384 U.S. at 499 (Clark, J., dissenting) ("I am unable to join the majority because its opinion goes too far on too little, while my dissenting brethren do not go quite far enough.").

${ }^{304}$ Brief of Amici Curiae State of New York et al. at 4-5, Miranda v. Arizona, 384 U.S. 436 (1966) (No. 759), reprinted in 63 LANDMARK BRIEFS, supra note 83, at 788, 79192.

${ }^{305}$ See id. at 5 (arguing that "[p]rocedural developments in th[e] area [of confessions] should take place in non-constitutional terms" through state courts, legislatures, professional organizations, and reform organizations such as the American Law Institute).

See supra note 260 and accompanying text (discussing warnings requirement in ALI's draft Model Code). 
complain bitterly about Miranda-and many did. ${ }^{307}$ What is surprising is just how muted their response generally was. As reported on the front page of the New York Times, the law enforcement community's initial reaction to Miranda was "mild;" in fact, police spokesmen across the country stated they could "learn to live with" the new warnings requirement. $^{308}$ Perhaps the surprisingly muted response from these spokesmen was due to the fact that they, like the attorneys general, had anticipated a much stronger ruling from the Court. Just as likely, however, was the fact that, as the New York Times pointed out, many precincts had already employed warnings and thus knew suspects would frequently waive their rights. ${ }^{309}$ Indeed, James Vorenberg, thenexecutive director of the National Crime Commission, told the press that Miranda would have little, if any, negative effect on law enforcement because it merely moved the voluntariness inquiry from the confession to the waiver context and "the police have done pretty well with these swearing contests over the years." ${ }^{310}$ In short, many in law enforcement breathed a sigh of relief when Miranda was decided, though their opinion one way or the other was hardly an indication of what the public at large thought of the decision.

The public opinion poll data on Miranda, which at least purported to measure the average citizen's views of the decision, is a different matter altogether. Concededly, the 1966 Harris and Gallup polls appear to provide powerful evidence of Miranda's countermajoritarian nature, though upon closer inspection, there is reason to question whether either should be given much weight. In November 1966, four months after Miranda was decided, a nationwide Harris poll

307

See, e.g., Crime and the Law: The Court on Confessions, N.Y. TIMES, June 19, 1966, D1, at 1 (quoting a police chief as saying, "[w]e might as well close up shop"); Rewriting the Rules, NEWSWEEK, June 27, 1966, at 21, 22 (noting executive director of the International Association of Chiefs of Police's statement that "I guess now we'll have to supply all squad cars with attorneys"); Zion, supra note 273, at A1 (reporting Brooklyn district attorney's comment that Miranda had "effectively shackled" law enforcement, while noting his remarkably different position on the issue the previous fall); Zion, supra note 301, at E13 (commenting that Miranda caused most law enforcement officials to sing the "[w]e've got the handcuffed, hamstrung, might-as-well-close-up-shop blues").

${ }_{908}$ Graham, supra note 265, at 1 ("The nation's police can learn to live with the new confessions limitations set by the Supreme Court, a check of law enforcement officials indicated today. Reaction across the nation to yesterday's decision was regarded in legal circles here as mild."); see also Crime and the Law, supra note 307, at Al (noting that the law enforcement response to Miranda was "more muted than usual" and that some in law enforcement were saying that the Supreme Court's ruling had little meaning because they had been warning suspects prior to custodial interrogation all along).

${ }^{309}$ Crime and the Law, supra note 307 , at 1 ; Graham, supra note 265 , at 1.
${ }^{310}$ Graham, supra note 265 , at 28 . 
asked: "Another decision of the U.S. Supreme Court was to ... rule that the police could not question a criminal unless he had a lawyer with him. Do you personally think that decision of the U.S. Supreme Court was right or wrong?"311 Answering that question, $35 \%$ of those surveyed said they believed the decision was right, while $65 \%$ believed it was wrong ${ }^{312}$-a result others have cited as proof of the public's overwhelming disapproval of Miranda's holding. ${ }^{313}$ Thus far overlooked, however, is the fact that the Harris Poll's question inaccurately represented what the Court in Miranda actually held. Setting aside its reference to interrogation suspects as "criminals," the question incorrectly portrayed Miranda's ruling as requiring counsel during custodial interrogation, a move that not even the Court in Escobedo had contemplated. $^{814}$ That being the case, the most revealing aspect of the Harris Poll's question on Miranda may be that even after misrepresenting the Court's ruling as more aggressively protective than it was, $35 \%$ of those surveyed still agreed with it-an impressive figure, but not as evidence of Miranda's dearth of public support.

Although the 1966 Gallup Poll's question on Miranda was at least technically correct (or close), its results are likewise questionable as evidence of Miranda's countermajoritarian nature. In July 1966, just a month after the Supreme Court decided Miranda, Gallup asked the following in a nationwide survey:

The Supreme Court has ruled that as soon as the police arrest a suspect, he must be warned of his right to remain silent and to have a lawyer. Only if he voluntarily waives these rights may the police question him. If he wants a lawyer, but cannot afford one, the State must pay the fee. The lawyer has a right to be present during the questioning and advise the suspect to say nothing. The following question was asked of those who said they followed the issue (about four persons in ten in the

${ }^{311}$ Louis Harris and Associates, Harris Survey, Nov. 14, 1966, Question ID USHARRIS.111466 R2E. The ellipsis is in the original text, reflecting the survey's incorporation of several different Supreme Court rulings into one question. Id.

${ }^{312} I d$.

${ }^{313}$ See, e.g., CraY, supra note 59, at 480 (discussing the Harris Poll results); G. Theodore Mitau, Decade of Decision: The Supreme Court and the ConstiTUTIONAL REVOLUTION 1954-1964, at 7 (1967) (same).

${ }^{314}$ At most, Escobedo contemplated extending Gideon's right to an attorney to the custodial interrogation setting. See supra text accompanying note 233 (discussing the broad implications of the Escobedo holding). Yet not even Gideon required defendants to have an attorney; it just entitled them to one upon request. See Gideon v. Wainwright, 372 U.S. 335, 340, 342-45 (1963) (explaining that "in federal courts counsel must be provided for defendants unable to employ counsel unless the right is competently and intelligently waived," and extending that requirement to state criminal cases under the Fourteenth Amendment). 
sample): Do you think the Supreme Court's ruling on confession was good or bad? ${ }^{315}$

In response, $30 \%$ of those surveyed said they had no opinion on the Court's ruling, $24 \%$ said they thought the ruling was good, and $46 \%$ said they thought the ruling was bad. ${ }^{316}$ By comparison, Gallup's results were weaker than those reported by Harris-only $40 \%$ of those surveyed actually followed the issue, and of those who did, $54 \%$ either had no opinion or actually approved of the Miranda decision. Yet Gallup's phraseology was misleading too. Although the question correctly noted that states would have to pay for attorneys provided to indigent suspects during custodial interrogation and that those attorneys could advise their clients to say nothing, not even the Miranda majority had envisioned its ruling working out that way in practice. As the Miranda opinion made clear, police were not constitutionally required to provide indigent suspects with lawyers upon request so long as they stopped questioning them. ${ }^{317}$ Because lawyers would presumably tell their clients to say nothing, ${ }^{318}$ halting the interrogation process was the only course of action that made sense when suspects invoked their right to counsel-and the FBI's experience showed that is exactly what interrogators did. ${ }^{319}$ Thus, although Gallup's portrayal of Miranda may not have been inaccurate, neither was it realistic or even neutral in presenting the decision for public approval.

That said, there was another public opinion poll on Miranda in the summer of 1966 that has yet to receive scholarly recognition, but should. Just after Miranda was decided, the National Opinion Research Center (NORC) told participants in its nationwide survey: "The Supreme Court has recently ruled that in criminal cases the police may not question a suspect without his lawyer being present,

\footnotetext{
3153 GALLUP, supra note 294, at 2021.

${ }^{316}$ Id.

${ }^{317}$ The Court stated:
}

This does not mean, as some have suggested, that each police station must have a 'station house lawyer' present at all times to advise prisoners.... If authorities conclude that they will not provide counsel during a reasonable period of time in which investigation in the field is carried out, they may refrain from doing so without violating the person's Fifth Amendment privilege so long as they do not question him during that time.

Miranda, 384 U.S. at 474.

${ }^{318}$ See Watts v. Indiana, 338 U.S. 49, 59 (1949) (Jackson, J., concurring in part and dissenting in part) ("[A]ny lawyer worth his salt will tell the suspect in no uncertain terms to make no statement to police under any circumstances.").

${ }^{319}$ See Miranda, 384 U.S. at $485-86$ (noting the FBI's practice of halting interrogation upon a defendant's request for the advice of counsel). 
unless the suspect agrees to be questioned without a lawyer. Are you in favor of this Supreme Court decision or opposed to it?" still firmly convinced that Miranda was countermajoritarian, the results may be surprising: $65 \%$ of those surveyed said they were in favor of the Court's ruling, while $35 \%$ opposed it. ${ }^{321}$ Granted, even the NORC's question failed to provide a fully accurate depiction of the Court's ruling in Miranda; like the Harris Poll, it focused exclusively on the right-to-counsel aspect of the decision, ignoring the warnings component altogether. Yet what the question did say, it said in an accurate and neutrally phrased manner, which is more than the Harris Poll and Gallup Poll questions were able to accomplish. In my mind, the NORC Poll provides powerful evidence that the Supreme Court's decision in Miranda was more majoritarian than not. The point, however, is a smaller one. Taken as a whole, the public opinion poll data on Miranda falls substantially short of proving that the decision was countermajoritarian, at least at the time it was rendered.

Nothing stated so far is meant to suggest that Miranda remained a publicly acceptable decision for long. By 1968, Miranda was undeniably unpopular, though the results of the presidential election that year are less probative of that fact than others have made them out to be. ${ }^{322}$ Granted, in 1968, Richard Nixon ran for president-and won-on a "law and order" campaign that specifically targeted the Supreme Court's criminal procedure decisions as the cause of the nation's crime control problems. ${ }^{323}$ In 1968, however, "law and order" meant

320 NAT'L OPINION RESEARCh CTR., CRIMinal Victimization IN THE UNITED STATES 65 (1966).

${ }^{321} I d$.

322 See, e.g., BAKER, supra note 199, at 198 (crediting the election of Richard Nixon, an outspoken critic of Miranda, as evidence of the decision's unpopularity); ALEXANder M. Bickel, The Supreme COURT AND THE IDEA OF Progress 93 (1970) (characterizing the 1968 election as "something of a vote of repudiation" of the Warren Court's criminal procedure decisions); Garcia, supra note 203, at 478 (connecting Miranda with Nixon's successful exploitation of fear of crime in the 1968 presidential election); Stephen A. Saltzburg, The Flow and Ebb of Constitutional Criminal Procedure in the Warren and Burger Courts, 69 GEO. L.J. 151, 209 (1980) (attributing much of Nixon's support in the 1968 presidential campaign to his criticism of the Supreme Court's criminal procedure decisions).

${ }^{323}$ In May 1968, Nixon wrote a position paper on crime in which he blamed most of the country's woes on the Supreme Court. In that paper, he stated that the Court's decisions in Miranda and Escobedo "had the effect of seriously hamstringing the peace forces in our society and strengthening the criminal forces," concluding that "the cumulative impact of these decisions has been to set free patently guilty individuals on the basis of legal technicalities." BAKER, supra note 199, at 211 (quoting and discussing portions of Nixon's position paper). Nixon's position paper reiterated comments he had made in a November 1967 Reader's Digest article in which he blamed recent 
different things to different people. To some, "law and order" represented a backlash against skyrocketing crime rates; to others, it was a backlash against blacks rioting in the streets; and to others still, it was a backlash against blacks period. ${ }^{324}$ Even so, the 1968 election results had as much to do with Vietnam as they did "law and order," and Nixon barely won. ${ }^{325}$ In fact, his margin of victory was just $0.6 \%$ of the popular vote, one of the lowest ever recorded in a presidential race. ${ }^{326}$ Given those considerations, treating the 1968 presidential election as a referendum on Miranda is problematic to say the least.

The same cannot be said for the Omnibus Crime Control and Safe Streets Act of $1968,{ }^{327}$ which purported to legislatively overrule

Supreme Court decisions for "weakening the peace forces as against the criminal forces." Richard M. Nixon, What Has Happened to America?, READER's DIG., Oct. 1967, at 49, 50; see also CRAY, supra note 59, at 497 (discussing portions of the Reader's Digest article). This phrase would become the backbone of Nixon's standard stump speech in the 1968 campaign. See MATusow, supra note 133, at 401 (noting Nixon's comparison of "peace forces" and "criminal forces"); PowE, supra note 12, at 410 (same); see also Hall, supra note 127, at 293 (noting Nixon's promise during the 1968 campaign to appoint only "strict constructionists" to the Supreme Court, justices who would not coddle criminals); Nixon Links Court to Rise in Crime, N.Y. TIMES, May 31, 1968, at A18 (reporting Nixon's accusation that the Supreme Court has 'giv[en] the 'green light' to 'the criminal elements' in this country").

${ }^{324}$ See MATUSOW, supra note 133, at 401 ("A phrase splendid in its imprecision, law and order might intend as its targets students, blacks, criminals, or maybe all three. Let the hearer take his pick."); Mark Tushnet, The Warren Court as History: An Interpretation, in The Warren Court in Historical and Political Perspective 1, 19 (Mark Tushnet ed., 1993) ("As [Nixon] understood, the issue of 'crime in the streets' was a convenient vehicle for mobilizing white urban fears of African Americans; and by packaging the issue ... [as] attacks on the Warren Court's criminal procedure decisions, Republicans could capitalize on those fears without openly appealing to racism."); see also Russell Baker, Observer: Crime in the Whats?, N.Y. TIMES, Jan. 28, 1968, at E12 (“'[C]rime in the streets' is a white man's code phrase meaning 'niggers.”); Homer Bigart, Agnew Deplores Demonstrations, N.Y. Times, Sept. 14, 1968, at 16 (noting a caution from Nixon's supporters that "the phrase 'law and order' had taken on a connotation of racial repression"); Murray Schumach, Crime Statistics: A Numbers Game, N.Y. TIMES, Feb. 4, 1968, at 1 (reporting the view that "there is a tendency to make crime in the streets synonymous with racial threats or the need to control the urban Negro problem"' (quoting Dr. Kenneth B. Clarke)).

${ }^{225}$ See, e.g., Matusow, supra note 133, at 397 (describing Vietnam as "the issue which, more than any other, caused the bitter national mood in 1968").

${ }^{926}$ BAKER, supra note 199, at 257; THEODORE H. WHITE, THE MAKING OF THE PREsIDENT: 1968, at 396 (1969). By comparison, the 2000 presidential race had a popular vote margin of $0.5 \%$-in favor of losing candidate Al Gore. See David Stout, Gore's Lead in the Popular Vote Now Exceeds 500,000, N.Y. TIMES, Dec. 30, 2000, at A11 (noting that Gore received a plurality of about 500,000 votes nationwide, roughly $0.5 \%$ of the approximately 100 million votes cast).

${ }^{327}$ Pub. L. No. 90-351, 82 Stat. 197, $211-25$ (codified as amended at 18 U.S.C. $\$ \S 2510-2522(2000))$. 
Miranda and was passed by overwhelming margins in both the House and Senate. ${ }^{328}$ Granted, the Act provides significant proof that Miranda was unpopular in 1968-but that was 1968. Even in 1967, when the public's focus was turning away from civil rights and toward crime, ${ }^{329}$ the Southern-sponsored anti-Miranda measure had so little backing that it died without ever reaching the Senate floor. ${ }^{390}$ By the time the measure was resurrected and tacked onto the omnibus funding bill in the spring of 1968 , crime and lawlessness had become the nation's top domestic problem, and no one (least of all politicians in an election year) was willing to go on record against any measure promoting "law and order." "391 In short, the Omnibus Crime Control and Safe Streets Act may prove that Miranda was countermajoritarian in 1968, but it says nothing about Miranda as an example of the Court's inclination for countermajoritarian decision making. For that, one must return to 1966 and the historical context in which Miranda was decided.

In light of the discussion above, one point should be clear: Miranda was not the aggressively countermajoritarian decision scholars have thus far portrayed it to be. Granted, the decision was controversial; the nation's emerging crime-control concerns made that much a given. And granted, the Supreme Court in Miranda did act in a somewhat countermajoritarian fashion by imposing upon the states a

${ }^{328}$ See Powe, supra note 12 , at 408 (noting that the Act passed in the House by a vote of 369 to 17 and in the Senate by a vote of 72 to 4 ). The Act provided that confessions were admissible so long as they were voluntarily given, see 18 U.S.C. $\$ 3501$ (a) (2000). Nearly thirty years later, the Supreme Court finally found the Act to be ineffectual in its aim. See Dickerson v. United States, 530 U.S. 428, 432 (2000) (holding that the 1968 Act could not overrule Miranda).

329 See Clark, Confirmed, Plans a New Price Fixing Drive, N.Y. TIMES, Mar. 3, 1967, at 1 (quoting Attorney General Ramsey Clark as stating that "there may be a little more public concern and interest in crime today, particularly 'crime in the streets' as we call it, than there has been in the past"); see also infra notes 333-45 and accompanying text (discussing rising salience of crime in 1967, particularly in latter half of year).

${ }^{350}$ See BAKER, supra note 199, at 206 (discussing the fate of the anti-Miranda measure in the 1967 congressional term).

${ }^{331}$ See id. at 208 ("A number of congressmen were rumored to have voted for the $1968 \mathrm{Act}$ ], although they privately disapproved of it, because they could not afford to seem soft on crime in an election year ...."); see also Editorial, "Cruel Hoax": Veto Called For, N.Y. TIMES, June 7, 1968, at 38 (arguing that the vote on the omnibus bill was more about putting politicians on the record in favor of law and order than an endorsement of its substantive measures); Editorial, Flawed Anti-Crime Law, N.Y. TIMES, June 21, 1968, at 40 ("President Johnson's signature of the [Omnibus Crime Control Act] is more a surrender to public hysteria over crime in the streets than it is an expression of conviction that the bill represents a sound contribution to the defense of law and order."). 
requirement that few had espoused on their own. Even here, however, one can see the limitations in the Court's willingness to evoke countermajoritarian change. Though few states supported Miranda's mandate, elite legal opinion did-and popular opinion may have as well. Thus, to the extent Miranda presents an example of the Court acting in even a limited countermajoritarian fashion, it is the exception that proves the rule. Like the other decisions discussed in this Article, Miranda first and foremost exemplifies the Court's tendency to reflect the prevailing policy positions and socioeconomic currents of its time. That said, times change, and so did the tenor of the Warren Court's later landmark criminal procedure decisions.

\section{THE LATER YEARS}

To fully appreciate the Warren Court's later landmark criminal procedure decisions, it is important to note at the outset two points about the setting in which those decisions were made. First, the composition of the Warren Court reached its liberal height in June of 1967, when civil rights activist Thurgood Marshall replaced the more police-oriented Tom Clark. ${ }^{332}$ Though that change still left the Warren Court with three conservatives (Justices Harlan, Stewart, and White), its six liberal members at least positioned the Court for a predictably liberal outcome in any given criminal procedure case.

Second, the American public in 1967 became increasingly concerned about crime. As early as March of that year, papers noted the common perception, if not fact, that crime was a serious problem and growing steadily worse. ${ }^{399}$ By the fall of 1967 , crime had so completely captured the public's attention that President Johnson's advisors were urging him to have his picture taken with police officers just to associate himself with "law and order," which he did. ${ }^{334}$ That fall also saw

${ }^{332}$ See UROFSKY, supra note 34, at 73 (discussing Justice Marshall's NAACP leadership and noting that "thanks to his own knowledge of how blacks had been treated by the criminal justice system, he became one of the strongest advocates of rights for the accused"); Yale Kamisar, The Warren Court (Was It Really So Defense-Minded?), the Burger Court (Is It Really So Prosecution-Oriented?), and Police Investigatory Practices, in THE BURGER COURT: THE COUNTER-REvolution THAT WASN'T, supra note 173, at 62, 67 (noting Justice Marshall's 1967 replacement of "the more prosecution-oriented [Justice] Clark").

${ }^{333}$ See, e.g., Fred P. Graham, The Law: Hawks vs. Doves on Crime and the Courts, N.Y. TimES, Mar. 19, 1967, at E8 (noting " $t \mathrm{t}]$ he belief, if not the fact, that the crime problem is getting steadily worse" and that "the crime problem is very real, at least in the minds of many people").

${ }^{334}$ MATUSOW, supra note 133, at 215. 
prominent politicians like California Governor Ronald Reagan predicting that crime would be a major issue in the 1968 presidential election, ${ }^{355}$ and for good reason. As it turned out, the crime rate in 1967 rose $15 \%$ as compared to 1966 -an all-time high for the decade, at least until $1968 .{ }^{336}$ With 1967's rise in the crime rate at a level $50 \%$ higher than 1966's $10 \%,{ }^{397}$ it is hardly surprising that major periodicals like U.S. News $\mathcal{E} \mathcal{G}$ World Report were headlining America's "growing lawlessness" by the end of the year. ${ }^{338}$ Indeed, by early 1968, crime had eclipsed civil rights as America's top domestic problem-a first since public opinion polling began in the $1930 \mathrm{~s}^{339}$

Much of the public's focus on crime, at least in the latter half of 1967 , almost certainly stemmed from the race riots that occurred that summer. Although the Watts riot in Los Angeles had shocked everyone in the summer of 1965, and 1966 had seen a spate of smaller racial disorders, ${ }^{340}$ nothing the public had previously experienced could prepare it for the "long hot summer" of 1967. In 1967 alone, there were 164 racial disturbances, eight of which were bona fide riots serious enough to require calling in the National Guard. ${ }^{341}$ Much of the

${ }^{335}$ See Gladwin Hill, Reagan Says War is Election Issue, N.Y. TIMES, Sept. 29, 1967, at 25 (reporting California Governor Ronald Reagan's prediction that crime would be the number one issue in the 1968 election).

${ }^{936}$ See Fed. Bureau of InVESTIGation, U.S. DeP'T OF JUSTICE, UNiform CRIME REPORTS FOR THE UNITED STATES-1967, at 4 (1968) (reporting a 15\% increase in the crime rate for 1967); see also infra note 424 and accompanying text (reporting a $16 \%$ rise in the crime rate for 1968).

${ }^{337}$ See supra note 292 and accompanying text (discussing the 1966 crime rate).

${ }^{398}$ More Protests ... Growing Lawlessness--How Far Will it Go?, U.S. NEwS \& WORLD REP., Dec. 18, 1967, at 6.

${ }^{339}$ See 3 GALLUP, supra note 294, at 2107 (indicating that crime and lawlessness were mentioned almost twice as often as any other local problem); Poll Finds Crime Top Fear at Home, N.Y. TIMES, Feb. 28, 1968, at 29 (reporting that “[c]rime and lawlessness are viewed by the public as the top domestic problem facing the nation for the first time since the beginning of scientific polling in the mid-thirties, according to the latest Gallup Poll"); see also Baker, supra note 324, at E12 (noting that "[a]t a time when Americans agree upon so few issues, it is odd that there should be such unity of loathing for crime in the streets."); John Herbers, Crime: Rights Take a Back Seat, N.Y. TIMES, Feb. 11, 1968, at E3 (observing "the decisive, almost sudden, shift that has taken place in two political issues-crime and civil rights" and remarking that "[a]s crime has gone up as an issue civil rights have gone down, in almost direct proportion"); Schumach, supra note 324, at 1 (noting that President Johnson's attack on "rising crime and lawlessness' was the most strongly cheered point" in his State of the Union address).

${ }^{340}$ See EDSALl \& EDSALl, supra note 12, at 51 (discussing Watts and other urban riots).

See id. (characterizing eight of the 164 disorders in 1967 as "major" on the grounds that they involved "multiple fires, intensive looting, and reports of sniping; violence lasting more than two days; sizeable crowds; and use of National Guard'"). 
violence that year occurred in June and July, with July being the far more turbulent month of the two. In mid-July, rioting in Newark killed twenty-three people. Ten days later, Detroit set a record for the worst riot of the century, necessitating the state police, the National Guard, and, finally, the United States Army to restore order. ${ }^{342}$ Detroit's riot lasted six days and covered fourteen square miles of ghetto, leaving forty-three people dead and causing approximately forty-five million dollars in property damage. ${ }^{343}$ With so much death and destruction, it was only natural for the public, press, and politicians to become alarmed that the country was "rapidly approaching a state of anarchy" in the second half of $1967 .^{344}$ That is not to say that 1967's urban riots were wholly responsible for the nation's growing concern over crime, for President Johnson had focused on the problem before then. ${ }^{345}$ One can say, however, that the violence the nation witnessed in the summer of 1967 almost certainly factored into crime's rising salience over the course of that year.

If, as I have argued, the Supreme Court is moved by the same social and political currents that move the rest of society, one would expect the nation's focus on crime in the late 1960s to have produced more conservative rulings from the Court on criminal justice issues, despite its stronger than ever liberal membership. In fact, that is exactly what happened. Although the Warren Court's decisions in the late 1960 s were particularly liberal in some areas, ${ }^{346}$ its rulings on criminal procedure became remarkably conservative-so much so that Yale Kamisar has claimed in jest that there was not one Warren Court, but two. ${ }^{347}$ Whether the change in the Warren Court's criminal

${ }^{342}$ See WHITE, supra note 326, at 202 (1969) (discussing the Detroit riot).

${ }^{343}$ See id. (detailing the destruction wrought by the Detroit riot); MATUSOW, supra note 133, at 363 (same). By comparison, Watts left thirty-four people dead and caused property destruction of approximately forty million dollars. See PRESIDENT'S COMM'N ON LAW ENFORCEMENT AND ADMIN. OF JUSTICE, TASK FORCE REPORT: CRIME AND ITS IMPACT-AN ASSESSMENT 119 (1967) [hereinafter TASK FORCE REPORT ON CRIME].

${ }^{344}$ Max Frankel, Johnson Accused by G.O.P. in Rioting, N.Y. TIMES, July 25, 1967, at 1.

${ }^{345}$ See WALKER, supra note 108, at 202-04 (discussing President Johnson's efforts to combat crime in the mid-1960s); supra text accompanying note 293 (noting President Johnson's special message to Congress on crime in 1966).

${ }^{346}$ See, e.g., Brandenburg v. Ohio, 395 U.S. 444, 447-49 (1969) (per curiam) (interpreting the First Amendment in an unprecedented fashion to protect rights of free speech and press in context of subversive activities); Shapiro v. Thompson, 394 U.S. 618,638 (1969) (striking down waiting periods for welfare benefits).

${ }^{347}$ Kamisar, supra note 332, at 67 ("One might say there were two Warren Courts ...."); see Kamisar, supra note 59, at 116 ("In its final years, the Warren Court was not the same Court that had handed down Mapp or Miranda."). I tend to agree with Professor Kamisar's sentiment, though I believe Miranda was a part of the Court's 
procedure jurisprudence of the late 1960s was that stark is certainly debatable, but his point is well taken, and no decisions demonstrate it better than the last two landmarks of the criminal procedure revolution, Katz $v$. United States ${ }^{348}$ and Terry $v$. Ohio. ${ }^{349}$

\section{A. Katz v. United States: A Sign of Concession}

When the Supreme Court decided Katz v. United States in December 1967, Chief Justice Warren predicted it would be a "'milestone decision, ${ }^{\prime 350}$ and he was right. Today, we think of Katz as the touchstone of modern Fourth Amendment jurisprudence; no discussion of the criminal procedure revolution would be complete without it. Yet Katz deserves a place in the present analysis for another reason as well-it, too, presents a seemingly strong example of the Warren Court playing the role of countermajoritarian hero. In Katz, the Supreme Court abandoned its restrictive property-rights approach to the Fourth Amendment in favor of a more malleable and broader conception of Fourth Amendment rights based on an individual's "reasonable expectation of privacy." "\$31 Presumably, that required some courage in late 1967, when crime control was all the public could think about. After all, when the Court in Katz uttered those famous words, "the Fourth Amendment protects people, not places," ing primarily about guilty people, and guilty people had never been more unpopular. At the very least, then, Katz's expansion of Fourth

conservative turn. In my mind, Escobedo, rather than Miranda, marks the height of the Court's liberalism on criminal justice matters. See supra notes 243-53 and accompanying text (describing Miranda as a step back from where the Court appeared to be heading in Escobedo two years earlier).

348 U.S. 347 (1967)

349392 U.S. 1 (1968).

${ }^{350}$ See SCHWARTZ, supra note 62, at 718 (discussing the Katz decision).

${ }^{351} \mathrm{Katz}, 389$ U.S. at 360 . Ironically, the "reasonable expectation of privacy" terminology came from Justice Harlan's concurrence, not from the Court's opinion. See Katz, 389 U.S. at 361 (Harlan, J., concurring) ("My understanding of the rule that has emerged from prior decisions is that there is a twofold requirement, first that a person have exhibited an actual (subjective) expectation of privacy and, second, that the expectation be one that society is prepared to recognize as 'reasonable."). Within a year after Katz was decided, the Court recognized the term "reasonable expectation of privacy" as fairly characterizing the Fourth Amendment protection it had recognized in Katz. See Terry v. Ohio, 392 U.S. 1, 9 (1968) ("We have recently held that 'the Fourth Amendment protects people, not places,' and wherever an individual may harbor a reasonable 'expectation of privacy,' he is entitled to be free from unreasonable governmental intrusion." (quoting Katz, 389 U.S. at 351 (Harlan, J., concurring))).

${ }^{352} \mathrm{Katz}, 389$ U.S. at 351. 
Amendment protections appears to be a bold, liberal move against the backdrop of 1967's increasingly conservative times.

Surprisingly enough, however, Katz was anything but the bold, liberal decision it appears to be at first blush. All three of the Warren Court's conservatives joined in the Court's ruling, and one of them, Justice Stewart, wrote the majority opinion. Indeed, Katz would have been unanimous if Justice Black had not stubbornly refused to acknowledge that intangible objects like a conversation could receive Fourth Amendment protection, a stance the Court had rejected years before $^{853}$ and one that others would later point to as exemplifying Justice Black's overly rigid interpretive style. ${ }^{354}$ Thus, while we might like to think of Katz as a decision that moved against the prevailing currents of its time, in fact it was sufficiently mainstream to garner the support of the Warren Court's liberals and conservatives alike.

In part, understanding Katz's broad-based appeal requires understanding the doctrinal background against which it was decided. Though the Supreme Court in Katz abandoned nearly forty years of precedent when it overruled Olmstead $v$. United States, ${ }^{355}$ its shift from property rights to privacy as the basis of Fourth Amendment protection was not the monumental change one might think. As early as 1886, the Court referred to the Fourth Amendment's purpose as protecting "the sanctity of a man's home and the privacies of life," view that became popular several years later when Louis Brandeis coauthored an influential law review article on the subject. ${ }^{357}$ By the

${ }^{353}$ See Wong Sun v. United States, 371 U.S. 471, 480-84 (1963) (applying a Fourth Amendment analysis to the search and seizure of an intangible object); see also Berger v. New York, 388 U.S. 41, 51 (1967) (noting that the idea that only tangible objects can come within the Fourth Amendment's reach "ha[s] been negated by our subsequent cases").

See, e.g., UROFSKY, supra note 34, at 38 (criticizing Justice Black's position on the Fourth Amendment in Katz as "rigidly literal" and "absurd"); see also PowE, supra note 12 , at 404 (explaining that Justice Black's dissent in Katz was a result of the fact that "[h]e always eschewed the Fourth [ Amendment]'s rich history, owned no books discussing it, and focused instead on its use of that detested word 'reasonable' in its text." Roger Newman, Black's sympathetic biographer, noted that "'[Justice Black] became fixated with [the Fourth Amendment's] wording, not its significance." Id. (footnote omitted) (quoting Roger K. NEWMAN, HUGo BLACK: A BIOGRAPHY 554 (2d ed. 1997))).

${ }^{355} 277$ U.S. 438 (1928) (basing Fourth Amendment holding on whether physical intrusion occurred).

${ }^{356}$ Boyd v. United States, 116 U.S. 616, 630 (1886).

${ }^{357}$ See Samuel D. Warren, Jr. \& Louis D. Brandeis, The Right to Privacy, 4 HARV. L. REV. 193 (1890); see also Griswold v. Connecticut, 381 U.S. 479, 510 n.1 (1965) (Black, $\mathrm{J}$, dissenting) (crediting Brandeis and Warren's article for giving the phrase "right to 
time the Court decided Wolf $v$. Colorado ${ }^{358}$ in 1949 , the notion that privacy interests lay at the core of the Fourth Amendment was so widely accepted that even the Court's conservative opinion in that case acknowledged it. ${ }^{359}$ By 1961, the Court's opinion in Mapp v. Ohio ${ }^{360}$ was replete with references to the Fourth Amendment's "right to privacy," ${ }^{361}$ which other prominent decisions in the 1960s likewise recognized. ${ }^{362}$ In short, Katz was accepted in principle long before it was actually decided; the Court's property-rights approach had simply been a way of effectuating the Fourth Amendment's more nebulous privacy guarantee.

By 1967, however, it was clear that the Court's property rights approach to the Fourth Amendment had become outdated. In the late 1950 s, technological advances in eavesdropping equipment made it possible to overhear the most intimate of conversations without actually trespassing onto a person's property, ${ }^{363}$ and that led to Fourth Amendment decisions in the early- to mid-1960s that bordered on the absurd. Because Olmstead required a physical trespass to implicate the Fourth Amendment, ${ }^{364}$ the Court affirmed convictions where the police obtained evidence by attaching a listening device to the

privacy" currency); John D. Pomfret, On Privacy, N.Y. TIMES, Jan. 17, 1965, § 6 (Magazine) at E7 (noting that the privacy doctrine is grounded in an article by Warren and Brandeis).

338 U.S. 25 (1949).

${ }^{359}$ See id. at 27 ("The security of one's privacy against arbitrary intrusion by the police-which is at the core of the Fourth Amendment-is basic to a free society.").

367 U.S. 643 (1961).

${ }^{361} I d$. at 655-57.

${ }^{362}$ See, e.g., Berger v. New York, 388 U.S. 41, 53 (1967) (referring to "the Fourth Amendment's right of privacy"); Camara v. Municipal Court, 387 U.S. 523, 528 (1967) (recognizing the basic purpose of the Fourth Amendment as safeguarding the privacy of individuals against arbitrary invasion by the government); Warden v. Hayden, 387 U.S. 294, 304 (1967) (recognizing that "the principal object of the Fourth Amendment is the protection of privacy rather than property"); Griswold v. Connecticut, 381 U.S. 479, 484-85 (1965) (citing Mapp for the proposition that the Fourth Amendment embodies a "right to privacy").

${ }^{363}$ See Lopez v. United States, 373 U.S. 427, $466-67$ (1963) (Brennan, J., dissenting) (noting that the electronic surveillance problem has "grown enormously in recent years" and citing congressional hearings from the late $1950 \mathrm{~s}$ in support of that proposition); Silverman v. United States, 365 U.S. 505, 508-09 (1961) (discussing recent developments in the technology of eavesdropping equipment not involving physical invasions).

${ }^{364}$ See Olmstead v. United States, 277 U.S. 438, 466 (1928) (requiring “an actual physical invasion of [a defendant's] house "or curtilage" for a Fourth Amendment violation); see also Lopez, 373 U.S. at 438-39 (noting that the Court's prior Fourth Amendment cases have "insisted only that the electronic device not be planted by an unlawful physical invasion of a constitutionally protected area."). 
defendant's outer wall, and reversed where the evidence was obtained by a device that penetrated it. ${ }^{365}$ In one case, the Court even found a Fourth Amendment violation where the police had used a "spike mike" that breached the outer wall of a defendant's home by a fraction of an inch, ${ }^{366}$ allowing critics to claim (and rightly so) that the difference between Fourth Amendment protection and none was a thumb-tack's length. ${ }^{367}$ Of course, such distinctions were absolutely irrelevant to the real point of the Fourth Amendment, which was and always had been the protection of privacy.

Clearly, Olmstead's property rights approach no longer made sense as a means of effectuating the Fourth Amendment's privacy guarantee, and (almost) everyone on the Supreme Court knew it. In the years before Katz was decided, the Court repeatedly denounced the use of property rights to define Fourth Amendment protections, even while its rulings continued to conform to that result. ${ }^{368}$ Indeed, the Court's repudiation of Olmstead was so complete that at least two Justices believed the 1928 decision had been overruled sub silentio

${ }^{365}$ Compare Goldman v. United States, 316 U.S. 129, 135 (1942) (finding no Fourth Amendment violation where police obtained evidence by pressing a "detectaphone" against the outside wall of the defendant's room), with Silverman, 365 U.S. at 506-07, 512 (finding a Fourth Amendment violation where a "spike mike" extended several inches into defendant's side of wall). See also Fred P. Graham, High Court Eases Curbs on Bugging; Adds Safeguard, N.Y. TIMES, Dec. 19, 1967, at Al (noting the ironic results in the Court's prior eavesdropping cases due to technological advances).

${ }^{366}$ See Clinton v. Virginia, 377 U.S. 158 (1964) (Clark, J., concurring) (joining the decision because the "spiked' mike used by the police officers penetrated petitioner's premises sufficiently to be an actual trespass thereof"), summarily rev'g Clinton v. Commonwealth, 130 S.E.2d 437, 442 (Va. 1963) (noting the "very slight" penetration of the device in the wall, "such as one made by a thumb tack").

${ }^{367}$ See GRAHAM, supra note 41, at 255 (“[A] thumb-tack's length could separate an individual from the protection of the Bill of Rights.").

${ }^{968}$ For example, in Silverman, the Court said:

Inherent Fourth Amendment rights are not inevitably measurable in terms of ancient niceties of tort or real property law... But decision here does not turn upon the technicality of a trespass upon a party wall as a matter of local law. It is based upon the reality of an actual intrusion into a constitutionally protected area.

Silverman, 365 U.S. at 511-12 (citations and footnotes omitted); see also Warden v. Hayden, 387 U.S. 294, 304 (1967) ("The premise that property interests control the right of the Government to search and seize has been discredited."); Lopez, 373 U.S. at 45859 (Brennan, J., dissenting) ("I think it is demonstrable that Olmstead was erroneously decided, that its authority has been steadily sapped by subsequent decisions of the Court, and that it and the cases following it are sports in our jurisprudence which ought to be eliminated."). 
before Katz was even decided. ${ }^{369}$ When Katz finally did overrule Olmstead, the Court's rationale was both predictable and difficult to dispute: Olmstead's authority had been "so eroded" by subsequent decisions that it could no longer be recognized as controlling. ${ }^{370}$ It would appear, then, that Justice Fortas was exactly right when he claimed a few years later that "Katz [wa]s not responsible for killing Olmstead." ${ }^{371}$ By the time Katz was decided, Olmstead was already dead.

Even so, Olmstead's much anticipated demise provides only half of the reason police-oriented conservatives would have supported $\mathrm{Katz}$ in 1967; the rest involves contemporary expectations of how electronic eavesdropping would fare if subjected to Fourth Amendment scrutiny. Prior to Katz, the prevailing view was that if the Fourth Amendment applied to electronic eavesdropping, the practice would never pass constitutional muster because it could never meet the Warrant Clause's particularity requirement. ${ }^{372}$ That requirement provides that

${ }^{369}$ See Berger v. New York, 388 U.S. 41, 64 (1967) (Douglas, J., concurring) ("I join the opinion of the Court because at long last it overrules sub silentio Olmstead $v$. United States and its offspring and brings wiretapping and other electronic eavesdropping fully within the purview of the Fourth Amendment." (citation omitted)). As Justice Black asserted in his dissent:

[T] he Court's opinion leaves the definite impression that all eavesdropping is governed by the Fourth Amendment. Such a step would require overruling of almost every opinion ... on the subject.... [I]t does not take too much insight to see that the Court is about ready to do, if it has not today done, just that.

Id. at 82 (Black, J., dissenting).

${ }^{370}$ Katz, 389 U.S. at 353.

${ }^{371}$ Desist v. United States, 394 U.S. 244, 275 (1969) (Fortas, J., dissenting) ("In any event, there is no doubt that Olmstead was thoroughly repudiated by this Court long before... Katz was decided. Katz is not responsible for killing Olmstead. Prior cases had left the physical-trespass requirement of Olmstead virtually lifeless and merely awaiting the death certificate that Katz gave it."); see also id. at 273 ("Katz did no more than administer the coup de grace to [Olmstead's] moribund doctrine.").

${ }^{372}$ Justice Brennan's 1963 dissent in Lopez recognized the point when he argued that the unarticulated reason for the property rights approach

is the pervasive fear that if electronic surveillance were deemed to be within the reach of the Fourth Amendment, a useful technique of law enforcement would be wholly destroyed, because an electronic 'search' could never be reasonable within the meaning of the Amendment. For one thing, electronic surveillance is almost inherently indiscriminate, so that compliance with the requirement of particularity in the Fourth Amendment would be difficult . . . .

Lopez v. United States, 373 U.S. 427, 463 (1963) (Brennan, J., dissenting) (citation omitted); see also GRAHAM, supra note 41, at 253 (noting that "the rules for warrants were so strict that they seemed to preclude a valid warrant to wiretap" and discussing the Warrant Clause's particularity requirement); Herman Schwartz, The Legitimation of Electronic Eavesdropping: The Politics of "Law and Order", 67 Mich. L. Rev. 455, 457 (1969) (noting that " $[t]$ he chief argument against the constitutionality of most kinds 
all warrants must "particularly describ[e] the place to be searched, and the persons or things to be seized," when it comes to electronic eavesdropping because the conversation to be seized had not yet occurred. At best, police can articulate what they hope to hear, but the fact of the matter is that electronic eavesdropping indiscriminately "seizes" every word spoken, whether or not it is relevant to the investigation underway. ${ }^{374}$ Arguably recognizing the point, the Court's mid-1967 decision in Berger $v$. United States ${ }^{375}$ invalidated a New York statute that authorized court-approved wiretapping because its provisions were insufficient to satisfy the Warrant Clause's particularity demands. ${ }^{376}$ Thus, prior to Katz, there was reason to believe that if the basis of the Court's Fourth Amendment jurisprudence shifted from property rights to privacy, electronic eavesdropping would become unconstitutional per se.

Even in 1966, before Berger was decided, commentators considering the Warren Court's concern for protecting individual liberties predicted that the Justices would eventually declare the so-called "dirty business" of electronic eavesdropping unconstitutional. ${ }^{377}$ What is

of eavesdropping is that the resulting search and seizure is unavoidably too sweeping to comply with the particularity requirements of the Fourth Amendment" (footnote omitted)). This is not to say that the particularity requirement was the only problem with applying the Fourth Amendment to electronic eavesdropping, for the prohibition against searches for "mere evidence" would have prohibited the practice as well. That obstacle, however, was removed by the Court's decision in Warden v. Hayden several months before Katz was decided. See Warden v. Hayden, 387 U.S. 294, $306-07$ (1967) ("The requirements of the Fourth Amendment can secure the same protection of privacy whether the search is for 'mere evidence' or for fruits, instrumentalities or contraband.").

${ }^{373}$ U.S. CONST. amend. IV.

374 See Schwartz, supra note 372 , at 457 (noting that electronic surveillance techniques are incapable of separating irrelevant or privileged information from the information actually sought).

375 388 U.S. 41 (1967).

${ }^{376}$ See id. at 56-58 (invalidating the New York statute, but suggesting that a more carefully drawn provision might pass constitutional scrutiny); see also Graham, supra note 365, at Al (noting that Berger had created the impression that the Court would impose "impossible restrictions" on police eavesdropping); Fred P. Graham, A Plug in the 'Big Ear', N.Y. TIMES, Dec. 24, 1967, at E10 [hereinafter Graham, 'Big Ear'] (noting that after Berger, many assumed the Court would limit bugging with so many legal technicalities that "almost any useful eavesdropping would be deemed unconstitutional"). But see Curb on Eavesdropping, N.Y. TIMES, June 21, 1967, at 46 (noting that the Court's decision in Berger "stops far short of a total ban on the use of electronic devices in the war against crime" and "leaves the door open for passage of a more carefully drawn statute").

${ }^{377}$ See, e.g., Harold J. SPAETh, The WaRREN COURT: CASES AND COMmENTARY 299 (1966) (“[G]iven the Warren Court's concern to protect civil liberty, it is not unlikely 
intriguing about Katz, and what made the decision eminently appealing to the Court's conservatives, was that the Supreme Court did just the opposite. After reversing Katz's conviction because the police intruded upon his reasonable expectation of privacy in a closed telephone booth, the Court added what the press would call "a surprising postscript": ${ }^{378}$ if the officers had simply obtained a warrant first, their actions would have been constitutionally permissible. ${ }^{379}$ In one short paragraph, the Court erased years of unease with the notion of subjecting electronic eavesdropping to Fourth Amendment scrutiny by reassuring all concerned that the practice could nevertheless survive it-and that was major news. In fact, the headline of the front page New York Times article on Katz read "High Court Eases Curbs on Bugging; Adds Safeguard," while the subheadline declared, "Insists Police Must Obtain Warrant to Act-Doesn't Forbid Eavesdropping." ${ }^{380}$ Granted, on page thirty, the Times also mentioned that the Court had "upheld" privacy rights, ${ }^{381}$ but in 1967, the significance of Katz was clearly not the same as it is today. In 1967, Katz was a pro-law enforcement decision that surprised everyone by giving the Court's blessing to judicially authorized electronic eavesdropping.

Given the sociopolitical context in which Katz was decided, the Warren Court's approval of court-ordered electronic eavesdropping was, at least in retrospect, not so surprising after all. In early 1967, the

that wiretap evidence will eventually be ruled inadmissible."); see also Olmstead v. United States, 277 U.S. 438, 470 (1928) (Holmes, J., dissenting) (referring to wiretapping as "dirty business").
${ }^{378}$ Graham, 'Big Ear', supra note 376, at E10.
${ }^{379}$ The Katz opinion stated:
[I]t is clear that this surveillance was so narrowly circumscribed that a duly authorized magistrate, properly notified of the need for such investigation, specifically informed of the basis on which it was to proceed, and clearly ap- prised of the precise intrusion it would entail, could constitutionally have authorized, with appropriate safeguards, the very limited search and seizure that the Government asserts in fact took place.

Katz, 389 U.S. at 354.

${ }^{380}$ Graham, supra note 365 , at 1 . The article's first sentence read "[ $\left.\mathrm{t}\right]$ he Supreme Court made it clear today that the Constitution does not forbid electronic bugging by law enforcement officers if they first obtain warrants authorizing the eavesdropping." Id. Of course, the press's interpretation of Katz was completely beyond the Supreme Court's control, but the Court knew full well (and had for years) that the real question in moving from a property-rights to a privacy rationale for Fourth Amendment protection was how that move would affect the constitutionality of electronic eavesdropping. See supra notes 372-76 and accompanying text (discussing fear that adopting a privacy approach to the Fourth Amendment would render eavesdropping unconstitutional per se).

${ }^{381}$ Graham, supra note 365 , at 30 . 
National Crime Commission issued a report addressing the inherent difficulties associated with investigating and prosecuting organized crime, noting that electronic eavesdropping was considered "'the single most valuable weapon'" police had. ${ }^{382}$ Though the problem of organized crime had received considerable attention from the federal government and the press throughout the $1960 \mathrm{~s},{ }^{383}$ the National Crime Commission's report was particularly important for three reasons. First, it was the government's first attempt to examine the problem and possible solutions in a comprehensive manner. Second, it came at a time when the country as a whole was becoming preoccupied with crime. Finally, and perhaps most importantly, it came just as the Court's property rights approach to the Fourth Amendment had proven itself incapable of dealing with advances in electronic eavesdropping equipment. Given the National Crime Commission's 1967 findings and the crime-conscious tenor of the times, it is hard to fathom the Supreme Court rendering a decision that would have effectively outlawed electronic eavesdropping altogether. ${ }^{384}$

382 PRESIDENT'S COMM'N ON LAW ENFORCEMENT \& ADMIN. OF JUSTICE, THE CHALlENGE OF CRIME IN A FREE SOCIETY 201 (1967) [hereinafter NAT'L CRIME COMM'N REPORT] (quoting the testimony of a New York County District Attorney). In part, the importance of electronic eavesdropping stemmed from the fact that highechelon Mafia leaders participated in crimes only by orally ordering others to commit them. See id. ("High-ranking organized crime figures are protected by layers of insulation from direct participation in criminal acts ...."). In part, the importance of electronic eavesdropping had to do with the unique dynamics of investigating organized crime. Ordinarily, police investigations start with a known crime and work back to an unknown criminal, but in organized crime investigations the reverse is often true-police start with a known criminal and work back (or forward) to an unknown crime. See Schwartz, supra note 372 , at 469 (discussing unique challenges of investigating and prosecuting organized crime).

${ }^{383}$ President Lyndon B. Johnson, Special Message to Congress on Crime and Law Enforcement (Mar. 9, 1966), in 1 PuB. PAPERS 291, 294 (reprinting President Johnson's claim in his 1966 special message on crime that "[ $t]$ he most flagrant manifestation of crime in America is organized crime"); GRAHAM, supra note 41, at 249 (noting the Kennedy Administration's "strong prosecutorial interest" in the nationwide activities of organized crime); PowE, supra note 12, at 402 (discussing Attorney General Robert Kennedy's “Get Hoffa Squad" in the early 1960s); Charles Grutzner, Mafia Steps Up Infiltration and Looting of Businesses, N.Y. TIMES, Feb. 14, 1965, at 1 (reporting a Senate subcommittee's probe into the Mafia's widespread infiltration of American businesses and industry); Emanuel Perlmutter, Robert Kennedy Cites Rise in Crime, N.Y. Times, Sept. 26, 1963, at 1 (reporting Attorney General Robert Kennedy's description of syndicated crime as a "grave national problem").

${ }^{384}$ Even the Court's decision in Berger hinted in dicta that other laws might be sufficiently exacting to meet the Fourth Amendment's demands. See Berger, 388 U.S. at 56-58 (suggesting that a statute containing precise requirements for the use of electronic eavesdropping might meet the Fourth Amendment's requirement of particularity); see also supra note 376 (noting mixed perceptions of Berger's significance). 
Interestingly enough, the National Crime Commission's 1967 report was salient (and convincing) enough to spawn legislative efforts to do exactly what the Supreme Court did in Katz: authorize courtapproved wiretapping. In 1934, Congress outlawed the practice of wiretapping, which at the time was considered outside the purview of the Fourth Amendment because it required no physical trespass to effectuate. $^{385}$ Over time, technological advances in electronic eavesdropping equipment outflanked the 1934 wiretapping statute just as they had the Court's Fourth Amendment jurisprudence, resulting in a host of surveillance techniques not prohibited by the statute because they were technically not wiretapping practices at all. ${ }^{386}$ Based on the National Crime Commission's 1967 report, ${ }^{387}$ Congress was in the process of closing that loophole while relaxing its wiretapping ban when the Supreme Court decided Katz. Legislation pending when Katz was decided proposed expanding the 1934 statute's reach to other constitutionally permissible electronic eavesdropping practices while making all of them (including wiretapping) permissible only if police first obtained a warrant. ${ }^{388}$ In short, the Supreme Court's decision in Katz imposed the exact same restrictions on electronic eavesdropping that Congress was then contemplating, and in fact imposed a mere six months later. ${ }^{389}$

It is difficult to say whether the Supreme Court's decision in Katz was a conscious response to the nation's needs at that time or an

${ }^{385}$ See 47 U.S.C. $\$ 305$ (1934) (defining wiretapping and barring use of evidence obtained thereby in federal courts).

386 See NAT'L CRIME COMM'N REPORT, supra note 382, at 202-03 (concluding that "[a]t the present time there is no Federal legislation explicitly dealing with bugging"); GRAHAM, supra note 41, at 254-55 (noting that new electronic surveillance techniques "were largely outside the reach of the law").

${ }^{387}$ See NAT'L CRIME COMM'N REPORT, supra note 382, at 203 ('A majority of the members of the Commission believe that legislation should be enacted granting carefully circumscribed authority for electronic surveillance to law enforcement officers to the extent it may be consistent with the decision of the Supreme Court in People $v$. Berger....").

${ }^{388}$ See GRAHAM, supra note 41 , at 267-69 (discussing the political context in which Katz was decided, including the proposed amendments to the 1934 wiretapping statute then pending in Congress); Graham, supra note 376, at 10E (reporting the Katz decision while noting that "[a] bill to authorize court-supervised police eavesdropping is already before the Senate Judiciary Committee, and the Katz decision is certain to help it along.").

${ }^{389}$ See GraHAM, supra note 41, at 268 (noting that the Omnibus Crime Control and Safe Streets Act of 1968 authorized for the first time "court-approved wiretapping and bugging to gather evidence"). 
unconscious reflection of the national mood. ${ }^{390}$ With Congress contemplating legislation on electronic eavesdropping and newspapers characterizing the Court's earlier decision in Berger as "politically hazardous, ${ }^{, 991}$ the Justices were undoubtedly under pressure to avoid what seemed to be an impending constitutional ban on electronic eavesdropping altogether. On the other hand, the "law and order" mood of late 1967 may well have subconsciously pulled the Court toward the result in Katz anyway. Whatever the reason, the same Supreme Court known for taking a dim view of police practices that impinged upon individual liberties went out of its way to make an important concession to the police when that was what the nation wanted. No doubt, the Court's 1967 decision in Katz "tapped into" dominant public opinion at the time, even while liberalizing the Fourth Amendment's foundational precepts. Even more in keeping with the times, however, was the last major landmark decision to come, Terry v. Ohio. ${ }^{392}$

\section{B. Terry v. Ohio: The Capitulation is Complete}

The Warren Court's June 1968 decision in Terry was without a doubt one of the most doctrinally significant developments of the entire criminal procedure revolution. Prior to Terry, the Supreme Court had steadfastly interpreted the Fourth Amendment's reasonableness and warrant clauses in pari materia; that is, in determining whether a search or seizure was reasonable under the Fourth Amendment, the Court would ask whether the state action at issue was supported by probable cause and a warrant. ${ }^{393}$ Although the Court's decisions prior to Terry made clear that the Fourth Amendment's warrant requirement was subject to exception in limited circumstances, never before in the criminal context had the Court recognized an exception to the probable cause requirement. ${ }^{394}$ In fact, the Court's prior decisions

${ }^{390}$ Even conservatives like Richard Nixon agreed that wiretapping should proceed only with prior judicial approval (though at some point he obviously had a change of heart). See Robert B. Semple, Jr., Nixon Decries 'Lawless Society' and Urges Limited Wiretapping, N.Y. TIMES, May 9, 1968, at 1 ("Mr. Nixon strongly endorsed a limited use of wiretapping after a court order showing probable cause.").

Graham, supra note 345, at 32.

392 U.S. 1 (1968).

${ }^{399}$ See Earl C. Dudley, Jr., Terry v. Ohio, The Warren Court, and the Fourth Amendment: A Law Clerk's Perspective, 72 ST. JOHN'S L. REV. 891, 894 (1998) ("The Warrant Clause's standard of 'probable cause' had been taken to define the 'reasonableness' of a search and seizure, even where obtaining a warrant was excused as impracticable.").

${ }^{394}$ See Terry, 392 U.S. at 37 (Douglas, J., dissenting) ("[P]olice officers up to today have been permitted to effect arrests or searches without warrants only when the facts 
had gone the opposite way, stressing the importance of "strictly enforc[ing]" the Warrant Clause's probable cause mandate. ${ }^{395}$ Terry changed all that. In one fell swoop, the Court decoupled the Fourth Amendment's two clauses, recognizing for the first time ever that a search and seizure in the criminal context could be reasonable though based on less than probable cause. If any decision deserves a place among the giants of the criminal procedure revolution, it is Terry v. Ohio.

Traditionally, we in the academy have tended to view Terry as a compromise, a decision that was at least partly responsive to minority concerns at the time. ${ }^{396}$ I myself have taught the case that way, and the

within their personal knowledge would satisfy the constitutional standard of probable cause."). The Court had, however, recognized an exception to the probable cause requirement in the administrative search context in Camara v. Municipal Court, 387 U.S. 523, 538 (1967), a case on which the Terry decision heavily relied. See Terry, 392 U.S. at 20-21 (extending Camera's balancing approach to the criminal context).

${ }^{395}$ In Henry $v$. United States, 361 U.S. 98 (1959), for example, the Court stated:

It is important, we think, that this requirement be strictly enforced, for the standard set by the Constitution protects both the officer and the citizen.... And while a search without a warrant is, within limits, permissible if incident to a lawful arrest, if an arrest without a warrant is to support an incidental search, it must be made with probable cause.

Id. at 102 (citation omitted).

${ }^{396}$ See, e.g., Michael R. Cogan, The Drug Enforcement Agency's Use of Drug Courier Profiles: One Size Fits All, 41 CATH. U. L. REV. 943, 949 (1992) ("The resulting compromise between the needs of law enforcement and the rights of the individual permits the police to make what is commonly referred to as a "Terry stop."); David A. Harris, Frisking Every Suspect: The Withering of Terry, 28 U.C. DAviS L. REV. 1, 12-13 (1994) ("Terry surely represents the Court's best effort to engineer a series of compromises .... On the one hand, police may stop and frisk individuals ... without probable cause. However, an officer must be able to articulate the reasons that she thought that crime was afoot and that the suspect was dangerous."); Scott E. Sunby, A Return to Fourth Amendment Basics: Undoing the Mischief of Camara and Terry, 72 MINN. L. REV. 383, 422 (1988) ("Instead of operating as a general compromise standard as it did in Terry, reasonable suspicion now operates only as a narrow exception to traditional probable cause."); Gregory Howard Williams, The Exclusionary Rule: An Alternative Proposal, 23 CAP. U. L. REv. 229, 234 (1994) ("In Terry, the Supreme Court carved out a very careful compromise which weighed the needs of law enforcement against the right of citizens to be free of undue harassment by the police."); Gregory Howard Williams, The Supreme Court and Broken Promises: The Gradual But Continual Erosion of Terry v. Ohio, 34 How. L.J. 567, 577 (1991) ("The general principles of Terry, explicitly the compromise of balancing relative interests of law enforcement and individual privacy...."); see also Susan Bandes, Terry v. Ohio in Hindsight: The Perils of Predicting the Past, 16 ConsT. COMMENT. 491, 492 (1999) ("But before reviewing all the possible interactions, let's examine the choices before the Supreme Court in 1968. Terry $v$. Ohio was widely viewed as a compromise."). This is not to deny that many commentators see Terry as a distinctly pro-law enforcement decision as well. See, e.g., POWE, supra note 12, at 406 (arguing that "Terry was at least as significant a victory for the police as Miranda had been for the accused"); UROFSKY, supra note 34, at 164 (describing Terry as "[o]ne of 
Court's opinion in Terry easily lends itself to such an interpretation. ${ }^{397}$ According to this "compromise view," the Supreme Court in Terry was faced with two diametrically opposed views of the so-called "stop and frisk" practice at issue in that case. On one hand, police were claiming that a stop was not a seizure under the Fourth Amendment and a frisk was not a search, the result being that the Fourth Amendment did not speak to the practice of stop and frisk at all-i.e., police could do as they liked. On the other hand, the defendant and various civil liberties advocates were claiming that a stop was a seizure and a frisk was a search, the result being that the Fourth Amendment's Reasonableness Clause required both to be supported by no less than probable cause. Given those alternatives, the theory goes, the Supreme Court's decision in Terry split the baby and gave a little something to everyone: the Fourth Amendment did apply to stop and frisk practices, but the probable cause standard did not. Because a stop was not an arrest and a frisk was not a full-blown search, both were constitutionally permissible so long as they were supported by a reasonable, articulable suspicion that criminal activity was afoot and the suspect could be armed and dangerous. ${ }^{398}$

As a theoretical proposition, the Supreme Court in Terry did in fact have both options presented by the compromise view of the decision. Conceivably, the Court could have found the Fourth Amendment inapplicable to stop and frisk practices or applied it with full force. In reality, however, Terry was not the compromise decision we

the most 'pro[-]police' decisions of the Warren Court"); G. EDWARD WHITE, EARL. WARREN: A PUBLIC LIFE 277 (1982) (describing Warren's vote to affirm in Terry as "a considerable bow in the direction of law enforcement"); Tracey Maclin, Terry v. Ohio's Fourth Amendment Legacy: Black Men and Police Discretion, 72 ST. JOHN's L. REV. 1271, 1309 (1998) (describing Terry as "a victory for the police").

${ }^{397}$ See Terry, 392 U.S. at 16 ("There is some suggestion in the use of such terms as 'stop' and 'frisk' that such police conduct is outside the purview of the Fourth Amendment because neither action rises to the level of a 'search' or 'seizure' within the meaning of the Constitution."); see also Scott E. Sunby, "Everyman"'s Fourth Amendment: Privacy or Mutual Trust Between Government and Citizen?, 94 ColuM. L. REV. 1751, 1770 n.62 (1994) ("Both Camara and Terry, the cases that opened the door to the reasonableness test, were themselves carefully portrayed as compromise decisions between the government's argument that the Fourth Amendment did not apply at all and the petitioner's argument that a warrant based on traditional probable cause was required.").

${ }^{398}$ To be precise, the Court in Terry never did rule on what would become known as a "Terry stop," nor did it use the "reasonable, articulable suspicion" terminology for which the decision would become famous. For both, one must turn to Justice Harlan's concurrence. See Terry, 392 U.S. at 31-34 (Harlan, J., concurring) (referring repeatedly to "articulable suspicion" and arguing that a frisk is not constitutionally permissible unless officers first have the right to make a forcible stop). 
tend to think it was, for the state of Ohio never advocated the constitutional legitimacy of stop and frisk based on less than a reasonably founded suspicion in the first place. Nowhere in its brief did Ohio claim that stop and frisk was outside the Fourth Amendment's purview; in fact, just the opposite was true. Explaining its position in the case, Ohio stated:

Due regard for the practical necessities of effective law enforcement requires that the validity of brief informal detention be recognized whenever it appears from the totality of the circumstances that the detaining officers could have had reasonable grounds for their action. A founded suspicion is all that is necessary, some basis from which the courts can determine that detention was not arbitrary or harassing. ...

While the rule permitting temporary detention for questioning is operative under circumstances short of probable cause to make an arrest, there must exist some suspicious or unusual circumstances to authorize even this limited invasion of citizens' privacy. ${ }^{399}$

Similarly, the National District Attorneys Association, Americans for Effective Law Enforcement, and the United States, each acting as amicus curiae on Ohio's behalf, argued that a stop and frisk was permissible only when backed by a "reasonable suspicion" of criminal activity and danger to the approaching officer. ${ }^{400}$ In short, no one in Terry was

${ }^{399}$ Brief for Respondent in Opposition for Petition of Certiorari at 15-16, 21, Terry v. Ohio, 392 U.S. 1 (1968) (No. 67), reprinted in 66 LANDMARK BRIEFS, supra note 83, at 381, 403-04, 409 (citation omitted). Ohio's position during oral argument likewise conceded that police conducting stop and frisk were bound by a reasonable suspicion standard. Oral Argument at 22, Terry (No. 67), reprinted in 66 LANDMARK BRIEFS, supra note 83, at 694, 715 (reproducing Ohio's statement that police "'will not be permitted to stop and frisk an individual simply because he has a suspicion-a mere suspicionunless there are reasonable circumstances justifying the frisk'" (quoting State v. Chilton, 32 Ohio Op. 2d 489, 489 (Ohio Ct. Com. Pl. 1964), affd sub nom. Terry)).

${ }^{400}$ The National District Attorneys Association amicus brief conceded that " $[t]$ he use of a constitutional standard less than probable cause to arrest does not require that temporary field detentions and protective patdowns be conducted on police hunches, uncontrollable by judicial scrutiny." Brief for Amicus Curiae National District Attorneys' Association at 32, Terry (No. 67), reprinted in 66 LANDMARK BRIEFS, supra note 83, at 653,684 . The United States's amicus brief was even more to the point, arguing:

The Fourth Amendment guaranty against unreasonable searches is satisfied if the detention is reasonable under the circumstances, which necessarily must vary from situation to situation. This is not to argue that the Fourth Amendment is inapplicable to police conduct fairly described by the term, 'stop and frisk'; rather, it is to say that a lesser showing will meet the constitutional test of reasonableness in the case of a brief detention on the street than in the case of a conventional arrest. If a right of limited detention does exist, we suggest further that a law enforcement officer has the right to pat down the 
arguing that the police ought to be able to stop and frisk at will, so the option of holding stop and frisk practices completely outside the reach of the Fourth Amendment was never seriously on the table to start with.

Recognizing what Terry was not-a compromise-is crucial to understanding what it was: a profoundly pro-law enforcement decision that gave to the police almost all they had asked of the Court, as contemporary newspapers duly noted. ${ }^{401}$ And that understanding of Terry,

suspect's outer clothing in order to determine whether he possesses a weapon, assuming that this step appears reasonably necessary for the detaining officer's self-protection.

Brief for Amicus Curiae United States at 2-3, Terry (No. 67), reprinted in 66 LANDMARK BRIEFS, supra note 83, at 438, 439-40. Similarly, the Americans for Effective Law Enforcement's amicus brief stated:

The law enforcement process which we ask this Court to sustain in the "stop and frisk" cases under consideration is simply this: A police officer may detain pedestrians or motorists in public places, and question them as to their identity and purpose in the particular location, when under the circumstances, such detention and questioning seems appropriate to a prudent police officer-one mindful of his responsibility "to prevent crime and catch criminals" - because reasonable suspicion of criminality has been aroused, although there is not yet probable cause to believe that a crime has been, or is being, committed.

Brief for Amicus Curiae Americans for Effective Law Enforcement at 6, Terry (No. 67), reprinted in 66 LANDMARK BRIEFS, supra note 83, at 499, 507 (citation omitted); see also Brief for Amicus Curiae New York at 3-4, Terry (No. 67), reprinted in 66 LANDMARK BRIEFS, supra note 83 , at $38,540-41$ (arguing for the constitutionality of a New York statute giving police officers the right "to question any individual in a public place where there is a reasonable suspicion that a crime has been committed or is about to be committed," and that the statute properly allowed a frisk of a suspect "only where there are facts upon which to base a reasonable suspicion that the person being questioned is armed and may use his weapon").

${ }^{401}$ See, e.g., Fred P. Graham, High Court Backs Rights of Police to Stop and Frisk, N.Y. Times, June 11, 1968, at 1 (noting that the Court's decision in Terry "gave the police virtually the full range of powers that law enforcement representatives had asked of the Court"); see also Editorial, "Unreasonable" Still Stands, N.Y. TIMES, June 12, 1968, at 46 (opining that Terry "will help persuade policemen that the Court does not lie awake nights dreaming up ways to increase the hazards of their jobs"). In fairness, the Court in Terry stopped short of giving the police all they had asked, as the Court never formally recognized the legitimacy of a stop based on less than probable cause. See Terry, 392 U.S. at 19 n.16 ("We thus decide nothing today concerning the constitutional propriety of an investigative 'seizure' upon less than probable cause for purposes of 'detention' and/or interrogation."). Yet neither did the Court deny the legitimacy of a stop based on reasonable suspicion, as Justice Harlan pointed out in his concurrence. See id. at 32 (Harlan, J., concurring) ("[I]f the frisk is justified in order to protect the officer during an encounter with a citizen, the officer must first have constitutional grounds to insist on an encounter, to make a forcible stop."). If Terry is in any way a compromise, perhaps it is here, in the Court's reticence to formally recognize what its holding implicitly embraced. 
in turn, is key to seeing the Warren Court's dramatic change in attitude toward criminal procedure in the late 1960s, especially when compared to the Court's Miranda decision two years earlier. In Miranda, the Court eschewed its multifactored voluntariness test for judging the admissibility of police-procured confessions in favor of a bright-line rule that gave interrogators more guidance and less control. Implicit in the Court's ruling was a need to curb police discretion, a reflection of the fact that law enforcement could not be trusted at that time. In Terry, by contrast, the Court's reasonable articulable suspicion standard gave the police so much discretion (and reviewing courts so little upon which to judge police conduct) that it is hard to believe that both decisions were written by Chief Justice Warren. ${ }^{402}$ Even the tone of the opinions is notably different. In Miranda, the Court showed no sympathy whatsoever for the difficulties police faced in bringing criminals to justice, while in Terry, the Court's opinion is all but dripping with that concern. ${ }^{403}$ As Bill Stuntz has likewise recognized, "[o]ne cannot read the two opinions without sensing that something in the author's thinking changed between 1966 and 1968." ${ }^{404}$

Given the potential for minority oppression inherent in stop and frisk practices, the contrast between Miranda and Terry is even more stark. In Miranda, racial concerns were just beneath the surface of the Supreme Court's opinion, ${ }^{405}$ but those concerns were miniscule compared to what the Court confronted in Terry. In terms of sheer numbers, harassing street stops posed a much greater problem for blacks than coercive custodial interrogation ever did. ${ }^{406}$ Indeed, those stops were almost exclusively perpetrated on ghetto minorities-not, as civil

402

See Kamisar, supra note 59, at 117 (comparing Terry to Miranda and noting that "the stop-and-frisk cases established such a spongy test, one that allowed the police so much room to maneuver and furnished the courts so few bases for meaningful review, that the [Terry] opinion must have been cause for celebration in a goodly number of police stations").

${ }^{409}$ See William J. Stuntz, Local Policing After the Terror, 111 YALE L.J. 2137, 2152 n.43

(2002) (contrasting Terry and Miranda).

${ }^{404} \mathrm{Id}$.

${ }^{405}$ See supra note 276 and accompanying text (discussing an early draft of the Miranda opinion that couched the problem of coercive interrogation in terms of police brutality against black defendants).

${ }^{406}$ See Maclin, supra note 396, at 1295 (describing the prevalence of street stops in minority communities compared to custodial interrogation). 
rights leader Bayard Rustin pointed out, on Wall Street's well-dressed bankers. $^{407}$

By 1968, the violent ramifications of abusive stop and frisk practices were also well known. While Terry was pending, the National Advisory Commission on Civil Disorders (better known as the Kerner Commission) issued a report assessing the urban riots that had plagued the country for the past several years, concluding:

We have cited deep hostility between police and ghetto communities as a primary cause of the disorders surveyed by the Commission....

Negroes firmly believe that police brutality and harassment occur repeatedly in Negro neighborhoods. This belief is unquestionably one of the major reasons for intense Negro resentment against the police. . . .

... In nearly every city surveyed, the Commission heard complaints of harassment of interracial couples, dispersal of social street gatherings and the stopping of Negroes on foot or in cars without objective basis. ...

Police administrators, pressed by public concern about crime, have instituted such [stop and frisk] patrol practices often without weighing their tension-creating effects and the resulting relationship to civil disorder. $^{408}$

Similarly, the National Crime Commission's 1967 report described stop and frisk practices as "a major source of friction between the police and minority groups," noting that "an integral element in every riot was strain between the police and members of the Negro community." ${ }^{409}$ Thus, by the time the Supreme Court decided Terry, the racially discriminatory aspects of stop and frisk, along with the violence it precipitated, were well documented.

407 See id. at 1280 (discussing Bayard Rustin's comments in a 1967 national survey on police and community relations); see also Fred P. Graham, The Cop's Right (?) to Stop and Frisk, N.Y. TIMES, Dec. 10, 1967, 6 (Magazine), at 44 ("Negroes, particularly young Negro males, are the ones most likely to be stopped and frisked in these casual, pre-arrest encounters between police and passers-by-and Negroes resent the fact."); Zion, supra note 262, at 1 ("Many of the critics have contended that the [Model Code] would most adversely affect Negroes and Puerto Ricans in the big city ghettoes because most investigative arrests would probably be made there ....”).

408 NAT'L ADVISORY COMM'N ON CIVIL DISORDERS, REPORT OF THE NATIONAL ADVISORY COMMISSION ON CIVIL DISORDERS 157-60 (1968).

409 TASK FORCE REPORT ON CRIME, supra note 343 , at 116. 
No doubt, the Supreme Court was aware of stop and frisk's inherent danger of abuse and its role in exacerbating racial tensions. The NAACP had argued the point in its Terry amicus brief, ${ }^{410}$ the Justices' in ternal memoranda show that they had considered it, ${ }^{411}$ and the Terry opinion itself recognized the problem, citing the National Crime Commission's findings. ${ }^{412}$ Yet in the face of clear evidence that police were using stop and frisk to harass minorities, the Supreme Court condoned the practice, breaking from an entire line of established Fourth Amendment jurisprudence to do it. Given Miranda, the Court's decision in Terry was almost unthinkable just two years earlier-and Terry was an "easy" eight-to-one ruling. ${ }^{413}$ Obviously, something had changed, causing the Supreme Court to reevaluate its earlier commitment to protecting minorities from abusive police practices. The question, again, was what.

Because Terry was as much a blow to the civil rights movement as it was a bow to law enforcement interests, ${ }^{414}$ one consideration that

${ }^{410}$ See Brief for Amicus Curiae N.A.A.C.P. Legal Defense and Education Fund at 68, Terry v. Ohio, 392 U.S. 1 (1968) (No. 67), reprinted in 66 LANDMARK BRIEFS, supra note 83 , at 565, 644 (arguing that "[i]f the police and the ghetto dweller view each other with fear, suspicion, often hatred, any enforced stop is a potential source for conflict").

${ }^{411}$ A handwritten letter from Justice Brennan to Chief Justice Warren stated:

I've become acutely concerned that the mere fact of our affirmance in Terry will be taken by the police all over the country as our license to them to carry on, indeed widely expand, present "aggressive surveillance" techniques which the press tell us are being deliberately employed in Miami, Chicago, Detroit + other ghetto cities. This is happening, of course, in response to the "crime in the streets" alarums being sounded in this election year in the Congress, the White House + every Governor's office... It will not take much of this to aggravate the already white heat resentment of ghetto Negroes against the police-the Court will become the scape goat.

Letter from Justice William J. Brennan, Jr., United States Supreme Court, to Chief Justice Earl Warren, United States Supreme Court (Mar. 14, 1968), reprinted in John Q. Barrett, Deciding the Stop and Frisk Cases: A Look Inside the Supreme Court's Conference, 72 ST. JOHN's L. REV. 749, 825-26 (1998).

${ }^{412}$ See Terry, 392 U.S. at 14 \& n.11 (recognizing " $[\mathrm{t}]$ he wholesale harassment by certain elements of the police community, of which minority groups, particularly Negroes, frequently complain" (citing TASK FORCE REPORT ON CRIME, supra note 343, at 183)).

Only Justice Douglas dissented, and he had initially voted with the majority in conference to affirm. See THE SUPREME COURT IN CONFERENCE, supra note 86, at 454 (reproducing Terry conference notes). Justice Douglas apparently remained with the majority until the Court's opinion changed from a probable cause-based analysis to the more general "reasonableness" analysis it ultimately chose. See Barrett, supra note 411, at 838 (discussing Justice Douglas's defection from the majority in the Terry opinion).

${ }^{414}$ See WHITE, supra note 401 , at 277 (describing Warren's position in Terry as "a considerable bow" in favor of law enforcement interests). 
warrants mention is the nation's waning support for civil rights in the late 1960s. With the rise of urban riots, the public image of black Americans changed dramatically over the course of just a few years. By the late 1960 s, people no longer saw blacks as peaceful, praying protesters being savagely beaten by white policemen, but as lawless looters shouting "[b]urn, baby, burn" while exiting broken storefront windows with all they could carry. ${ }^{415}$ The emergence of militant groups like the Black Panthers in late 1966 and radical civil rights leaders like H. "Rap" Brown in 1967 only reinforced this image as shouts of "black power" replaced pleas for black suffrage and racial hate became the topic du jour on the evening news. ${ }^{46}$ By early 1968 , many Americans who had supported the civil rights movement in earlier years no longer did, resulting in what one columnist described as a "decisive, almost sudden shift" away from the movement's popular backing. ${ }^{417}$ At the very least, the Supreme Court's decision in Terry was consistent with that shift, echoing the country's loss of empathy for the plight of blacks in the late 1960s.

Even so, the Supreme Court's decision in Terry almost certainly had more to do with the nation's desire for "law and order" than its growing disillusionment with the cause of civil rights. By early 1968, crime and lawlessness were all that the nation could think about. ${ }^{418}$ Then came one last spasm of violence that would help give the "turbulent 1960s" its name. On April 4, 1968, Martin Luther King, Jr. was assassinated, setting off riots in over one hundred cities across the nation, including Washington, D.C., where federal troops guarded the

${ }^{415}$ See EDSALl \& EDSALL, supra note 12, at 49-50 (discussing the change in public perception of blacks due to urban riots); TASK FORCE REPORT ON CRIME, supra note 343 , at 116 ("The riots changed the attitude of some Americans toward the civil rights movement from sympathy to antipathy."). This is not to say that urban riots were the only factor contributing to the decline of support for civil rights in the mid- to late$1960 \mathrm{~s}$, only that it was $a$ factor-and a very salient one at that.

${ }_{416}$ See EDSALL \& EDSALL, supra note 12, at 58-59 (noting the formation of the Black Panthers in October 1966 and subsequent decline in Northern, white support for the civil rights movement); PowE, supra note 12, at 277-78 (discussing the ascendancy to power of $\mathrm{H}$. "Rap" Brown and its alienating effect on the civil rights movement).

${ }^{417}$ Herbers, supra note 339 , at E3. Congressional activity during this time reflected the shift perfectly. In 1965, the Voting Rights Act sailed through both houses, whereas in July 1967, the House refused to pass President Johnson's modest proposal for rat extermination funding in urban ghettos, dubbed a "civil rats bill" by conservatives. See MATUSOW, supra note 133, at 215 (discussing bill and unsympathetic mood of Congress in 1967).

${ }^{418}$ See supra notes 333-339 and accompanying text (noting the salience of the crime problem in late 1967 and early 1968). 
White House and set up a machine gun post on the Capitol's front steps. ${ }^{419}$ Over the course of the following week, nearly fifty people across the country would die in connection with racial disturbances while another 21,000 would be charged with riot-related crimes. ${ }^{420}$ The following month, student radicals at Columbia University seized five campus buildings for days, culminating in a bloody confrontation between students and police that led to over two hundred injuries, seven hundred arrests, and the suspension of classes for the remainder of the spring semester. ${ }^{421}$ And as if that were not enough, June 6 , 1968, marked the assassination of presidential contender Robert F. Kennedy, just days before the Court announced its Terry decision. ${ }^{422}$

For those of us who were still in diapers in 1968 (or perhaps just a twinkle in our fathers' eyes), it is difficult to imagine how crazy the world must have appeared at that time. Without the benefit of hindsight, one would have thought the nation was truly coming apart at the seams. Not surprisingly, most Americans surveyed in mid-1968 said law enforcement had "broken down" ${ }^{423}$-and that was before anyone knew about 1968's $16 \%$ rise in the crime rate, a record for the decade. ${ }^{424}$ Naturally, the nation's unrest put immense pressure on the Court to support law enforcement, which by then had made a comeback in public esteem. ${ }^{42}$

419 See CRAY, supra note 59, at 493-94 (discussing the riots in the wake of Martin Luther King's assassination in 1968); MATUSOW, supra note 133, at 396 (same). The United States Army was also dispatched to Chicago and Baltimore. Id. at 396.

${ }^{420}$ See Matusow, supra note 133, at 396 (describing the riots in the wake of Martin Luther King's assassination in 1968); RICE, supra note 96, at 48 (same).

${ }^{421}$ See RICE, supra note 96, at 48 (mentioning the Columbia University incident); WHITE, supra note 326, at 219-20 (same).

${ }^{422}$ Robert Kennedy was shot on June 4, 1968, and died on June 6; Terry was announced on June 10. Barrett, supra note 411 , at $758 \mathrm{n} .29$.

${ }^{423}$ In June, $1968,53 \%$ of those surveyed agreed with the statement that " $[1]$ aw enforcement has broken down in this country, and lawlessness has taken over," while $38 \%$ disagreed and $9 \%$ were unsure. Louis Harris and Associates, Harris Survey (June 16, 1968), WL USHARRIS 061668 R2C 013. In August, the percentage of those agreeing with that statement had risen to $81 \%$. See Public Opinion Online, Accession No. 0174711 , Question \#012 (Harris Survey, Aug. 24, 1968).

${ }^{424}$ See Fed. Bureau of InVestigation, U.S. DeP'T of Justice, Uniform Crime REPORTS FOR THE UNITED STATES-1968, at 4 (1969) (reporting a $16 \%$ increase in the crime rate in 1968),

${ }^{425}$ See Schumach, supra note 324 , at 1 (noting the "great change from public skepticism of the police position"). For a provocative discussion of how television portrayals of police from the 1950s to the 1970 s reflected the public's changing perception of law enforcement, see Steven D. Stark, Perry Mason Meets Sonny Crockett: The History of Lawyers and the Police as Television Heroes, 42 U. MIAMI L. REv. 229 (1987). 
Yet the Supreme Court in Terry must have felt pressure to support law enforcement in general, and stop and frisk in particular, for other reasons as well. By 1968, the Court had come under heavy fire for its pro-defendant criminal procedure rulings, which, according to presidential candidate Richard Nixon, were responsible for the breakdown of "law and order" in the first place. ${ }^{426}$ Moreover, while Terry was pending, Congress debated and passed legislation purporting to reverse Miranda's holding - a clear signal to the Court that public resentment over its previous efforts to regulate police conduct was running high. ${ }^{427}$ Additionally, the National Crime Commission's 1967 report and the ALI's 1966 draft Model Code had both recommended the enactment of stop and frisk laws that would authorize policecitizen encounters based on reasonable suspicion, more as an effort to codify existing practices than to inspire legislative innovation. ${ }^{428}$ Stop and frisk based on reasonable suspicion had been a standard law enforcement practice since at least $1942,{ }^{429}$ and by 1968 , it had become "a matter of routine in every major police department in the country." ${ }^{430}$ Thus, for a number of reasons, Justice Douglas' observation in his Terry dissent was undoubtedly right: the Court was under "powerful hydraulic pressures ... to water down constitutional guarantees

${ }^{426}$ See supra note 323 and accompanying text (discussing Nixon's anti-Court campaign rhetoric).

${ }_{427}$ See supra notes 327-28 and accompanying text (discussing the Omnibus Crime Control and Safe Streets Act of 1968).

${ }^{428}$ See MOdel CODE OF PRE-ARRAIGNMENT Procedure $\$ 2.02$ (Tentative Draft No. 1, 1966) (discussing stop and frisk issue); NAT'L CRIME COMM'N REPORT, supra note 382 , at 95 (same).

${ }^{429}$ The Uniform Arrest Act of 1942 provided:

'A peace officer may stop any person abroad who he has reasonable ground to suspect is committing, has committed or is about to commit a crime ... .

$\ldots$

A peace officer may search for a dangerous weapon any person whom he has stopped or detained to question ... whenever he has reasonable ground to believe that he is in danger....'

Sam B. Warner, The Uniform Arrest Act, 28 VA. L. REV. 315, 320-21, 325 (1942) (quoting the Act and discussing its provisions).

${ }^{430}$ Wayne R. LaFave, "Street Encounters" and the Constitution: Terry, Sibron, Peters, and Beyond, 67 MICH. L. REv. 39, 42 (1968); see also Graham, supra note 333, at E8 (describing stop and frisk as "a matter of routine in most communities for years"). By the time the Court decided Terry, six states had enacted stop and frisk laws (the most prominent being New York), and sixteen states and seven courts of appeal had judicially approved of the practice. Brief of National District Attorneys' Association, supra note 400 , at 15, 31-32, reprinted in 66 LANDMARK BRIEFS, supra note 83, at $647,667,683$ 85 . 
and give the police the upper hand" and those pressures had probably "never been greater" than they were in $1968 .{ }^{431}$

Whether the Supreme Court's decision in Terry reflected the Justices' fear of antagonizing public opinion or their genuine concern about the collapse of law and order is, of course, impossible to know. Either way, the timing of Terry's result was no fortuity. As Earl Dudley, Chief Justice Warren's law clerk on the Terry decision, candidly explained:

Individually, the Justices of the Supreme Court may have felt differing degrees of sympathy with the arguments of the police, but collectively they were unwilling to be-or to be perceived as-the agents who tied the hands of the police in dealing with intensely dangerous and recurring situations on city streets.

Again, context matters, and given the context of 1968, it is inconceivable that the Court in Terry would have decided the case any differently than it did. ${ }^{43}$ In Terry, the Supreme Court had the perfect opportunity to play the role of countermajoritarian hero. It chose not to. Instead, the Court capitulated to law enforcement interests, proving true the adage that "courts love liberty most when it is under pressure least. ${ }^{\text {"494 }}$ As much as any landmark decision of the criminal procedure revolution, Terry demonstrates that the Court is a product of its time.

${ }^{431}$ Terry, 392 U.S. at 39 (Douglas, J., dissenting). As Fred Graham reported in the New York Times:

The Supreme Court's decision will be its first comment on "stop and frisk" laws, and the pressures will be strong for it to approve some degree of "frisking." The President's national crime commission and a panel of the American Law Institution have urged widespread enactment of such laws to improve police efficiency. Further, public opinion would be outraged, under present circumstances, if the courts should say states cannot pass laws to let police search dangerous-looking characters who are suspected of committing crimes.

Graham, supra note 333 , at E8.

${ }^{432}$ Dudley, supra note 393, at 893. For an insightful argument that crime rates have played a significant role in the $\mathrm{ebb}$ and flow of criminal procedure protections, see Stuntz, supra note 403.

${ }^{433}$ Others have likewise recognized that the sociopolitical context of the late $1960 \mathrm{~s}$ was extremely hostile to protecting defendant's rights. See, e.g., Kamisar, supra note 59, at 116 (discussing the social upheaval of late 1960s and attributing that upheaval to creating "an atmosphere that was unfavorable to the continued vitality of the Warren Court's mission in criminal cases"); Allen, supra note 25, at 538-39 (arguing that "the most fundamental reason" for the Court's conservatism on matters of criminal justice in the late 1960s was the social and political context at that time).

${ }^{434}$ John P. Frank, Review and Basic Liberties, in SUPREME COURT AND SUPREME LAW 109, 114 (Edmond Cahn ed., 1954). 
By 1968 , the time to protect criminal defendants had passed, and the criminal procedure revolution had come to an end.

\section{CONCLUSION}

By conventional wisdom, the criminal procedure revolution is a perfect example of the Supreme Court playing the role of countermajoritarian hero, protector of those without power, popularity, or political clout. Upon close inspection, however, the revolution's five most celebrated decisions-Mapp, Gideon, Miranda, Katz, and Terryfail to support that view. Only in Mapp and Miranda did the Warren Court even come close to approaching the sort of countermajoritarian decision making we tend to associate with the revolution, and both of those decisions teach us something quite different than conventional wisdom would have us believe. Mapp demonstrates that when entering a new doctrinal area, the Court's actions tend to be supported by favorable sociopolitical conditions and a factual scenario ideally suited for change. Miranda shows that even in its most aggressive decisions, the Court tends to stay well within the parameters of publicly acceptable policy positions. Though the Supreme Court in Mapp and Miranda undoubtedly played the hero, in neither case did it act in the truly countermajoritarian fashion for which it has been credited.

That said, all five landmarks of the criminal procedure revolution do show what we in academia have tended to overlook: the Court's inextricable tie to its historical setting. In the early- to mid-1960s, the nation championed civil rights and fought a war on poverty. It is no coincidence that the Supreme Court's criminal procedure decisions during that period did so too. By the same token, when the consensus supporting defendants' rights collapsed under the weight of riots and skyrocketing crime rates in the late $1960 \mathrm{~s}$, it is hardly surprising that the Court's criminal procedure rulings took a markedly conservative turn toward the cause of "law and order." Simply put, the Court had no inclination to impose significant pro-defendant protections on a country that had lost interest in protecting criminal defendants. Whether the Court was responding to the national mood or merely reflecting it, the point is the same: in all five decisions, the Court moved with the tide of public opinion rather than against it.

In the end, it is only natural that the Warren Court's landmark criminal procedure cases coincided with the prevailing ideology of the times in which they were decided. The Constitution is written in 
broad, sweeping terms. It takes judges to give those terms meaning. ${ }^{495}$ Like it or not, the fact that judges decide cases and interpret the law means that personal perspectives will inevitably make their way into the decision-making process, and so will the social and political currents that shape those perspectives. As such, the Court's capacity for playing a countermajoritarian role is extremely limited-closer, in fact, to zero than the romantic hero we all tend to imagine.

In 1968, Kenneth Pye wrote: "A hundred years from now lawyers will not be amazed by the changes wrought by the Warren Court. They will wonder how it could have been otherwise in the America of the sixties." ${ }^{436}$ It has been just over fifty years since Earl Warren became Chief Justice, but already those words ring true. One need not believe in the Supreme Court as a countermajoritarian hero to defend judicial review, but often we do. We see the Court as impervious to majoritarian pressures when, in fact, nothing could be further from the truth. Time has shown that the Supreme Court is inextricably bound by the historical context in which it operates. We ought to recognize that fact and be more realistic in our approach to judicial review.

${ }^{435}$ See Michael J. Klarman, Fidelity, Indeterminacy, and the Problem of Constitutional Evil, 65 FORDHAM L. REV. 1739, 1752 (1997) ("If most controversial social issues plausibly can be converted into constitutional disputes, and the document's text is indeterminate as to how those disputes ought to be resolved, how do we show fidelity to the Constitution without subjecting ourselves to uncabined judicial rule?"); Levy, supra note 154 , at 7 ("[W] hat counts is not what the Constitution says, because it says so very little; what counts, rather, is what the Supreme Court has said about the Constitution ....").

${ }^{436}$ Pye, supra note 125, at 268. 